\title{
Article
}

Mycosphere

\section{Biodiversity and ecology of lichens of Katmai and Lake Clark National Parks and Preserves, Alaska}

McCune $\mathbf{B}^{1}$, Arup $\mathbf{U}^{2}$, Breuss $\mathbf{O}^{3}$, Di Meglio $\mathbf{E}^{1}$, Di Meglio $\mathbf{J}^{1}$, Esslinger $\mathbf{T L}^{4}$, Magain $\mathbf{N}^{5}$, Miadlikowska $\mathrm{J}^{5}$, Miller $\mathbf{A E}^{6}$, Muggia $\mathrm{L}^{7}$, Nelson $\mathbf{P R}^{8}$, Rosentreter $\mathrm{R}^{9}$, Schultz $\mathrm{M}^{10}$, Sheard $\mathrm{JW}^{11}$, Tønsberg $\mathrm{T}^{12}$ and Walton $\mathrm{J}^{6}$

${ }^{1}$ Department of Botany and Plant Pathology, Cordley 2082, Oregon State University, Corvallis, Oregon 97331 USA

${ }^{2}$ Botanical Museum, Lund University, Box 117, 22100 Lund, Sweden

${ }^{3}$ Naturhistorisches Museum Wien, Botanische Abteilung, Burgring 7, A-1010 Austria

${ }^{4}$ North Dakota State University, Dept. of Biological Sciences \#2715, PO Box 6050, Fargo, ND 58108 USA

${ }^{5}$ Duke University, Dept. of Biology, Box 90338, Durham, NC 27708 USA

${ }^{6}$ National Park Service, 240 W 5th Ave., Anchorage, Alaska 99501 USA

${ }^{7}$ Univ. of Trieste, Dept. Life Sciences, via Giorgieri 10, 34127 Trieste, Italy

${ }^{8}$ Arts and Sciences Division, University of Maine at Fort Kent, Fort Kent, Maine 04743, USA

${ }^{9}$ Biological Sciences, Boise State University, Boise, Idaho 83725 USA

${ }^{10}$ Herbarium Hamburgense, Institute for Plant Science and Microbiology, University of Hamburg, Ohnhorststr. 18, D22609 Hamburg, Germany

${ }^{11}$ Dept. of Biology, University of Saskatchewan, 112 Science Place, Saskatoon, Saskatchewan S7N 5E2 Canada

12 Department of Natural History, University Museum, University of Bergen, Allégt. 41, P.O. Box 7800, N-5020 Bergen, Norway

McCune B, Arup U, Breuss O, Di Meglio E, Di Meglio J, Esslinger TL, Magain N, Miadlikowska J, Miller AE, Muggia L, Nelson PR, Rosentreter R, Schultz M, Sheard JW, Tønsberg T, Walton J 2018 - Biodiversity and ecology of lichens of Katmai and Lake Clark National Parks and Preserves, Alaska. Mycosphere 9(4), 859-930, Doi 10.5943/mycosphere/9/4/10

\begin{abstract}
We inventoried lichens in Lake Clark (LACL) and Katmai (KATM) National Parks and Preserves. We assembled the known information on lichens in these parks by combining field, herbarium, and literature studies. Our results provide baseline data on lichen occurrence that may be used in resource condition assessments, vulnerability assessments, long-term ecological monitoring, and resource management. We report a total of 896 taxa of lichenized fungi from the Parks, adding 889 taxa to the total of seven taxa reported for the Parks by the National Park Service database and including ten new species first published elsewhere. An additional 15 lichenicolous fungi are reported here. Seven non-lichenized fungi associated with young living twigs of particular host species are also included. Sixteen species are new to Alaska, and six species new to North America (Caloplaca fuscorufa, Lecanora leucococca s.l., Ochrolechia brodoi, Protoparmelia memnonia, and Rhizocarpon leptolepis). Four new combinations are made, Cetraria minuscula, Enchylium millegranum var. bachmanianum, Lathagrium undulatum var. granulosum, and Protomicarea alpestris. Additional new species based on collections from the Parks have been described in separate publications.
\end{abstract}

Key words - Alaska Peninsula - Alaska Range - inventory - lichenized fungi - North America 


\section{Introduction}

Lichens are a major component of high latitude ecosystems and are highly sensitive to environmental conditions, including airborne contaminants, substrate chemistry, and climate. Such attributes make them useful indicators of species richness (Bergamini et al. 2005) and air quality, including the estimation of critical loads (Geiser \& Neitlich 2007, Geiser et al. 2010). Although ecologically important, lichens are a poorly known component within the two largest parks of the Southwest Alaska Network (SWAN), one of 32 Inventory and Monitoring Networks of the National Park Service. Ecosystems in southwest Alaska have an uncertain future, facing climate change and potential new resource development, which may be accompanied by increased pollutant loads. The SWAN parks included in this inventory (Katmai National Park and Preserve; Lake Clark National Park and Preserve) occur on the Alaska Peninsula and fall on a convergence zone of arctic, coastal, and amphiberingean floras.

Wilderness areas in the United States are often protected as Class I air quality designations under the Clean Air Act. None of these, however, exists for the Southwest Alaska Network parks. Tuxedni Wilderness, just off the coast of Lake Clark National Park and Preserve, is a Class I area. Routine weekly data collection from a National Atmospheric Deposition Program (NADP) station in King Salmon, Alaska, west of Katmai National Park and Preserve, has occurred since 2013. Samples of the moss, Hylocomium splendens, have been collected at multiple locations in the parks (2009-2012) for nutrient and heavy metal analysis. Given the effectiveness of lichens as indicators of air quality, developing our understanding of lichen diversity, distribution, and abundance within the parks is an important initial strategy for evaluating future air quality issues.

The first known lichen collections on the Alaska Peninsula were by the Harriman Expedition in 1899 (Cummings 1904). This expedition made a brief stop at Kukak Bay and resulted in only five specimens; apparently the primary lichen collector on the trip, William Trelease, did not visit Kukak Bay. More specimens were collected on nearby Kodiak Island.

Neither of the two most comprehensive treatment of Alaska lichens, Krog (1968), Thomson (1984, 1997) contain much information on the base of the Alaska Peninsula. Krog sampled intensively in southeast Alaska and reported many interesting finds from the Aleutian Islands and the Bering Strait region, but has essentially no information on the intervening region.

Thomson $(1984,1997)$ compiled extensive records of Alaskan lichens, but voluminous collecting trips by him and his colleague, George Scotter, did not include the study area. Thus, Katmai and Lake Clark are hardly represented by his distribution maps and poorly represented in regional treatments of lichens.

The most comprehensive community-level study of lichen diversity to date on the Alaska Peninsula was conducted in the Aniakchak caldera, Aniakchak National Monument and Preserve (ANIA; Hasselbach 1995), but this was restricted to macrolichens. Lichen collections in the remaining parks on the Alaska Peninsula have been limited to those from short field trips in Katmai National Park and Preserve (henceforth "Katmai" or KATM), including small collections from Hallo Bay, Lake Brooks, Valley of Ten Thousand Smokes, Hammersly Lake, Kukaklek Lake, and Lake Camp area (Schindler 1990, Berg 2006) and from opportunistic collections and plot-based sampling associated with vegetation monitoring in interior Lake Clark National Park and Preserve (henceforth "Lake Clark" or LACL) and Katmai (Miller et al. 2006, 2010, 2011). A detailed inventory of lichens was also conducted on Chisik and Duck Islands, in the Tuxedni Wilderness, off of the coast of LACL (Talbot et al. 1992), apparently the first major collection effort in the western Cook Inlet region. East and south of the study area Spribille et al. (2010) thoroughly documented lichens of Klondike Gold Rush National Historic Park, which includes sea-level coastal forests and outcrops up to oceanic alpine tundra. North and east of the study area Stehn et al. (2015) listed lichens of the Denali National Park region.

Several species of conservation concern have been found in spruce woodland and open forest at Katmai in recent years (e.g., Erioderma pedicellatum, Hypogymnia pulverata; Nelson et al. 2011) and in woodlands, coastal spruce, and fellfield ridges at Lake Clark (e.g., Hypogymnia pulverata, Cetrelia alaskana). To date, however, most habitats in the parks have not been sampled, 
and comprehensive nonvascular species lists for SWAN parks do not exist. Alpine areas, calcareous outcrops, old-growth forest, and coastal forest were habitats expected to support high species richness, but were underrepresented in the existing collections.

We inventoried lichens at Katmai and Lake Clark with the goals of (1) expanding the list of species known to occur in the parks; (2) compiling a reference collection of voucher specimens and associated habitat data; (3) compiling the associated geospatial data into a geodatabase; and (4) providing supplementary ecological data (e.g., functional groups) to extend the results of the inventories. The last of those was reported separately (Spickerman 2015).

Some of the results of this study have already been reported elsewhere (Sheard et al. 2014, Arup et al. 2015, Fryday \& Tønsberg 2015, Magain et al. 2016, McCune et al. 2016, Sheard 2018, Tønsberg 2018) and more are forthcoming. The purpose of the current publication is to present a comprehensive treatment of the lichens of these parks, bringing together results from all participants.

\section{Study Area}

Katmai and Lake Clark National Park and Preserves (NPPs) lie at the base of the Alaska Peninsula, south and west of Anchorage (Fig. 1). Most visitor use is concentrated in a few areas, specifically bear viewing areas at Brooks Camp and on the coasts of Lake Clark and Katmai NPPs, and at the historic Dick Proenneke's cabin in Lake Clark NPP, leaving much of the remainder of the parks in nearly pristine condition. Combined, the parks and preserves cover about $33,000 \mathrm{~km}^{2}$, with Katmai the slightly larger of the two. Elevations range from sea level to $2318 \mathrm{~m}$ on the summit of Mt. Denison in Katmai, and to 3108 m on Mt. Redoubt at Lake Clark.

This landscape is young, with most of the area having been recently glaciated or covered with volcanic materials. This is "the geographic heart of the active plate margins that generate Alaska's volcanoes and earthquakes" (Connor 2014). Icefields, glaciers, and moraine-dammed lakes are still common in the Aleutian Range. The geology in the Parks is diverse, with both extrusive and intrusive volcanic rocks, sedimentary, and metamorphic rocks. Rare pockets of limestone and marble hold special botanical interest but in most cases are difficult to access.

The volcano Novarupta produced a major eruption in June 1912. Although some portions of the Park were directly and severely altered (Griggs 1922, 1936, Fierstein \& Hildreth 1992, Miller et al. 2012), other areas received only minor amounts of ejecta. The eruption produced $17 \mathrm{~km}^{3}$ of tephra, but winds were such that most went out to sea (Fierstein \& Hildreth 1992). Only a relatively small area of what is now Katmai National Park received more than $50 \mathrm{~cm}$ of tephra. The Valley of the Ten Thousand Smokes has pyroclastic ash flows 30-234 m deep; we did not sample this area because our sampling strategy favored botanically and geologically diverse areas.

The climate ranges from cold oceanic to subcontinental (Table 1). Precipitation comes throughout the year. Summers are short and cool. Mean annual precipitation ranges from about 49 $\mathrm{cm}$ in the more inland low-elevation rain-shadowed areas west of the Aleutian Range, increasing to some unknown amount on higher mountains (PRISM 2009, interpolated data for 1971-2000: about $300 \mathrm{~cm} / \mathrm{yr}$ at highest elevations). Interior, low elevations range from $\sim 35-48 \mathrm{~cm}$; coastal $\sim 110 \mathrm{~cm}$ and to $108 \mathrm{~cm}$ or more on the coast of Cook Inlet on the wetter west side of the Aleutian Range (Boggs et al. 2003 and see Table 1). Snowfall at low elevations ranges from about 1.1-1.3 m/yr. Mean annual maximum daily temperatures for two representative low-elevation stations are $5.4^{\circ} \mathrm{C}$ on the inland side (King Salmon) and $8.9^{\circ} \mathrm{C}$ on the coastal side (Uganik Bay). For the same stations, annual means for daily minima are $-3.4^{\circ} \mathrm{C}$ and $0.8^{\circ} \mathrm{C}$ for the inland and coastal sides respectively (Boggs et al. 2003).

Vegetation in the Parks varies by topography, surficial geology, and climate (Shephard 2000, Miller et al. 2011). Higher elevations have rock and ice barrens and alpine tundra and dwarf shrub tundra (dominated by Ericaceae: Empetrum, Ledum, Vaccinium as well as dwarf or shrub Betula and Salix). Forests, woodlands, and shrublands are common, including dense tall shrublands (Alnus, Betula, Salix), conifer woodlands and forests with relatively short trees (Picea glauca), hardwood forests (Populus, Betula), and tall forests (Picea sitchensis) near the coast. Permafrost is 
sporadic (Jorgenson et al. 2008). Extensive wetlands, with and without woody plants, occupy poorly drained areas.

Table 1 Climate of representative locations in SW Alaska Network National Parks. Climate groups represent clusters of collecting locations. 30-year time period from 1981-2010, provided by the National Climatic Data Center. http://climate.gi.alaska.edu/Climate/Normals

\begin{tabular}{lccccc}
\hline $\begin{array}{l}\text { Climate group } \\
\text { (station) }\end{array}$ & $\begin{array}{c}\text { Mean annual } \\
\text { precipitation, } \\
\mathrm{cm}\end{array}$ & $\begin{array}{c}\text { Mean annual } \\
\text { snowfall, cm }\end{array}$ & $\begin{array}{c}\text { Mean annual } \\
\text { temperature, } \\
{ }^{\circ} \mathrm{C}\end{array}$ & $\begin{array}{c}\text { Mean January } \\
\text { temperature, }{ }^{\circ} \mathrm{C}\end{array}$ & $\begin{array}{c}\text { Mean July } \\
\text { temperature, } \\
{ }^{\circ} \mathrm{C}\end{array}$ \\
\hline $\begin{array}{l}\text { Katmai } \\
\text { (King Salmon) }\end{array}$ & 49.5 & 118.3 & 1.8 & -8.8 & 13.1 \\
$\begin{array}{l}\text { Lake Clark inland } \\
\text { (Port Allsworth) }\end{array}$ & 33.5 & 225.2 & 2.3 & -9.2 & 14.4 \\
$\begin{array}{l}\text { Lake Clark coastal } \\
\text { (Homer AP) }\end{array}$ & 61.7 & 120.4 & 3.7 & -4.0 & 12.6 \\
$\begin{array}{l}\text { Kenai Fjords } \\
\text { (Seward) }\end{array}$ & 186.2 & 163.6 & 4.7 & -2.7 & 13.3 \\
Homer 8 NW & 74.4 & 263.9 & 2.8 & -4.8 & 11.9 \\
\hline
\end{tabular}

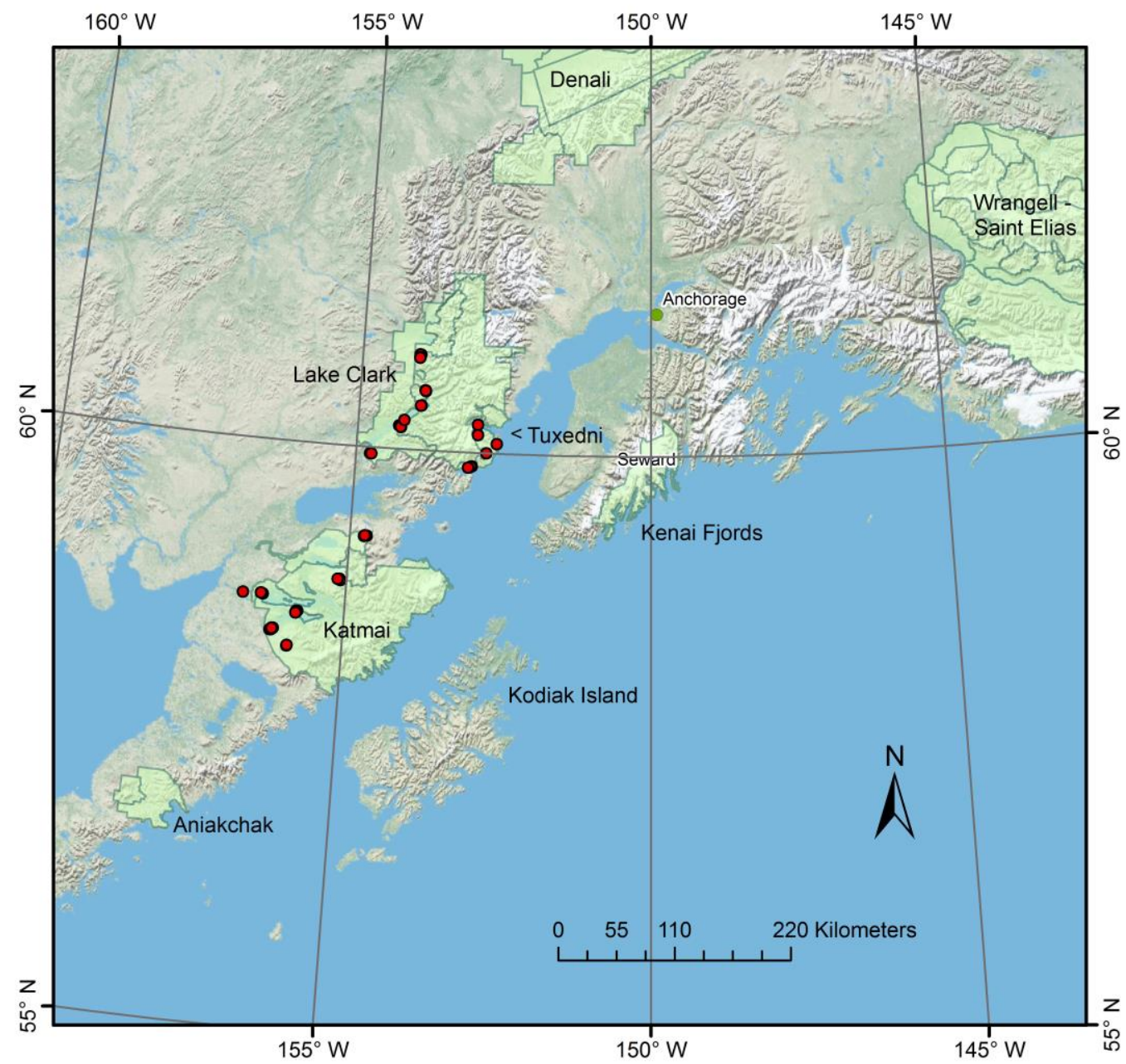

Figure 1 - Study area showing Katmai and Lake Clark National Parks and Preserves in relation to Aniakchak, Kenai Fjords, Denali, and Wrangell-St. Elias National Parks. National Park Service lands are shown in light green. The cities of Anchorage and Seward are indicated. Red dots indicate clusters of sites visited by the lichen team. Nearby Tuxedni Wilderness Area, Alaska Maritime National Wildlife Refuge on Chisik Island was sampled by Talbot et al. (1992). 
The Parks occupy an interesting biogeographic position with a blend of (1) oceanic species typical of the Pacific Northwest, (2) Arctic and boreal species that occur across the continent, and (3) potentially a Beringian element. The relative abundance of these three elements for the Parks is unknown. These parks are far enough north and west that most of the tall conifer species that are characteristic of the Pacific Northwest are unable to survive. In fact, toward the west end of Katmai, we reach the western low-elevation treeline, the limit for both Picea sitchensis and P. glauca, where conifers no longer grow. In these areas the cold oceanic climate apparently does not provide enough heat to for conifers to survive. Westward on the Alaska Peninsula and Aleutian Islands the woody vegetation is restricted to shrubs.

Hultén (1941) considered the base of the Alaska Peninsula to be the Western Pacific Coast District. Dividing this more finely, according the Nowacki et al. (2010) and the Commission for Environmental Cooperation (2011) ecoregions (Fig. 2), the southeast side of the Aleutian Range in Katmai belongs to the Alaska Peninsula Mountains subdivision of the extreme northwest end of the Marine West Coast Forest ecoregion (Level II), while the northwest side of the Aleutian Range belongs to the Bristol Bay-Nushagak Lowlands (Level III) of the Alaska Tundra ecoregion (Level II). This same ecoregion predominates to the north on the Seward Peninsula. At Lake Clark, the southeast side of the Aleutian Range belongs to the Alaska Range portion (Level III) of the Boreal Cordillera (Level II). This ecoregion arcs north and east of Lake Clark. The northwest side of the Aleutian Range in Lake Clark mostly belongs to the Interior Forested Lowlands and Uplands (Level III) of the Alaska Boreal Interior ecoregion (Level II). Lake Clark is near the southern tip of this ecoregion, which occupies a large area of interior Alaska.

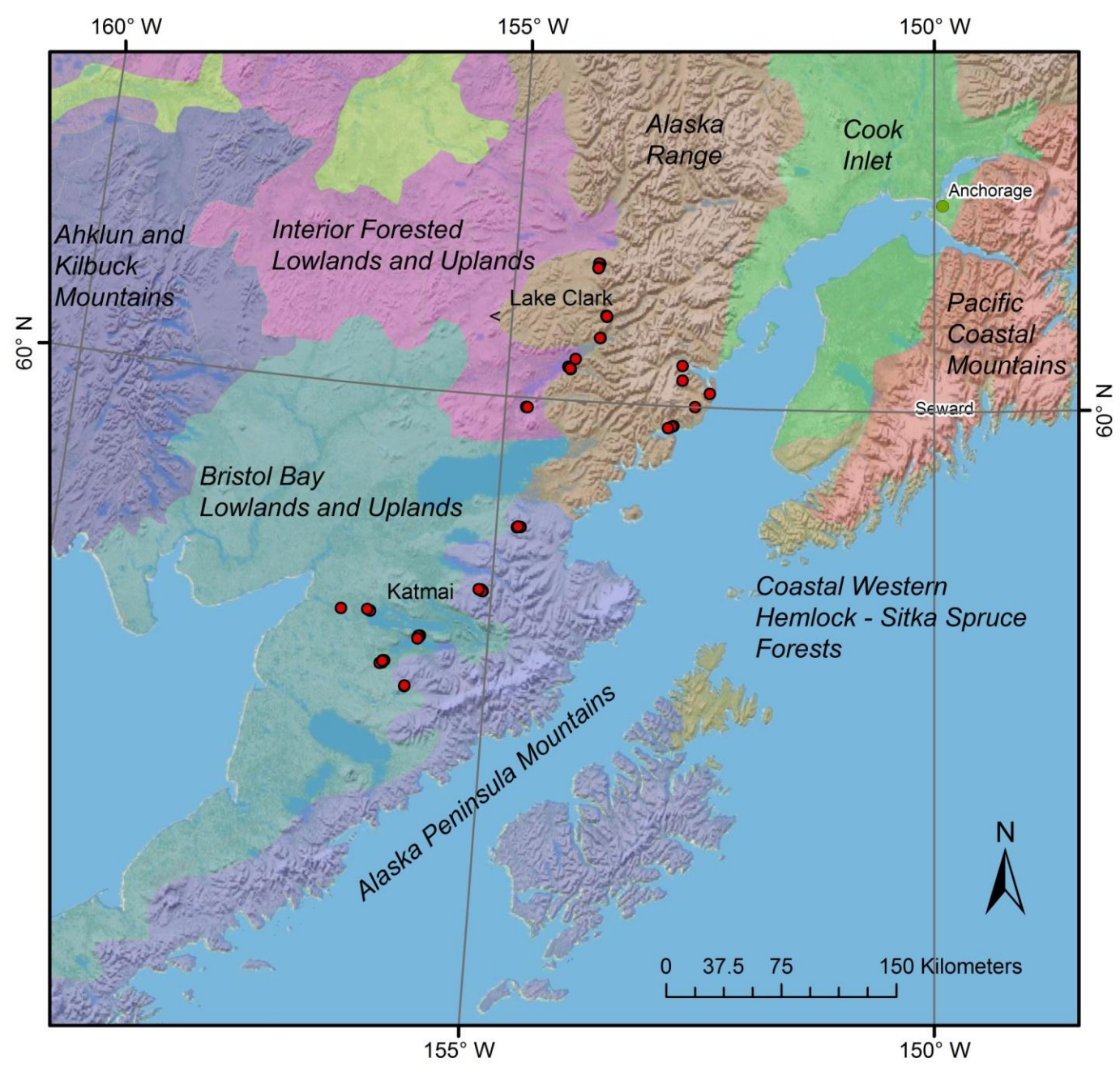

Figure 2 - Ecoregions of Nowacki et al. (2010). Red dots indicate clusters of sites visited by the lichen team. 
We expected that our data would allow us to answer several biogeographic questions about the Parks:

1. How many and which species characteristic of the northwest coastal forests have penetrated the more boreal interior in the rainshadow of the Aleutian Range?

2. Conversely, which boreal and circumarctic species penetrate to the oceanic side of the Aleutian Range?

3. What are the floristic affinities of the alpine tundra?

4. How strongly is the Beringian element expressed in the Parks, and is it noticeably better represented in the more western sites?

\section{Methods}

We evaluated existing collections for Katmai, Lake Clark, and surroundings (e.g., within 50 $\mathrm{km}$ ); identified habitat gaps in the data; and conducted field inventories to fill the gaps. A review of the existing literature (relevant regional publications, taxonomic keys) and nonvascular data sets for the SWAN parks was used to prepare a list of known and expected taxa for each unit.

We used subjective judgment to focus new surveys in areas where high diversity is expected. This method maximizes rapid discovery of species diversity and is relatively cost-effective, but sacrifices park-level quantitative inference. Field observers and laboratory examiners included diverse taxonomic specialists to maximize the reliability and representativeness of important taxonomic groups. Data sources, including literature and new observations, are summarized in Table 2.

Our sampling design met the following criteria: (1) sampling occurred across an elevation gradient, from sea level to alpine, (2) sampling occurred in a range of habitats, and (3) voucher specimens were collected at each site, except for common macrolichens, unless precluded by low population size. Geologic maps, landcover maps and satellite imagery were used to identify accessible areas meeting those criteria.

Sites at Katmai and Lake Clark (Appendix 1) were visited by McCune, Nelson, Rosentreter (Lake Clark only), Spickerman (Katmai only), Tønsberg, and Walton. Each collector focused on particular groups of lichens. Other authors contributed by examining specimens within their specialty. In addition to the sites visited by the group, we include many collections made by James Walton and Amy Miller as part of their vegetation studies in the Parks. Last, because Tuxedni National Wildlife Refuge is so close to Lake Clark, and because Tuxedni is the only nearby area whose lichens have been studied in some detail, many of those specimens (WIS) were re-examined and verified or updated.

Many specimens were subjected to thin-layer chromatography (TLC) by various participants. In general, TLC protocols followed according to the methods of Culberson \& Kristinsson (1970), Culberson (1972), and the later modification by Culberson \& Johnson (1982), All three solvent systems were used (A, B' and C) in most cases by Tønsberg. McCune used B' and C for Lecideaceae s.l. and Cladonia; A and B' for Umbilicaria, and A and C for most other genera. Glass plates were used by Tønsberg to allow for the possible detection of fatty acids. Chemistry is reported when TLC results were available and the information is significant, either in separating the species from its relatives, in validating the species report, or in supplementing the known information about a species.

DNA sequences were obtained for selected critical specimens and for many collections in particular groups, especially Teloschistaceae, small cyanobacterial lichens, Peltigera, Stereocaulon, and Umbilicaria. Various protocols were followed, differing by laboratory, as described in previous publications by various authors of this paper Arup, Magain, McCune, Miadlikowska, and Schultz.

The primary set of voucher specimens is housed in Fairbanks, Alaska (ALA), with portions of the collection housed at other herbaria through loan agreements between institutions and the National Park Service. 
Table 2 Lichen data sources for Katmai and Lake Clark National Parks and Preserves. Numbers of collections include only those identified to species. Appendix 2 lists the number of collections by each collector in each park. NPS = National Park Service.

\begin{tabular}{|c|c|c|c|c|c|}
\hline Source & Katmai & $\begin{array}{l}\text { Lake } \\
\text { Clark }\end{array}$ & Nearby & Identified by & Notes \\
\hline $\begin{array}{l}\text { SWAN vouchers, coll. } \\
\text { by NPS }\end{array}$ & 1631 & 1069 & - & $\begin{array}{l}\text { Walton }+ \\
\text { some by } \\
\text { lichen group }\end{array}$ & $\begin{array}{l}\text { NPS and Walton databases; specimens } \\
\text { at NPS in Anchorage }\end{array}$ \\
\hline $\begin{array}{l}\text { Lichen team } 2013 \text { and } \\
2014\end{array}$ & 1374 & 1991 & - & Group & $\begin{array}{l}\text { Access database for all new } \\
\text { observations transferred to NPS }\end{array}$ \\
\hline $\begin{array}{l}\text { NPS Southwest Area } \\
\text { Network long-term } \\
\text { vegetation monitoring }\end{array}$ & 34 & 61 & - & $\begin{array}{l}\text { Field ID by J. } \\
\text { Walton \& A. } \\
\text { Miller }\end{array}$ & $\begin{array}{l}\text { NPS Monitoring Program database } \\
\text { (most not included here because based } \\
\text { on field identifications) }\end{array}$ \\
\hline $\begin{array}{l}\text { NPS nunatak } \\
\text { monitoring (Miller et } \\
\text { al. 2006) }\end{array}$ & - & 46 & - & $\begin{array}{l}\text { T. Goward \& } \\
\text { C. Björk }\end{array}$ & $\begin{array}{l}\text { Specimens entered in database but not } \\
\text { verified. Vouchers in ALA }\end{array}$ \\
\hline Cahalane (1959) & 6 & & & V. Cahalane & \\
\hline Dillman (2003) & - & 19 & - & $\begin{array}{l}\text { K. Dillman, } \\
\text { K. Glew }\end{array}$ & $\begin{array}{l}\text { Specimens at WTU or NPS in } \\
\text { Anchorage }\end{array}$ \\
\hline Schindler (1990) & 68 & - & - & H. Schindler & $\begin{array}{l}\text { Added to Access database from } \\
\text { publication rather than specimens; } \\
\text { specimens in KR) }\end{array}$ \\
\hline $\begin{array}{l}\text { Harriman Expedition } \\
\text { (Kukak Bay, near } \\
\text { Katmai; specimens in } \\
\text { MO, NY and } \\
\text { elsewhere; Cummings } \\
\text { 1904) }\end{array}$ & - & - & 5 & C. Cummings & $\begin{array}{l}\text { Collected by Kincaid, Coville, and } \\
\text { Kearney. Partially in CNALH; lichen } \\
\text { names in Cummings (1904) are in a } \\
\text { broad sense, difficult to apply here }\end{array}$ \\
\hline $\begin{array}{l}\text { Consortium of North } \\
\text { American Lichen } \\
\text { Herbaria (CNALH) }\end{array}$ & 6 & 4 & 22 & various & $\begin{array}{l}\text { Few in the Parks; not verified, therefore } \\
\text { not included here }\end{array}$ \\
\hline Talbot et al. (1992) & 0 & 0 & 479 & $\begin{array}{l}\text { J. W. } \\
\text { Thomson }\end{array}$ & $\begin{array}{l}\text { All specimens from Tuxedni are at } \\
\text { WIS, and excluded from CNALH total; } \\
\text { many records checked by us }\end{array}$ \\
\hline $\begin{array}{l}\text { Gunther }(1986,1987 a \\
\text { 1987b) }\end{array}$ & - & - & - & A. J. Gunther & $\begin{array}{l}\text { Names used in broad sense; not verified } \\
\text { and not included in database }\end{array}$ \\
\hline NPLichen & 7 & 0 & 0 & V. Cahalane & $\begin{array}{l}\text { Katmai records are based on Cahalane } \\
\text { reports; not duplicated in database }\end{array}$ \\
\hline Totals & 3126 & 3190 & 506 & & \\
\hline
\end{tabular}

\section{Results \& Discussion}

Results are organized as follows. First, we list noteworthy records, including ten species new to science from our collections but formally described elsewhere, new records for North America, and new records for Alaska. Second, we describe potential factors influencing lichen biodiversity in the study area. Third we present new combinations and briefly discuss the rationale for each. Finally, we list all taxa known from the study area, annotated with notes on abundance, substrate, and collection details for selected taxa. 


\section{Noteworthy Records}

\section{New Taxa}

Leptogium compactum (Stone et al. 2016)

Leptogium cookii (Stone et al. 2016)

Parvoplaca nigroblastidiata (Arup et al. 2015)

Physconia labrata (Esslinger et al. 2017)

Rhizocarpon isidiatum (Tønsberg et al. 2018)

Rhizocarpon quinonum McCune, Timdal \& Bendiksby (McCune et al. 2016)

Rinodina incurva Sheard \& J. Walton (Sheard 2018)

Rinodina pallidescens Sheard \& Tønsberg (Sheard et al. 2014)

Umbilicaria dura McCune (McCune 2018)

Umbilicaria multistrata McCune (McCune 2018)

New to North America

Caloplaca fuscorufa

Lecanora leucococca s.l.

Ochrolechia brodoi (Brodo \& McCune 2017)

Protoparmelia memnonia

Rhizocarpon leptolepis

Rhizocarpon sinense

New to Alaska (This list is only tentative, since we do not have a current comprehensive list for Alaska)
Aspicilia bicensis
Aspicilia sipeana
Calicium parvum
Calicium trabinellum
Chaenothecopsis epithallina
Chaenotheca phaeocephala
Fuscidea intercincta
Lecanora laatokkaensis
Lecanora pringlei
Rhizocarpon oederi
Rinodina badiexcipula
Rinodina colobina
Rinodina milvina
Rinodina willeyi
Sclerophora coniophaea
Varicellaria lactea
Zahlbrucknerella fabispora

Listed Species in Alaska. Of the 64 lichen species currently listed as "rare" by the Alaska Center for Conservation Science (AKNHP 2015), we found 30\% (19) in the two parks. Of these, 15 were found in Katmai and 16 in Lake Clark.

\section{Potential factors influencing lichen biodiversity}

We observed a lichen flora with a mix of arctic-alpine, boreal, and coastal elements. The Beringian element, which is evident on the Seward Peninsula and Aleutian Islands, was not prominent at either Katmai or Lake Clark. 
Many oceanic forest species were found at low elevation moist sites in both Katmai and Lake Clark, especially in the forest along Chinitna Bay. Some of those penetrate to the interior of the Alaska Range, but the vegetation is notably more circumboreal there.

Although we visited some great alpine sites with well-developed late-successional vegetation, certain species groups or genera were surprisingly rare in Katmai NP. These include the alpine ground-dwelling Rinodina species such as R. olivaceobrunnea, ground-dwelling Hypogymnia, and Dactylina. These genera were somewhat more abundant at Lake Clark than at Katmai, but still not as abundant as in more continental climates and the Rocky Mountains. Potential contributing factors include tephra deposition from volcanism or climate, which could have extirpated local populations. In particular deep, late-melting snowpacks, at least in some years, could contribute to differences between this more oceanic tundra of southwest Alaska, and the more interior and cordilleran tundra of the Rockies.

Nitrophilous species (e.g., Caloplaca, Xanthoria) appear to be very sparse in both parks, suggesting low levels of nitrogenous pollutants. We also encountered very few calciphiles, owing to the predominantly acidic rocks in both Parks.

Although we were unable to sample on limestone or dolomite in Katmai, we did visit one site with marble on the shore of Lake Clark. Many calciphilic species were found at that site, complementing the flora of more acidic rocks in the surrounding areas. Despite the young landscape, many calciphiles have been able to "find" this island of calcium carbonate in a sea of volcanic rock. These include Circinaria contorta, Enchylium polycarpon, E. tenax, Endocarpon pusillum, Placidium squamulosum, Psora decipiens, P. himalayana, and Synalissa ramulosa.

The heavily glaciated landscape of these two parks might be expected to host unusual species compositions and higher diversity in nunataks - ridges and peaks projecting above the ice sheets. Vegetation sampling on currently existing nunataks (Miller et al. 2006) revealed a number of rare and disjunct vascular plant species. While that work listed a number of lichen species, it did not attempt a detailed inventory of lichens. We did not sample any modern nunataks; however, at least two of our study sites were possibly historical nunataks when ice fields were more extensive. These are the ridge west of Contact Creek in Katmai National Park, and the slopes and flats above Turquoise Lake in Lake Clark National Park. Both of these sites had relatively high species totals (67 and 133, respectively), despite the absence of trees.

\section{New Combinations}

Cetraria minuscula (Elenkin \& Savicz) McCune comb. nov.

MycoBank number: MB826948

Basionym - Cetraria cucullata f. minuscula Elenkin \& Savicz, Trudy Bot. Muz. Imp. Akad. Nauk 8: 43 (1910).

三Flavocetraria minuscula (Elenkin \& Savicz) Ahti, Poryadina \& Zhurb., Mycotaxon 92: 202 (2005)

Notes - Apparently this combination was inadvertently omitted from the reorganization of cetrarioid lichens by Divakar et al. (2017). Although one would think it would follow Cetraria cucullata into Nephromopsis, a tree by Nelsen et al. (2011) placed it in the Cetraria clade, rather than Nephromopsis.

Enchylium bachmanianum var. millegranum (Degel.) M. Schultz \& McCune comb. nov. MycoBank number: MB826949

Basionym - Enchylium bachmanianum var. millegranum Degel., Symbolae Botanicae Upsalienses 13 (2): 192. 1954.

Notes - Apparently inadvertently omitted from new combinations in Otálora et al. (2014).

Lathagrium undulatum var. granulosum (Degel.) M. Schultz \& McCune comb. nov.

MycoBank number: MB826950 
Basionym - Collema undulatum var. granulosum Degel., Symbolae Botanicae Upsalienses 13 (2): 369. 1954.

Notes - Apparently inadvertently omitted from new combinations in Otálora et al. (2014).

Protomicarea alpestris (Sommerf.) McCune, comb. nov.

MycoBank number: MB823128

Basionym - Lecidea alpestris Sommerfelt, K. norske Vidensk. Selsk. Skr. 2(2.H.):54 (1827).

Notes - As of 2017 MycoBank gave Octospora alpestris (Sommerf.) Dennis \& Itzerott, Kew Bulletin 28(1):10 (1973) as the correct name for Lecidea alpestris, but this appears to have resulted from confusion with the same epithet applied in the Pezizales.

Some discrepancies in reports of chemical content of Lecidea alpestris exist in the literature. According to Thomson (1997), Brodo (1981, p. 524), the species contains pannarin (P+ orange red) and occurs on moss and soil. The $\mathrm{P}+$ red reaction was also noted by Lynge (1940), Magnusson (1952). But the Aptroot et al. (2009) for Great Britain stated that the species is P - and occurs on siliceous rock.

This "rare circumpolar arctic-alpine" species (Thomson 1997) has been reported from Colorado and southern Alaska, as well as Greenland and the northeast American Arctic. It is most likely to be mistaken for a Micarea or because of its immarginate apothecia, reduced exciple, and substrate of soil, plant detritus, and bryophytes. More details are provided in McCune (2017, p. 344).

Three new ITS sequences (McCune 34126, 35257, 35383; GenBank MH579752, MH579753, MH579754) analyzed with a selection of related genera suggest that this species belongs to Protomicarea. Also sequenced were two specimens of P. limosa from Alaska (McCune 32954, 36351; GenBank MH579751, MH579755). The apothecial anatomy is nearly the same as $P$. limosa, but the two species are easily distinguished by the longer spores in Lecidea alpestris. Protomicarea Hafellner (Stapfia 76: 156 (2001)) was erected and persisted as a monotypic genus until a second species was added here. See comparison and key to Protomicarea and related species in McCune (2017, p. 536).

Rostania occultata var. populina (Th. Fr.) Perlmutter \& Rivas Plata

MycoBank number: MB827051 [Note: removed new combination in proof because it appeared elsewhere.]

Basionym - Collema verruciforme f. populinum Th. Fr., Nova Acta Regiae Societatis Scientiarum Upsaliensis 3: 379. 1861.

Synonym - Collema occultatum var. populinum (Th. Fr.) Degel., Symbolae Botanicae Upsalienses 13 (2): 245.1954.

Notes - Apparently inadvertently omitted from new combinations in Otálora et al. (2014).

\section{Annotated List of Taxa}

The following list of taxa is annotated by substrate, frequency of occurrence, and taxonomic notes. Results are separated by park (Katmai, Lake Clark, and nearby Tuxedni; Tables 3, 4). If neither park is listed, comments refer to both parks. Some of the Tuxedni records (Talbot et al. 1992, specimens in WIS) have been verified. Revisions of Tuxedni material or confirmation of interesting finds is also included in our list.

Voucher specimens are split among the NPS herbarium in Anchorage, the University of Alaska in Fairbanks (ALA), and on loan to collector's home institutions. Muggia collection numbers have had the prefix "LM-KATM" removed.

For the most part generic placement follows the most recent North American checklist. Exceptions include cases where generic splits are not well supported by the data or where authors have treated only some of the species from our region, making our species difficult to assign to genera. 


\section{Locality Information}

Detailed locality information is given for the group sites (Appendix 1) and for specimens of particular interest. See abbreviations in Table 4. Other locality data are available from the first author or the NPS Southwest Alaska Network office in Anchorage.

Table 3 Symbols and number of taxa reported for different kinds of records.

\begin{tabular}{|c|c|l|}
\hline $\begin{array}{c}\text { Number } \\
\text { of taxa }\end{array}$ & $\begin{array}{c}\text { Symbol } \\
\text { in list }\end{array}$ & Type of record \\
\hline 896 & none & $\begin{array}{l}\text { Lichenized, accepted name, accepted record from within or } \\
\text { immediately adjacent to Katmai and Lake Clark National Parks } \\
\text { and Preserves }\end{array}$ \\
\hline 15 & $\dagger$ & Nonlichenized, lichenicolous \\
\hline 7 & $\dagger \dagger$ & $\begin{array}{l}\text { Nonlichenized, nonlichenicolous, but traditionally treated with } \\
\text { lichens }\end{array}$ \\
\hline 6 & - & $\begin{array}{l}\text { Not yet known from Katmai or Lake Clark, but expected based on } \\
\text { records at Tuxedni National Wildlife Refuge and nearby area }\end{array}$ \\
\hline 4 & $?$ & Questionable record \\
\hline 8 & $\times$ & Name valid but probably not at Katmai or Lake Clark \\
\hline
\end{tabular}

Table 4 Abbreviations of commonly used references.

\begin{tabular}{|l|l|}
\hline Abbreviation & Reference \\
\hline CNALH & $\begin{array}{l}\text { Consortium of North American Lichen Herbaria } \\
\text { (http://lichenportal.org/portal/) }\end{array}$ \\
\hline Katmai & Katmai National Park and Preserve \\
\hline Lake Clark & Lake Clark National Park and Preserve \\
\hline NPLichen & $\begin{array}{l}\text { Database of lichens in the U.S. national parks (www.nbii.gov/nplichen; } \\
\text { NPLichen 2011) }\end{array}$ \\
\hline NPS & National Park Service \\
\hline Tuxedni & Tuxedni Wilderness Area, Alaska Maritime National Wildlife Refuge \\
\hline
\end{tabular}

\section{Abundance ratings}

Abundance ratings are based on our experience and limited sampling. Abundance ratings are necessarily subjective, and are not given when there is little basis for doing so. For example, a single occurrence of an inconspicuous species may represent an overlooked common species or a truly rare species. The more conspicuous a species, the easier it is to state an abundance.

The following frequency classes are applied:

- very common (> 40 collections)

- common (10-40 collections)

- occasional (3-10 collections).

- uncommon to rare or otherwise noteworthy collections are listed individually

Acarospora sp. undescribed - Lake Clark: Tanalian Falls SE of Port Alsworth, on vertical rock wall, Rosentreter 18484, det. Knudsen 2015. "I only know of one other taxon with globose spores this small in the family and it is on wood and is morphologically related to Caeruleum heppii." (Knudsen pers. comm. to Rosentreter Nov 2015).

Acarospora fuscata (Schrader) Arnold - Lake Clark: slopes and flats above Turquoise Lake, on rock, McCune 34985.

Acarospora sinopica (Wahlenb.) Körber - Lake Clark: shoulder of mountain overlooking Tuxedni Bay, on metal rich rock, Tønsberg 44275.

Acarospora superfusa H. Magn. - Katmai: shoreline of Naknek Lake on peninsula NE of Brooks 
Camp, on rock, McCune 32785.

Agonimia allobata (Stizenb.) P. James - Lake Clark: campsite at NW end of Turquoise Lake, on bark, McCune 35043.

$\dagger$ Agyrium rufum (Pers.) Fr. - Lake Clark: Chinitna Ranger Station north side of Chinitna Bay, on wood, beach log, McCune 35670.

Ahlesia sphaerospora (H. Magn.) G. Salisb. - Lake Clark: Clam Cove, on sandstone cliff, Dillman 2003-1245, det. K. Glew 2003 (Dillman 2003).

Alectoria nigricans (Ach.) Nyl. - Common on humus, on tundra sod, and rock. Previously segregated from Alectoria as Gowardia nigricans (Ach.) P. Halonen et al., but now considered part of Alectoria, based on applying a consistent temporal phylogenetic criterion within the Parmeliaceae (Divakar et al. 2017).

Alectoria ochroleuca (Hoffm.) A. Massal. - Common on humus or humus over rock.

Alectoria sarmentosa (Ach.) Ach. - Occasional on conifer bark and wood. Katmai: Brooks Camp; SW of Malone Lake; Coville Lake. Lake Clark: Chinitna Ranger Station.

Allantoparmelia alpicola (Th. Fr.) Essl. - Common on rock.

Alyxoria varia (Pers.) Ertz \&Tehler - Lake Clark: shore of Lake Clark, stop 2, W of Hatchet Point, on base of dead trunk of Populus balsamifera, Tønsberg 44130.

Amandinea sp. - Lake Clark: bay on SW side of Portage Lake, on wood and bark, twigs of Picea glauca, Tonsberg 43920; campsite at NW end of Turquoise Lake, on base of twigs of Salix (shrub), Tфnsberg 43813.

Amandinea cacuminum (Th. Fr.) H. Mayrhofer \& Sheard - Lake Clark: near outlet of Turquoise Lake, on lakeshore boulder, McCune 35094.

Ameliella andreaeicola Fryday \& Coppins - Katmai: ca. $200 \mathrm{~m}$ N of Mirror Lake camp, Thnsberg 42838 (Fryday \& Tønsberg 2015; also reported by them from Kenai Fjords National Park).

Amygdalaria consentiens (Nyl.) Hertel, Brodo \& Mas. Inoue - Katmai: ca. $200 \mathrm{~m} \mathrm{~N}$ of Mirror Lake camp, on rock, McCune 34048b; low rocky ridge NE of Mirror Lake, Muggia 152, 145. Lake Clark: shoulder of mountain overlooking Tuxedni Bay, on metal-rich rock, McCune 35488; Slope Mountain overlooking Tuxedni Channel, McCune 35374 (det. Brodo 2016). Some specimens have dark reddish brown apothecia and chemistry (stictic acid) of var. japonica Mas. Inoue, but Brodo \& Hertel (1987) did not think this deserved taxonomic recognition.

Amygdalaria continua Brodo \& Hertel - Katmai: Shoreline near camp on north side of Mirror Lake, on boulder on beach, McCune 34012.

Amygdalaria elegantior (H. Magn.) Hertel \& Brodo - Lake Clark: slopes and flats above Turquoise Lake, on rock, McCune 34989, 35028, 35027a, 35002.

Amygdalaria panaeola (Ach.) Hertel \& Brodo - Common on rock, exposed to partial shade.

Amygdalaria pelobotryon (Wahlenb.) Norman - Occasional on rock, low elevations to alpine.

Amygdalaria subdissentiens (Nyl.) Mas. Inoue \& Brodo - Occasional on rock, low elevations to alpine.

Anaptychia bryorum Poelt - Occasional on rock, low elevations, especially lakeshores.

Arctomia interfixa (Nyl.) Vainio - Katmai: Ridgetop W of Contact Creek, Tфnnsberg 42874. Spores needle-shaped, (6)7-septate, 41-47 × 6-7 $\mu \mathrm{m}$.

Arctoparmelia centrifuga (L.) Hale - Occasional on rock.

Arctoparmelia incurva (Pers.) Hale - Katmai: ca. $1 \mathrm{~km} \mathrm{SW}$ of Malone Lake, on granite boulder, McCune 34174, Walton 18851; NE of Cucumber Lake, partial shade, mesic, rock outcrop, Walton 13022. Lake Clark: Turquoise Lake, on rock, McCune 35066.

Arctoparmelia separata (Th. Fr.) Hale - Lake Clark: occasional on humus over rock. Katmai: alpine ridge above Hammersly Lake, on rock, Spickerman 200.

Arctoparmelia subcentrifuga (Oksner) Hale - Lake Clark: Camel's Hump on shore of Lake Clark ca. $10 \mathrm{~km}$ NE of Port Alsworth, on rock and moss, Rosentreter 18778.

Arthonia sp. - Occasional on Alnus, Betula, and Salix.

Arthonia radiata (Pers.) Ach. - Lake Clark: Chinitna Ranger Station, on Alnus, McCune 35560. 
Arthonia vinosa Leighton - Lake Clark: Chinitna Ranger Station, on Picea, McCune 35571c, 35570.

Arthopyrenia sp. - Katmai: ca. $200 \mathrm{~m}$ N of Mirror Lake camp, on Salix by stream, McCune 34057.

Arthopyrenia analepta (Ach.) A. Massal. - Lake Clark: shore of Chinitna Bay, ca. $3 \mathrm{~km}$ ENE of Chinitna Ranger Station, on twig, Alnus, McCune 35659.

Arthrorhaphis sp. nov. - Katmai: NW shore of Malone Lake, on soil, peaty bank, McCune $34208 a$. Arthrorhaphis alpina (Schaerer) R. Sant. - Occasional on moss and humus over rock, more frequent in Lake Clark. Katmai: Ridgetop W of Contact Creek, Tønsberg 42876 (fertile).

Arthrorhaphis citrinella (Ach.) Poelt - Katmai: Ridgetop W of Contact Creek, on bryophytes over rock, Spickerman 240 (thallus section without calcium oxalate crystals). Lake Clark: south end of Pickerel Lake, on soil, steep bank by lake, McCune 35677.

Asahinea chrysantha (Tuck.) Culb. \& C. Culb. - Common on humus and rock.

Asahinea scholanderi (Llano) Culb. \& C. Culb. - Occasional on humus and rock.

Aspicilia sp. - Katmai: alpine ridge above Hammersly Lake, on rock, bird perch, McCune 32945; isidiate but K-.

Aspicilia sp. - Lake Clark: shore of Lake Clark, W of Hatchet Point, on lakeshore outcrops, McCune 35353 (thallus brown with sessile lecanorine apothecia, medulla $\mathrm{K}+$ red, spores 13-17 $\times$ 8-10 $\mu \mathrm{m}$; paraphyses moniliform in $\mathrm{K}$; epithecium brownish olive; ITS sequence falls in unnamed clade near A. cinerea, T. Wheeler unpublished tree).

Aspicilia aquatica Körber - Occasional on streamside and freshwater beach rocks, low elevations to alpine, apparently more frequent in Lake Clark. Some or all of these specimens may be $A$. aff. indissimilis (below).

Aspicilia bicensis F. Anderson \& Lendemer - Katmai: shoreline of Naknek Lake on peninsula NE of Brooks Camp, on noncalcareous rock, Muggia 012a, 018, 023b (all det. McCune via ITS sequences; GenBank MH579756, MH579757, MH579758; Fig. 3). The trimmed ITS region differs in four positions from that of the type specimen in GenBank, and in one position among the Alaskan sequences. This species was only recently described (Anderson \& Lendemer 2016) and was previously known from only the type locality along the St. Lawrence River in eastern Canada (Quebec). Based on these two records that span the continent, we hypothesize that the species occurs across North America or is circumboreal. That material from Quebec is sterile, but one of our three specimens $(012 a)$ is fertile, from which we provide the following description. Apothecia embedded in the tops of strongly convex areoles, 1-2 per areole, becoming sessile or slightly stipitate; disk blackish, to $0.8 \mathrm{~mm}$ diameter; excipular ring sometimes present, brownish gray to dark brown; amphithecial cortex distinct, 25-35 $\mu \mathrm{m}$ thick, brownish olive at upper edge, otherwise hyaline, POL- in outer part, POL+ in a thin layer adjacent to the algal layer; medulla thick, POL+; epithecium olive green to olive brown; parathecium expanded at the surface, brownish at upper edge, hyaline below, weakly POL+; hymenium about $120 \mu \mathrm{m}$ thick; paraphyses submoniliform in water; asci mostly partially abortive, with $2-8$ spores; ascospores $18-22 \times 10-13 \mu \mathrm{m}$; apothecial section with $\mathrm{K}+$ yellow diffusion then forming red crystals (norstictic acid); pycnidia were not found. Associates on specimens from the Alaskan site include Phaeophyscia sciastra, an unknown Aspicilia species (fertile), and Rhizocarpon sinense. The two sterile Alaskan specimen differ from the fertile one in having a very thick thallus (to several $\mathrm{mm}$ ) composed of tightly massed, stalked, heavily sorediate areoles. In contrast, the fertile specimen has scattered strongly convex to substipitate areoles with only weakly developed soredia. The form of the soralia is variable, sometimes pustular as described by Anderson and Lendemer, sometimes nonpustular with cortex grading into soredia, and sometimes confluent as a continuous powdery mass across the top of the stalked areoles.

Aspicilia caesiopruinosa (H. Magn.) J. W. Thomson - Katmai: shoreline of Naknek Lake on peninsula NE of Brooks Camp, on noncalcareous rock, Muggia 010 (det. McCune, fitting description in Thomson (1997, p. 66).

Aspicilia cinerea (L.) Körber - Occasional on rock, low elevation to alpine. 
Aspicilia confusa Owe-Larsson \& A. Nordin - Katmai: shoreline of Naknek Lake on peninsula NE of Brooks Camp, on noncalcareous rock, McCune 32772, 32774.

Aspicilia cf. cyanescens Owe-Larsson \& A. Nordin - Lake Clark: bay on SW side of Portage Lake, on rock, wetted lakeshore boulder, McCune 35142; outlet of Turquoise Lake, on boulder in depression, McCune 35106b; sandstone boulder on saltwater shoreline, McCune 35630; Tanalian Falls, on rock, McCune 34905. Some or all of these specimens may be A. aff. indissimilis (below).

Aspicilia elevata (Lynge) J. W. Thomson - Katmai: shoreline of Naknek Lake on peninsula NE of Brooks Camp, on noncalcareous rock, McCune 32773 (areoles tiny, crowded, brownish gray; apothecia developing raised dark proper margin, finally becoming sessile; spores $17-22 \times$ 8-12 $\mu \mathrm{m}$; epithecium olive; paraphyses moniliform).

Aspicilia aff. indissimilis (H. Magn.) Räsänen - Lake Clark: Pickerel Lake, SW end, on beach rocks, amphibious, McCune 36003. ITS sequence: unnamed clade near A. indissimilis, T. Wheeler tree, unpublished, 2017.

Aspicilia cf. intermutans (Nyl.) Hue - Katmai: N end of ridge W of Contact Creek (alpine), on rock, McCune 34103. ITS sequence placed in T. Wheeler unpublished tree, 2017.

Aspicilia sipeana (H. Magn.) Owe-Larss. \& A. Nordin - Lake Clark: Tanalian Falls, on rock, McCune 34908. New to Alaska.

Aspicilia supertegens Arnold - Lake Clark: near campsite at NW end of Turquoise Lake, on lakeshore rock, McCune 35056 (thallus grayish white; epithecium olive green, $\mathrm{K}+$ yellow diffusion; spores 26-27 × 15-16 $\mu \mathrm{m}$; paraphyses moniliform in $\mathrm{K}$; spermatia 20-22 $\mu \mathrm{m}$ long; ITS sequence with close match in GenBank to Nordin 6023).

Athallia holocarpa (Hoffm.) Arup, Frödén \& Søchting - Occasional on rock, especially freshwater lakeshores.

Athallia vitellinula (Nyl.) Arup, Frödén \& Søchting - Lake Clark: Camel's Hump on shore of Lake Clark, on rock in cavity facing lake at inner edge of lakeshore beach, Tфnsberg 44083 (det. Arup 2016).

Bacidia bagliettoana (A. Massal. \& De Not.) Jatta - Katmai: near NW shore of Malone Lake, on soil, peaty bank, McCune 34207.

Bacidia circumspecta (Nyl. ex Vainio) Malme - Katmai: near shore of Naknek Lake, N of Brooks Camp, on Populus bark, McCune 32761.

Bacidia subincompta (Nyl.) Arnold - Not yet known from Katmai and Lake Clark, but reported and confirmed from Tuxedni: Chisik Island, on Populus trichocarpa, Talbot 87014-2A, 1381Q, 88052-Y-10, Talbot 88052-V-12.

Bacidia sp. - Katmai: alpine ridge above Hammersly Lake, on rock, McCune 32932. Thallus areolate, gray; apothecia convex, brown to black; spores acicular, 40-52 × 1.5-2.1 $\mu \mathrm{m}$; apothecial section nearly hyaline except for brownish spots in upper hymenium and pale brownish upper hypothecium.

Bacidina circumpulla Ekman \& Spribille ined. - Lake Clark: near SW end of Pickeral Lake, on dead Alnus viridis, Tonsberg 44012.

Bacidina sp. - Lake Clark: shoulder of mountain overlooking Tuxedni Bay, on Alnus viridis, Tonsberg 44247.

Baeomyces carneus Flörke - Katmai: Ridgetop W of Contact Creek, on moss over rock, Spickerman 66 (thallus K+R, UV+ weak white, norstictic crystals; sterile). Lake Clark: slopes and flats above Turquoise Lake, on moss hanging on boulder, Tønsberg 43776; trail to Tanalian Falls from Port Alsworth, on soil, Rosentreter 18473. Tuxedni: Chisik Island, low herb snowbed, on soil, Talbot 810 .

Baeomyces placophyllus Ach. - Occasional on humus or more often on mineral soil, apparently more frequent in Lake Clark.

Baeomyces rufus (Hudson) Rebent. - Common on mineral soil, frost boils, bear trails, and moss over rock.

Bellemerea alpina (Sommerf.) Clauzade \& Cl. Roux - Lake Clark: slopes and flats above 
Turquoise Lake, on rock, McCune 34987; summit of Slope Mountain, overlooking Tuxedni Channel, on argillite, McCune 35414.

Bellemerea cinereorufescens (Ach.) Clauzade \& Cl. Roux - Katmai: N of Mirror Lake camp, on rock, streamside noncalcareous boulder, McCune 34030; on rock, Muggia 174. Lake Clark: shoulder of mountain overlooking Tuxedni Bay, on metal-rich rock, McCune 35490 (orangebrown iron-stained thallus, TLC with unknown Rf B'5 C5; DNA sequence: ITS KY800500; ver. by T. Wheeler by comparison with his sequences); same location, Tønsberg 44274 (TLC: unidentified substance A4, B'5, C5; fatty acids). Lake Clark: summit of Slope Mountain, overlooking Tuxedni Channel, on argillite, McCune 35415.

Bellemerea diamarta (Ach.) Hafellner \& Cl. Roux - Katmai: ca. $200 \mathrm{~m}$ N of Mirror Lake camp, on rock, McCune 34049.

Bellemerea subsorediza (Lynge) R. Sant. - Lake Clark: bay on SW side of Portage Lake, on rock wall, Tфnsberg 43911; saddle on ridge near headwaters of Johnson River, on rock, HCl-, McCune 35521; shoulder of mountain overlooking Tuxedni Bay, on metal-rich rock, McCune $35484 a$, on loose rock on small shelf in rock wall, Tфnsberg 44255, 44257.

Biatora aegrefaciens Printzen - Katmai: shore of Naknek Lake, bay just N of Brooks Camp, on Salix, McCune 32875. Lake Clark: trail between Port Alsworth and Tanalian Falls, on twigs of Picea glauca, Tonsberg 43723; Tanalian Falls, on twigs of Picea glauca, Tonsberg 43675.

Biatora albohyalina (Nyl.) Bagl. \& Carestia - Katmai: Near Brooks Camp, S of Brooks River, on bark of dead Alnus, Thnsberg 42574 (sterile; with pycnidia); midslope below ridge above

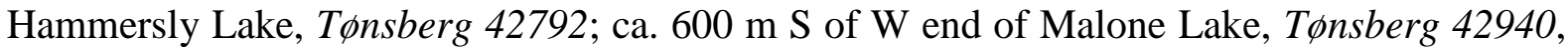
42951. Lake Clark: on dead Alnus viridis, Tonsberg 44030; Tanalian Falls, on trunk of nearly dead Salix on top of small hillock, Tфnsberg 43688. Tuxedni: Chisik Island, Populus trichocarpa forest, on Populus trichocarpa, Talbot 88052-V-12b.

Biatora efflorescens (Hedl.) Räsänen - Common on bark, especially at Lake Clark, on Betula, Alnus viridis, and Salix, rarely on wood (Picea glauca).

Biatora flavopunctata (Tønsberg) Hinteregger \& Printzen - Common on subalpine shrubs, especially Alnus viridis.

Biatora kodiakensis Printzen \& Tønsberg - Occasional, especially on Alnus viridis.

Biatora meiocarpa var. tacomensis (Printzen \& Tønsberg) Printzen \& Tønsberg - Lake Clark: shoulder of basin on E side of Saddle Mountain, on Alnus viridis in thicket at alpine shrub limit, Tonsberg 44177. Tuxedni: Chisik Island, low herb snowbed, on Alnus crispa, Talbot 842 (original det. Lecidea cinnabarina in Talbot et al. 1992).

Biatora oligocarpa Printzen \& Tønsberg - Lake Clark: near mouth of Horn Creek E of Chinitna Ranger Station, on lichens on Populus, including Parmeliella triptophylla, McCune 35613. Tuxedni: Chisik Island, on Alnus crispa and Sorbus scopulina, Talbot 88063-X-8, Talbot 88063-Y-2 (both original det. Biatora vernalis by Thomson in Talbot et al. 1992).

Biatora pallens (Kullhem) Printzen - Katmai: near shore of Naknek Lake, N of Brooks Camp, on Populus, McCune 32762. Lake Clark: Tanalian Falls, on twigs of Picea glauca, Tфnsberg 43676; near SW end of Pickeral Lake, on dead trunk of Betula neoalaskana just above lakeshore beach, Tonsberg 43988.

Biatora rufidula (Graewe) S. Ekman \& Printzen - Katmai: near Brooks Camp, S of Brooks River, along road and trail toward viewing platforms, on twigs of Picea glauca, Tonsberg 42624; near shore of Naknek Lake, N of Brooks Camp, on twigs of Picea glauca, Tonsberg 42633a; ca. $300 \mathrm{~m} \mathrm{~S}$ of W end of Malone Lake, corticolous on dead Salix, Tønsberg 42921 (with Biatora albohyalina). Lake Clark: Chinitna Ranger Station, on Picea twig, McCune 35578, 35597; inland from beach meadow, on twigs, Tonsberg 44322.

Biatora subduplex (Nyl.) Printzen - Katmai: on Populus balsamifera, moss over bark, Walton 18652, det. Ulf Arup 2014; N of Mirror Lake camp, on Salix, McCune 34056; on twig of Picea glauca, Tфnsberg 42851. Lake Clark: saddle on ridge near headwaters of Johnson River, on tundra sod, McCune 35514.

Biatora toensbergii Holien \& Printzen - Lake Clark: shoulder of mountain overlooking Tuxedni 
Bay, on Alnus viridis in dense thicket, Tonsberg 44259; Chinitna Ranger Station, on Alnus viridis inland from beach meadow, Tonsberg 44298.

Biatora vacciniicola (Tønsberg) Printzen - Occasional on Alnus, Betula, and Salix, especially lakeshores and subalpine.

Biatora vernalis (L.) Fr. - Lake Clark: trail to Tanalian Falls from Port Alsworth, on organic matter, Rosentreter 18458 (det. McCune).

Blastenia ammiospila (Ach.) Arup, Søchting \& Frödén - Occasional on driftwood, moss over rock, and shrub bases (most specimens det. Arup 2016).

Brianaria sylvicola (Flotow) S. Ekman \& M. Svensson - Lake Clark: shoulder of mountain overlooking Tuxedni Bay, on rock, ephemeral snowmelt stream, McCune 35499. Lake Clark: slopes and flats above Turquoise Lake, on shaded and sheltered, loose rocks on the ground, Tønsberg 43785 (only purple pigment observed in the hypothecium; TLC: no substances).

Brodoa oroarctica (Krog) Goward - Lake Clark: slopes and flats above Turquoise Lake, on boulder, McCune 34976, Rosentreter 18529.

Bryobilimbia diapensiae (Th. Fr.) Fryday, Printzen \& S. Ekman - Katmai: alpine ridge above Hammersly Lake, on Diapensia, McCune 32904.

Bryobilimbia sp. - Lake Clark: saddle on ridge near headwaters of Johnson River, on dead moss over gravelly soil, McCune 35506. The ITS sequence for this specimen blasts in Bryobilimbia. The thallus is indistinct and the apothecia convex, black, Micareoid in appearance.

Bryocaulon divergens (Ach.) Kärnefelt - Common on humus, soil, and alpine sod.

Bryonora castanea (Hepp) Poelt - Lake Clark: saddle on ridge near headwaters of Johnson River, on tundra sod, McCune 35515.

Bryonora curvescens (Mudd) Poelt - Katmai: N end of ridge $\mathrm{W}$ of Contact Creek, on moss (Andreaea) over rock, McCune 34104. Lake Clark: bay on SW side of Portage Lake, on lakeside cliff, Tønsberg 43930; slopes and flats above Turquoise Lake, on moss on layer of humus on rain-exposed rock, Tønsberg $43789 c$.

Bryoplaca sinapisperma (Lamarck) Søchting, Frödén \& Arup - Lake Clark: saddle on ridge near headwaters of Johnson River, on tundra sod, McCune 35513.

Bryoplaca tetraspora (Nyl.) Søchting, Frödén \& Arup - Lake Clark: near outlet of Turquoise Lake, on tundra sod, McCune 35112.

Bryoria americana (Motyka) Holien - Common in near-coastal areas on conifers.

Bryoria bicolor (Ehrh.) Brodo \& D. Hawksw. - Lake Clark: summit of Slope Mountain, overlooking Tuxedni Channel, Rosentreter 18817.

Bryoria capillaris (Ach.) Brodo \& D. Hawksw. - Occasional on conifer branches.

Bryoria fuscescens (Gyelnik) Brodo \& D. Hawksw. - Occasional on conifers, Betula, and Salix, rarely on alpine sod; includes specimens that would previously have been recognized as Bryoria chalybeiformis (L.) Brodo \& D. Hawksw. Also includes forms previously assigned to Bryoria lanestris (Ach.) Brodo \& D. Hawksw.

Bryoria implexa (Hoffm.) Brodo \& D. Hawksw. - Katmai: near National Park Service bunkhouse in King Salmon, on bark, Picea twigs, McCune 32706. Lake Clark: low ridge above inlet stream to Pickerel Lake, on bark, Picea twigs, Rosentreter 18662.

Bryoria nitidula (Th. Fr.) Brodo \& D. Hawksw. - Occasional on rock, soil, and alpine sod.

Bryoria pseudofuscescens (Gyelnik) Brodo \& D. Hawksw. - Common on conifers.

Bryoria simplicior (Vainio) Brodo \& D. Hawksw. - Common on conifers and Betula, rarely on rock.

Buellia abstracta (Nyl.) H. Oliv. - Katmai: shoreline of Naknek Lake, peninsula NE of Brooks Camp, Muggia 015b.

Buellia aethalea (Ach.) Th. Fr - Katmai: alpine ridge above Hammersly Lake, on rock, Muggia 049; ca. 600 m north of Mirror Lake camp, Muggia 192b. Lake Clark: near campsite at NW end of Turquoise Lake, on rock, loose on gravel flats, McCune 35088 (all det. McCune).

Buellia alboatra (Hoffm.) Th. Fr - Katmai: shoreline of Naknek Lake, peninsula NE of Brooks 
Camp, Muggia 038, Tфnnsberg 42704b (closely associated with Lecanora dispersa s.l.; TLC: no substances).

Buellia coniops (Wahlenb.) Th. Fr. - Katmai: ca. 600 m north of Mirror Lake camp, Muggia 192a, 193, 202 (det. McCune).

Buellia disciformis (Fr.) Mudd - Occasional on Alnus, Salix, and Sorbus.

Buellia erubescens Arnold - Occasional on Alnus, Betula, and Salix.

Buellia griseovirens (Turner \& Borrer ex Sm.) Almb. - Katmai: near shore of Naknek Lake, N of Brooks Camp, Tønsberg 42686. Lake Clark: Chinitna Ranger Station, on Alnus viridis inland from beach meadow, Tønsberg 44212, 44304; 250 m NE of Chinitna Bay Ranger Station, near site of prehistorical pit houses, on decaying Alnus viridis, Tonsberg 44415. Two chemotypes were found by TLC, 42686: atranorin, norstictic acid, pigment(s); 44304, 44417: atranorin, pigment. Squash preparation with K of 44415 yielded red needle-like crystals indicative of norstictic acid.

Buellia insignis (Naeg. ex Hepp) Th. Fr. - Katmai: NE side of Malone Lake, on Picea twig, McCune 34216.

Buellia punctata (Hoffm.) A. Massal. - Occasional on bark, Alnus and Picea.

Buellia schaereri De Not. - Katmai: ca. $600 \mathrm{~m} \mathrm{~S}$ of W end of Malone Lake, on wood, Picea branches, McCune $34149 \mathrm{~b}$.

Calicium glaucellum Ach. - Lake Clark: 2 Chinitna Bay Ranger Station, on wood, conifer snag, McCune 35662; Nelson 14-100a; SW end of Pickerel Lake, on Picea stump, McCune 35209.

Calicium lenticulare Ach. - Lake Clark: Chinitna Ranger Station, on Picea glauca, Nelson 14-126, on conk, Nelson 14-55; on rotted snag, Nelson 14-101.

Calicium parvum Tibell - Lake Clark: near Chinitna Ranger Station, Nelson 14-100b.

Calicium salicinum Pers. - Katmai: S shore Naknek Lake near $1.3 \mathrm{~km} \mathrm{~S}$ of Gull Island, on Salix, Nelson 13-110.

Calicium trabinellum (Ach.) Ach - Lake Clark: Chinitna Bay Ranger Station, on conifer snag, McCune 35664b; SW end of Pickerel Lake, on turned old stump near lake shore, Nelson 14424, 14-425; trail to Tanalian Falls from Port Alsworth, on underside of rotten log, Nelson 14-272.

Calicium viride Pers. - Katmai: ca. $600 \mathrm{~m} \mathrm{~S}$ of $\mathrm{W}$ end of Malone Lake, on wood, Picea branches, McCune 34147. Lake Clark: $200 \mathrm{~m} \mathrm{~W}$ of W end of Portage Lake, on base of Picea glauca, Nelson 14-561b; Chinitna Ranger Station, on Picea, McCune 35569b, Nelson 14-103; shore of Lake Clark, W of Hatchet Point, on Picea glauca, Nelson 14-128.

Calogaya arnoldii (Weddell) Arup, Frödén \& Søchting - Lake Clark: Camel's Hump on shore of Lake Clark ca. $10 \mathrm{~km}$ NE of Port Alsworth, on rock, cliff face, McCune $35290 b$.

Caloplaca ahtii Søchting - Katmai: Headwaters Creek, SW of Malone Lake, Tønsberg 43001. Lake Clark: Shore of Lake Clark ca. $30 \mathrm{~km}$ NE of Port Alsworth, W of Hatchet Point, in fissure on trunk of Populus, Tфnsberg 44110 (det. Arup 2016).

Caloplaca approximata (Lynge) H. Magn. - Lake Clark: North shore of Tuxedni River, on granite cliff, Dillman KD 2003-1220 (Dillman 2003).

Caloplaca borealis (Vainio) Poelt - Lake Clark: NE end of Turquoise Lake, corticolous on Salix at upper edge of rocky beach, Tфnsberg 43817a; on \pm flaking bark at base of dead branches of Salix, Thnsberg 43851; near SW end of Pickeral Lake, corticolous on branch/trunk of Alnus viridis just above lakeshore beach, Tфnsberg 43969 (all specimens det. Arup 2016).

Caloplaca caesiorufella (Nyl.) Zahlbr. - Lake Clark: near outlet of Turquoise Lake, on tundra sod, McCune $35111 b$.

Caloplaca cerina (Hedwig) Th. Fr. - Katmai: Kukak Bay, on bark, Kincaid 836a (Cummings 1904).

Caloplaca citrina (Hoffm.) Th. Fr. - Katmai: shoreline of Naknek Lake, peninsula NE of Brooks Camp, on rock, Muggia 026, $028 a$ (det. McCune).

Caloplaca epithallina Lynge - Katmai: shoreline near camp on north side of Mirror Lake, Muggia 188 (det. Muggia). 
Caloplaca exsecuta (Nyl.) Dalla Torre \& Sarnth s.1. - Katmai: Shoreline near camp on north side of Mirror Lake, on boulder on beach, McCune 34023; shoreline of Naknek Lake, peninsula NE of Brooks Camp, Muggia 007a (det. Muggia).

Caloplaca ferruginea (Hudson) Th. Fr. - Tuxedni: Chisik Island, substrate unknown, Talbot 88011-X.

Caloplaca flavovirescens (Wulfen) Dalla Torre \& Sarnth. - Katmai: shoreline of Naknek Lake, peninsula NE of Brooks Camp, Muggia 027, 030 (det. McCune).

Caloplaca fraudans (Th. Fr.) H. Olivier - Lake Clark: north shore of Tuxedni River, on granite cliff, Dillman KD 2003-1222b. In North America the species is restricted to coastal sites in the northeast, leaving western reports ambiguous (Arup 1994).

Caloplaca fuscorufa $\mathrm{H}$. Magn. - Lake Clark: NW end of Turquoise Lake, McCune 35072b (det. Arup; DNA U2147, GenBank MH136559). New to North America.

Caloplaca holocarpa (Hoffm. ex Ach.) A. E. Wade - Katmai: shoreline of Naknek Lake, peninsula NE of Brooks Camp, Muggia 029 (det. McCune).

Caloplaca invadens Lynge - Katmai: shoreline of Naknek Lake, peninsula NE of Brooks Camp, on rock, Muggia $028 b$ (det. McCune).

Caloplaca jungermanniae (Vahl) Th. Fr. - Lake Clark: slopes and flats above Turquoise Lake, on organic matter, Rosentreter 18525.

Caloplaca nivalis (Körber) Th. Fr. - Katmai: north of Mirror Lake camp, on bryophytes on streamside rock, McCune 34039; on streamside noncalcareous boulder, McCune 34027. Lake Clark: shoulder of mountain overlooking Tuxedni Bay, on moss over rock, McCune 35478, Tønsberg 44240.

Caloplaca sorocarpa (Vainio) Zahlbr. - Common on subalpine Alnus and Salix.

Caloplaca stillicidiorum (Vahl) Lynge - Common on various organic substrates including mosses over rock, root wad, tundra sod, caribou bones, and Salix (most specimens det. Arup2016).

Caloplaca tornö̈nsis H. Magn. - Katmai: ca. 200 m N of Mirror Lake camp, on Andreaea on boulder, Tфnsberg 42837 (Fryday \& Tønsberg 2015).

Caloplaca turkuensis (Vainio) Zahlbr. - Lake Clark: NW end of Turquoise Lake, on wood, root wad, McCune 35042; on Salix at upper edge of rocky beach, Tфnsberg 43817b; on branch of dead Salix on vertical soil bank at rocky lakeshore beach, Tonsberg 43835; corticolous at base of hanging, dead branches of Salix on steep slope facing lake, Tфnsberg 43854.

Calvitimela aglaea (Sommerf.) Hafellner - Katmai: ca. $800 \mathrm{~m} \mathrm{~S}$ of W end of Malone Lake, on rock, granite, McCune 34151 (confirmed with ITS sequence); alpine ridge above Hammersly Lake, Muggia 066; Lake Clark: slopes and flats above Turquoise Lake, on rock, McCune 34988, 35018a; summit of Slope Mountain, overlooking Tuxedni Channel, on rock, McCune 35372. Tuxedni: Chisik Island, low herb snowbed, on boulder, Talbot 779.

Calvitimela melaleuca (Sommerf.) R. Sant. - Katmai: low rocky ridge NE of Mirror Lake, Muggia 168 (det. McCune).

Candelaria concolor (Dickson) Stein - Lake Clark: bay on SW side of Portage Lake, on moss, Rosentreter 18625; Telaquana Lake, partial shade, mesic, Picea glauca bark, Walton 18868, det. Walton 2013.

Candelaria pacifica M. Westberg \& Arup - Lake Clark: near mouth of Horn Creek E of Chinitna Ranger Station, partial shade, mesic, Picea glauca branch, Walton 19154; shore of Lake Clark, W of Hatchet Point, partial shade, mesic, Populus balsamifera bark on bole, Walton 19304.

Candelariella aggregata M. Westberg - Lake Clark: SW side of Portage Lake, on rock, McCune $35167 b$.

Candelariella coralliza (Nyl.) H. Magn. - Lake Clark: shoulder of mountain overlooking Tuxedni Bay, on rock, McCune 35479; slopes and flats above Turquoise Lake, on lichens on rock, McCune 34986. New to western North America.

Candelariella efflorescens R. C. Harris \& W. R. Buck - Tuxedni: Chisik Island; 0.5 miles north of Cannery, Talbot 128-A. 
Candelariella placodizans (Nyl.) H. Magn. - Lake Clark: W end of Turquoise Lake, $\mathrm{N}$ of the outlet, and just inland from beach, on the ground in alpine tundra with dwarf Betula thickets, Tønsberg 43736; asci with 32 or more spores, spores globose to ellipsoid, 7-14 $\times 4.5-6 \mu \mathrm{m}$.

Candelariella vitellina (Hoffm.) Müll. Arg. - Occasional on rock, including bird perches and shaded microsites.

Candelariella sp. - Lake Clark: small drainage on slope above NE side of Turquoise Lake $\mathrm{N}$ of the outlet, and just inland from beach, on caribou antler, Tфnsberg 43801; thallus areolate, esorediate; areoles to $0.4 \mathrm{~mm}$ diam., asci with $>12$ spores.

Carbonea vorticosa (Flörke) Hertel - Katmai: alpine ridge above Hammersly Lake, on rock, McCune 32937. Lake Clark: summit of Slope Mountain, overlooking Tuxedni Channel, on rock, McCune 35394.

Carbonicola anthracophila (Nyl.) Bendiksby \& Timdal - Lake Clark: trail to Tanalian Falls from Port Alsworth, on log, dead conifer, McCune 34939.

Catapyrenium cinereum (Pers.) Körber - Lake Clark: saddle on ridge near headwaters of Johnson River, on soil, gravelly, McCune 35507; above Turquoise Lake, on soil, Rosentreter 18526.

Catapyrenium daedaleum (Kremp.) Stein - Katmai: $3.2 \mathrm{~km}$ N of Hammersly Lake, partial shade, mesic, humus, Walton 13336; trail to Tanalian Falls from Port Alsworth, on soil, Rosentreter 18453. Lake Clark: shore of Lake Clark W of Hatchet Point, on soil, Rosentreter 18788.

Catinaria atropurpurea (Schaerer) Vězda \& Poelt - Katmai: Alluvial flats near camp on E side of Hammersly Lake, Tønsberg 42808; shore of Naknek Lake, N of Brooks Camp, Tønsberg 42663, det. Z. Palice (2014), 42659.

Catinaria neuschildii (Körber) P. James - Lake Clark: SW end of Pickerel Lake, on dead Alnus viridis on steep slope, Tønsberg 44023.

Cecidonia xenophana (Körber) Triebel \& Rambold - Lake Clark: shoulder of mountain overlooking Tuxedni Bay, on metal-rich rock, McCune 35483.

Cercidospora epipolytropa (Mudd) Arnold - Katmai: alpine ridge above Hammersly Lake, on Lecanora polytropa, Muggia 044; shoreline near camp on E side of Hammersly Lake, Muggia 130, Muggia 138. Lake Clark: slopes and flats above Turquoise Lake, McCune 34967.

Cetraria aculeata (Schreber) Fr. - Occasional on soil and humus.

Cetraria commixta (Nyl.) Th. Fr. - Lake Clark: slopes and flats above Turquoise Lake, on rock, Rosentreter 18523, 18536. Tuxedni: Chisik Island, cliff margin, on rock, Talbot 1028.

Cetraria delisei (Bory ex Schaerer) Nyl. - Lake Clark: trail to Tanalian Falls from Port Alsworth, on soil, Rosentreter 18457.

Cetraria ericetorum Opiz, primarily subsp. reticulata (Räs.) Kärnefelt - Occasional on humus, alpine tundra or forest floor.

Cetraria fastigiata (Delise ex Nyl.) Kärnefelt - Common on humus, tundra and woodlands.

Cetraria islandica subsp. crispiformis (Räsänen) Kärnefelt - Very common on organic soil, humus, often in alpine tundra.

Cetraria islandica subsp. islandica (L.) Ach. - Lake Clark: saddle on ridge near headwaters of Johnson River, shaded mesic, alpine tundra, Walton 19113. Outside of Parks: Cabin Bay Porcupine Island, Iliamna Lake, on Rita O'Clair, 1986IL36I.

Cetraria kamczatica Savicz - Very common on humus and alpine sod.

Cetraria laevigata Rass. - Occasional on humus.

Cetraria madreporiformis (With.) Müll. Arg. - Lake Clark: campsite at NW end of Turquoise Lake, on tundra sod, Rosentreter 18578.

Cetraria minuscula (Elenkin \& Savicz) McCune - Katmai: alpine ridge above Hammersly Lake, on soil, Nelson 13-45. Lake Clark: Lime Hills quad, partial shade, mesic, over moss on forest floor, Walton 19093.

Cetraria muricata (Ach.) Eckfeldt - Lake Clark: ridge N of Lachbuna Lake, on rock, Walton 16465,16466

Cetraria nigricans Nyl. - Very common on humus, mineral soil, and humus over rock, often in 
alpine tundra.

Cetraria pinastri (Scop.) Gray - Common on bark and wood of trees and shrubs, mainly at low elevations.

Cetraria sepincola (Ehrh.) Ach. - Common on Betula, less often on Alnus or Picea.

Cetraria tilesii Ach.) - Lake Clark: $61.1379 \mathrm{~N}^{\circ} 153.8533^{\circ} \mathrm{W}, 436 \mathrm{~m}$, on mineral soil, Walton 13570; $60.7527 \mathrm{~N}^{\circ} 153.9806^{\circ} \mathrm{W}, 1187 \mathrm{~m}$, on humus, Walton AEM_2010_126a; shore of Lake Clark, W of Hatchet Point, on soil over rock, McCune 35316, Tønsberg 44123; small drainage on slope above NW side of Turquoise Lake, on alpine sod, McCune 35036.

Cetrelia alaskana (C. Culb. \& Culb.) Culb. \& C. Culb. - Lake Clark: $60.56525^{\circ} \mathrm{N}, 154.23605^{\circ} \mathrm{W}$, full sun, mesic alpine tundra, Walton $15927 ; 60.4794^{\circ} \mathrm{N}, 154.1044^{\circ} \mathrm{W}, 963 \mathrm{~m}$, alpine tundra, Walton 16443.

Chaenotheca brachypoda (Ach.) Tibell - Katmai: S shore Naknek L. near Grandma's Rock about $5.1 \mathrm{~km}$ from boat launch, on Populus balsamifera, Nelson 13-225.

Chaenotheca brunneola (Ach.) Müll. Arg. - Lake Clark: Chinitna Ranger Station, on rotted snag, Nelson 14-100c.

Chaenotheca chrysocephala (Ach.) Th. Fr. - Lake Clark: $250 \mathrm{~m}$ NE of Chinitna Bay Ranger Station, near site of prehistorical pit houses, on conifer snag, McCune 35663.

Chaenotheca furfuracea (L.) Tibell - Common on soil, roots, tree bases, moss over rock, and rock in sheltered sites.

Chaenotheca phaeocephala (Turner) Th. Fr. - Lake Clark: bay on SW side of Portage Lake, on base of Picea glauca, Nelson 14-310, 14-312; SW end of Pickerel Lake, on base of Picea glauca, Nelson 14-269.

Chaenotheca stemonea (Ach.) Müll. Arg. - Lake Clark: $200 \mathrm{~m}$ west of west end of Portage Lake, on base of Picea glauca, Nelson 14-560b; Chinitna Ranger Station, on Picea, Nelson 14-132.

Chaenotheca trichialis (Ach.) Th. Fr. - Common on bases of Picea, less often on Populus balsamifera and underside of old log.

Chaenothecopsis epithallina Tibell - Lake Clark: Chinitna Ranger Station, on Picea, McCune 35571b, Nelson 14-130b.

Chaenothecopsis nana Tibell - Lake Clark: shore of Lake Clark ca. $30 \mathrm{~km}$ NE of Port Alsworth, W of Hatchet Point, on Picea glauca, Nelson 14-127.

Chaenothecopsis tasmanica Tibell - Lake Clark: Chinitna Ranger Station, on Picea, McCune $35569 a$.

Cheiromycina petri D. Hawksw. \& Poelt - Katmai: ca. $600 \mathrm{~m}$ north of Mirror Lake camp, Tфnsberg 42848.

Chrysothrix candelaris (L.) J. R. Laundon - Lake Clark: Camel's Hump on shore of Lake Clark, in rock cavity at inner edge of lakeshore beach, Tønsberg s.n.; shore of Lake Clark, stop 2, W of Hatchet Point, on base of dead trunk of Populus balsamifera, Tonsberg 44127; Chinitna Ranger Station, on slightly overhanging face of Picea trunk, Tønsberg 44356.

Chrysothrix chlorina (Ach.) J. R. Laundon - Lake Clark: north shore of Tuxedni River, on granite cliff, Dillman KD 2003-1230 (TLC: zeorin, calycin, vulpinic acid); slopes and flats above Turquoise Lake, on rock, sheltered, McCune 35029.

Circinaria caesiocinerea (Nyl. ex Malbr.) A. Nordin, S. Savić \& Tibell - Katmai: Headwaters Creek, SW of Malone Lake, on rock, dark outcrop by creek, McCune 34204. Tuxedni: Chisik Island, on rock, Talbot 900, 307A, 312, 313 (not confirmed).

Circinaria contorta (Hoffm.) A. Nordin, S. Savić \& Tibell - Lake Clark: shore of Lake Clark ca. $30 \mathrm{~km}$ NE of Port Alsworth, W of Hatchet Point, on rock, wetted lakeshore marble, McCune 35335; on cliff face, McCune 35330.

Cladonia acuminata (Ach.) Norrlin - Lake Clark: near campsite at NW end of Turquoise Lake, among moss on vertical soil bank, Tфnsberg 43829.

Cladonia albonigra Brodo \& Ahti - Katmai: Mt. Katmai C-5 quadrangle, $58.63577^{\circ} \mathrm{N}, 155.446^{\circ} \mathrm{W}$, on humus, Walton 13386 (TLC: 4-O-methylcryptochlorophaeic, merochlorophaeic, paludosic, and protocetraric acids); NW shore of Malone Lake, Tønsberg 43023. Other 
specimens had the morphology and melanotic bases of $C$. albonigra but contained fumarprotocetraric and protocetraric acids, sometimes with a UV+ unknown, Rf B'5C3.

Cladonia amaurocraea (Flörke) Schaerer - Very common on soil, humus, humus over rock, forest floor and in alpine tundra.

Cladonia arbuscula (Wallr.) Flotow - Very common on moss, soil, humus, Sphagnum, humus over rock, rarely on bark.

Cladonia asahinae J. W. Thomson - Tuxedni: Chisik Island; 0.5 miles north of Cannery, on Boulder, Talbot 408.

Cladonia bacilliformis (Nyl.) Glück - Katmai: ca. 600 m S of W end of Malone Lake, Tønsberg 42943.

Cladonia bellidiflora (Ach.) Schaerer - Common on soil, humus, rock, and bark; woodlands, rocky areas, and alpine tundra.

Cladonia borealis S. Stenroos - Very common on humus and soil and low elevations to alpine; with usnic, barbatic, and \pm norbarbatic (4- $O$-demethylbarbatic) acids.

Cladonia botrytes (K. Hagen) Willd. - Occasional on wood and humus; not yet recorded from Katmai.

Cladonia cariosa (Ach.) Sprengel - Katmai: NW shore of Malone Lake, Thnsberg 43028 (TLC: atranorin, trace fatty acid).

Cladonia carneola (Fr.) Fr. - Common on soil, humus, dead organic material, bark, and wood.

Cladonia cenotea (Ach.) Schaerer - Occasional on bark, wood, soil, and humus.

Cladonia cervicornis subsp. verticillata (Hoffm.) Ahti - Fairly common on humus.

Cladonia chlorophaea (Flörke ex Sommerf.) Sprengel - Common on soil, moss, forest floor, humus, bark, soil over rock, and wood (TLC of several specimens: fumarprotocetraric and protocetraric acids.

Cladonia coccifera (L.) Willd. - Numerous records in Talbot et al. (1992) and NPS database require TLC for separation from $C$. borealis. The following specimens were confirmed to have usnic acid and zeorin by TLC: Nelson 13-39, 13-98, 13-160, 13-167. Tuxedni: Talbot 981.

Cladonia coniocraea (Flörke) Sprengel - Occasional, on dead wood, humus, and bark; recorded from Katmai and Tuxedni.

Cladonia cornuta subsp. cornuta (L.) Hoffm. - Common on humus, soil, and humus over rock, rarely on bark.

Cladonia cornuta subsp. groenlandica (E. Dahl) Ahti - Katmai: $2 \mathrm{~km} \mathrm{~N}$ of Hammersly Lake, on humus in tundra, Walton 13126 . Lake Clark: $60.5643^{\circ} \mathrm{N}, 154.2137^{\circ} \mathrm{W}, 991 \mathrm{~m}$, alpine tundra, Walton 15910.

Cladonia crispata var. crispata (Ach.) Flotow - Common on soil, humus, forest to alpine tundra.

Cladonia crispata var. cetrariiformis (Delise) Vainio - Katmai: Between Hammersly Lake and American Creek, on humus, Walton 13311; Ridgetop W of Contact Creek, Spickerman 110.

Cladonia cryptochlorophaea Asah. - Katmai: low rocky ridge NE of Mirror Lake, Tønsberg 42819. Lake Clark: shoulder of mountain overlooking Tuxedni Bay, among moss over soil on shaded shelf in cliff, Tфnsberg 44258.

Cladonia cyanipes (Sommerf.) Nyl. - Common on soil, moss, and tree bases, forests to alpine tundra.

Cladonia deformis (L.) Hoffm. - Occasional on soil, humus, bark or wood.

Cladonia digitata (L.) Hoffm. - Katmai: Brooks Lodge, Brooks Falls area, on decaying wood (Schindler 1990; not confirmed).

Cladonia ecmocyna Leighton - Only one record from Katmai, no records from Lake Clark, and five records from Tuxedni (Talbot et al. 1992).

Cladonia fimbriata (L.) Fr. - Common on humus, soil, bark, wood, rotting logs, and soil over rock.

Cladonia furcata (Hudson) Schrader - Katmai: occasional on soil and humus. No records from Lake Clark.

Cladonia gracilis (L.) Willd. - Very common on soil, moss, humus, tundra sod. Four subspecies 
are common: C. gracilis subsp. elongata (Jacq.) Vainio, C. gracilis subsp. gracilis (L.) Willd. and $C$. gracilis subsp. turbinata (Ach.) Ahti, and C. gracilis subsp. vulnerata Ahti.

Cladonia granulans Vainio - So far known from a single site in the area, where it was locally abundant. Katmai: rocky alpine ridge W of Contact Creek, on rock, soil in crevice, and moss over rock, McCune 34058, 34092 (TLC: usnic and squamatic acids); Spickerman 111, 116, 170, Tonsberg 42864, 42867a.

Cladonia grayi G. K. Merr. ex Sandst. Tuxedni: of two specimens reported as this (Talbot et al. 1992), one was confirmed as $C$. grayi (TLC: grayanic acid), while the other was moribund $C$. pleurota (TLC: usnic acid and zeorin).

Cladonia kanewskii Oksner - Occasional on humus, mineral soil, plant detritus, and moss over rock (TLC: usnic acid only).

Cladonia luteoalba Wheldon \& A. Wilson - Katmai: low rocky ridge NE of Mirror Lake, Tфnsberg 42815. Lake Clark: saddle on ridge near headwaters of Johnson River, partial shade, mesic, mineral soil, Walton 19208; shoulder of basin on E side of Saddle Mountain, on moss in scree, alpine, Tфnsberg 44192; trail to Tanalian Falls from Port Alsworth, on organic matter, Rosentreter 18460.

Cladonia macilenta Hoffm. - Occasional on humus and wood; four records from Lake Clark, but not recorded from Katmai.

Cladonia macroceras (Delise) Hav. - Common on humus, often in alpine tundra.

Cladonia macrophylla (Schaerer) Stenh. - Common on humus, organic soil, and moss over rock in forests, woodlands and tundra.

Cladonia macrophyllodes Nyl. - Katmai: Katmai Bay Creek, $57.98987^{\circ} \mathrm{N} 155.03092^{\circ} \mathrm{W}, 24 \mathrm{~m}$, partial shade, mesic, organic soil, Walton 18673 . Lake Clark: $60.60531^{\circ} \mathrm{N} 154.35904^{\circ} \mathrm{W}, 539$ $\mathrm{m}$, on humus, Walton 13719; saddle on ridge near headwaters of Johnson River, full sun, mesic, thin organic material over mineral soil, Walton 19219; slopes and flats above Turquoise Lake, Walton 19221, summit of Slope Mountain, overlooking Tuxedni Channel, partial shade, mesic, mineral soil over rock, Walton 19223.

Cladonia maxima (Asah.) Ahti - We are reluctant to apply this name because of confusion with some forms of $C$. gracilis. We have, however, recorded it from several sites at Lake Clark. Talbot et al. (1992) reported many collections from Tuxedni.

Cladonia mitis Sandst. - Katmai: Common on soil and humus. Not recorded from Lake Clark, but Talbot et al. (1992) reported several records from Tuxedni.

Cladonia nipponica Asah. - Common on humus and soil, forests to tundra, partial shade to full sun.

Cladonia nitens Ahti - Tuxedni: Chisik Island, low herb snowbed, Talbot 813. Originally reported as Cladonia cervicornis subsp. verticillata (Talbot et al. 1992).

Cladonia ochrochlora Flörke - Common on bark, wood, and humus, mainly low elevation forests and woodlands.

Cladonia phyllophora Hoffm. - Common on humus and soil, rocky areas, woodlands, and alpine tundra,

Cladonia pleurota (Flörke) Schaerer - Common on humus, mosses, soil, and humus over rock, open forests to tundra; TLC: usnic and porphyrilic acids, zeorin.

Cladonia pocillum (Ach.) Grognot - Lake Clark: trail to Tanalian Falls from Port Alsworth, partial shade, mesic, organic soil over mineral soil, Walton 19254.

Cladonia pyxidata (L.) Hoffm. Common on humus, bark, and soil.

Cladonia rangiferina (L.) F. H. Wigg. - Very common on humus, soil, rarely on bark or wood, forests to tundra.

Cladonia scabriuscula (Delise) Nyl. - Common on moss, wood, humus, and Sphagnum, in forests and woodlands.

Cladonia $\boldsymbol{c f}$. turgida Hoffm. - Katmai: ridge above Hammersly Lake, alpine tundra, on soil, Nelson 13-38. Thallus K+ yellow and P-, with atranorin only by TLC. Consisting only of very large suberect squamules with a smooth, non-scabrid upper surface, morphologically 
consistent with $C$. turgida. The squamules appear somewhat bleached, suggesting that they may be partly deteriorated. Ahti \& Stenroos (2013) allow for rare occurrence of this species with little or no fumarprotocetraric acid.

Cladonia singularis S. Hammer - Although we did not record this from Katmai or Lake Clark, it occurs at nearby Tuxedni, where it was reported as C. decorticata by Talbot et al. (1992), prior to the description of $C$. singularis as a new species. Four specimens were seen in WIS by McCune: Talbot 88006-35, Talbot 88017-36, 847, 1009. It is also known from the Denali area (Stehn et al. 2015).

Cladonia squamosa Hoffm. - Common on soil, humus, bark, and wood, forests to alpine tundra.

Cladonia stellaris (Opiz) Pouzar \& Vězda - Occasional on soil and humus.

Cladonia stellaris var. aberrans (Abbayes) Ahti - Lake Clark: shoulder of basin on E side of Saddle Mountain, on soil, McCune 35441; shoulder of mountain overlooking Tuxedni Bay, on alpine sod, McCune 35461; Tanalian Falls SE of Port Alsworth, on forest floor, McCune 34899.

Cladonia straminea (Sommerf.) Flörke (Syn.: C. metacorallifera) - Occasional on humus, plant debris, moss, and moss over rock.

Cladonia stricta (Nyl.) Nyl. - Katmai: ca. 1 km SW of Malone Lake, on soil, Nelson 13-273. Lake Clark: fen W of Two Lakes, humic soil, Walton 13913; S end of Pickerel Lakes, humic soil, Walton 13593; slopes and flats above Turquoise Lake, alpine tundra, mineral soil in crevice of rock pile, Walton 19253; SW of Telaquana Lake, partial shade, mesic depression, Walton, 19110.

Cladonia stygia (Fr.) Ruoss - Common on humus and soil.

Cladonia subfurcata (Nyl.) Arnold - Occasional on soil and humus, mainly in Katmai, two records from Lake Clark.

Cladonia subulata (L.) F. H. Wigg. - Occasional on soil and forest floor. Katmai: Brooks Lodge, Brooks Falls area, on forest floor (Schindler 1990); Malone Lake, Nelson 13-256; shoreline on east side of Hammersly Lake, Nelson 13-116.

Cladonia sulphurina (Michaux) Fr. - Common on moss, humus, organic soil, wood, and bark

Cladonia umbricola Tønsberg \& Ahti - Occasional on bark and wood, less often on humus.

Cladonia uncialis (L.) F. H. Wigg. - Very common on humus, forest floor, organic soil, and soil, forests to alpine tundra.

Cladonia verruculosa (Vainio) Ahti - Reported from Tuxedni (Talbot et al. 1992) but not seen by us from Katmai or Lake Clark.

Cliostomum griffithii (Sm.) Coppins - Katmai: shore of Naknek Lake, bay just N of Brooks Camp, below crumbling outcrops, Spickerman 161. Lake Clark: trail to Tanalian Falls from Port Alsworth, on dry twig of Picea glauca, Tonsberg 43728.

Coenogonium pineti (Ach.) Lücking \& Lumbsch - Lake Clark: shore of Lake Clark, stop 2, W of Hatchet Point, on conk on decaying root of Betula near lake, Tonsberg 44141; W side of Turquoise Lake, on shaded, hanging, dead Betula nana branches, Tønsberg 43869.

Collema curtisporum Degel. - Katmai: Coville Lake, on Salix snag, Walton 17083 (Stehn et al. 2015). Lake Clark: near west end of Portage Lake, on Populus balsamifera bark, McCune 35187.

Collema furfuraceum (Arnold) Du Rietz - Common on bark, especially Populus and Salix, also Alnus and Betula.

Collema glebulentum (Nyl. ex Crombie) Degel. - Lake Clark: near campsite at NW end of Turquoise Lake, on rock, gabbro or diorite, lakeshore, McCune 35083a; near outlet of Turquoise Lake, on rocks, semi-aquatic, Rosentreter 18584; shore of Lake Clark ca. $30 \mathrm{~km}$ NE of Port Alsworth, W of Hatchet Point, on cliff face, McCune $35323 b$.

Collema leptaleum Tuck. - Occasional on Populus balsamifera, less often on Picea.

Collema nigrescens (Hudson) DC. - Katmai: Headwaters Creek, SW of Malone Lake, Tønsberg 42998b. Lake Clark: shore of Chinitna Bay, ca. 3 km ENE of Chinitna Ranger Station, on Populus bark, Rosentreter 18926. 
Collema subflaccidum Degel. - Lake Clark: Chinitna Ranger Station, on Populus trunk, McCune 35594a; shore of Chinitna Bay, ca. 3 km ENE of Chinitna Ranger Station, on Populus, McCune 35648a. Also reported from Tuxedni (Talbot et al. (1992).

Cryptothele granuliformis (Nyl.) Henssen - Lake Clark: occasional on soil, moss, and rock; not recorded from Katmai.

Cybebe gracilenta (Ach.) Tibell - Lake Clark: near mouth of Horn Creek E of Chinitna Ranger Station, on Populus balsamifera, Nelson 14-529.

Cyphelium inquinans (Sm.) Trevisan - Lake Clark: near SW end of Pickerel Lake, on wood, McCune 35236.

Cyphelium pinicola Tibell - Katmai: partial shade, mesic, on Picea glauca decorticate twig, Walton 19033. Lake Clark: bay on SW side of Portage Lake, on snag, Nelson 14-285.

Cyphelium tigillare (Ach.) Ach. - Occasional on Picea glauca wood.

Cyrtidula sp. - Katmai: near NW shore of Malone Lake, on bark, Betula, McCune 34210, det. Breuss 2014.

Cystocoleus ebeneus (Dillwyn) Thwaites - Occasional on cliff faces.

Dactylina arctica (Richardson) Nyl. - Fairly common at Lake Clark, uncommon at Katmai; on bryophytes or humus in tundra.

Dactylina ramulosa (Hook.) Tuck. - Fairly common at Lake Clark, uncommon at Katmai; on bryophytes or humus in tundra.

Dactylospora sp. - Katmai: near shore of Naknek Lake, $\mathrm{N}$ of Brooks Camp, Tonsberg 42636c. Lake Clark: Chinitna Ranger Station, on Lobaria anomala on trunk of Picea sitchensis inland from beach, Tфnsberg 44227.

Dactylospora sp. 2 - Katmai: near shore of Naknek Lake, $\mathrm{N}$ of Brooks Camp, on rock, lakeside cliffs, McCune 32812. ITS sequence indicates Dactylospora. Parasitizing a white sterile thallus; spores brown, 1-septate 9-10.5 $\times 4.5-5 \mu \mathrm{m}$.

Dendriscocaulon - Lake Clark: Chinitna Ranger Station, on Populus, McCune 35544b, 35593, 35594b, Tønsberg 44316, 44327; on Alnus, Walton 19189; on Picea twigs, Rosentreter 18915. This material can still not be assigned with confidence to a fungal taxon until more comprehensive studies of DNA sequences have been completed. Presumably it is a cyanobacterial photomorph of a Lobaria or Sticta, but no corresponding green algal photomorph was seen.

Dermatocarpon intestiniforme (Körber) Hasse - Katmai: Katmai Bay Cliff, $57.99510^{\circ} \mathrm{N}$ $155.02797^{\circ} \mathrm{W}, 15 \mathrm{~m}$, partial shade, mesic, sedimentary rock near beach, Walton 18565; shoreline of Naknek Lake on peninsula NE of Brooks Camp, on lakeside cliff, McCune 32816. Lake Clark: shore of Lake Clark ca. $30 \mathrm{~km} \mathrm{NE}$ of Port Alsworth, W of Hatchet Point, on wetted lakeshore marble, McCune 35341.

Dermatocarpon luridum (With.) J. R. Laundon - Katmai: Naknek Lake on peninsula NE of Brooks Camp, on lakeshore rock, McCune 32801, 32827; Tanalian Falls SE of Port Alsworth, on rock, Rosentreter 18452.

Dermatocarpon miniatum (L.) W. Mann - Lake Clark: shore of Lake Clark ca. $30 \mathrm{~km}$ NE of Port Alsworth, W of Hatchet Point, on rock, wetted lakeshore marble, cliff face, and lakeshore boulder, McCune 35340, 35334, Walton 19363.

Dermatocarpon reticulatum H. Magn. - Tuxedni: Chisik Island (including Dermatocarpon miniatum, Talbot 700, in Talbot et al. (2012), identified as D. miniatum var. papillosum in WIS).

Dermatocarpon rivulorum (Arnold) Dalla Torre \& Sarnth. - Katmai: low rocky ridge NE of Mirror Lake, on rock, stones in spring, McCune 32978, Tфnsberg 42829; west slope not far below ridge above Hammersly Lake, on rock, Walton 18779. Lake Clark: Lake Clark D-3 quadrangle, $60.8125^{\circ} \mathrm{N}, 154.0080^{\circ} \mathrm{W}, 975 \mathrm{~m}$, on periodically inundated rock in full sun, Walton 13732.

Dermatocarpon sp. - Lake Clark: near outlet of Turquoise Lake, on lakeshore boulder, McCune 35102. Originally identified as $D$. luridum, but the ITS sequence shows it belongs to the $D$. 
taminium/meiophyllizum clade.

Dibaeis baeomyces (L. f.) Rambold \& Hertel - Lake Clark: near campsite at NW end of Turquoise Lake, on soil, McCune 35048; west side of Turquoise Lake, on soil, Tønsberg 43880.

Dimelaena oreina (Ach.) Norman - Lake Clark: near outlet of Turquoise Lake, on lakeshore boulder, McCune 35093; slopes and flats above Turquoise Lake, on $\mathrm{N}$-facing wall of large boulder, Tфnsberg 43747.

Diploschistes gypsaceus (Ach.) Zahlbr. - Katmai: Naknek Lake on peninsula NE of Brooks Camp, on lakeshore rock, Muggia 004 (det. McCune).

Diploschistes muscorum (Scop.) R. Sant. - Lake Clark: bay on SW side of Portage Lake, on soil, Rosentreter 18594.

Diploschistes scruposus (Schreber) Norman - Lake Clark: shore of Lake Clark, stop 2, W of Hatchet Point, on rock, lakeshore outcrops, McCune 35352; Tanalian Falls, SE of Port Alsworth, on rock, Rosentreter 18486, Tønsberg 43664.

Diplotomma (see Buellia)

Eiglera flavida (Hepp) Hafellner - Lake Clark: summit of Slope Mountain, overlooking Tuxedni Channel, on rock, McCune 35377.

Enchylium bachmanianum var. millegranum (Degel.) M. Schultz \& McCune - Katmai: shoreline of Naknek Lake on peninsula NE of Brooks Camp, on mossy rock, McCune 32805, 32806a.

Enchylium polycarpon (Hoffm.) Otalora, P. M. Jørg. \& Wedin - Lake Clark: shore of Lake Clark ca. $30 \mathrm{~km} \mathrm{NE}$ of Port Alsworth, W of Hatchet Point, on rock, cliff face, McCune 35323a, Rosentreter $18797 b$.

Enchylium tenax (Sw.) Gray group - Lake Clark: 4.2 km SW of Pear Lake, 1019 m, on mineral soil in Dryas dwarf shrub tundra, Walton 15926 (sterile); Camel's Hump on shore of Lake Clark ca. $10 \mathrm{~km}$ NE of Port Alsworth, Rosentreter 18772.

Endocarpon adsurgens Vainio - Lake Clark: bay on SW side of Portage Lake, on soil over rock, McCune 35156.

Endocarpon pusillum Hedwig - Lake Clark: shore of Lake Clark ca. $30 \mathrm{~km}$ NE of Port Alsworth, $\mathrm{W}$ of Hatchet Point, on soil over rock, cliff face, McCune 3532la.

Endococcus sp. - Katmai: Shoreline near camp on E side of Hammersly Lake, on Aspicilia on rock, HCl-, McCune 32966. Lake Clark: summit of Slope Mountain, overlooking Tuxedni Channel, on Porpidia tuberculosa on rock, McCune 35403b.

Endococcus macrosporus (Arnold) Nyl. - Katmai: low rocky ridge NE of Mirror Lake, Muggia 159, uncertain ID.

Endococcus propinquus (Körber) D. Hawksw. - Katmai: gentle slopes approaching low rocky ridge NE of Mirror Lake, on Porpidia flavocaerulescens, Muggia 140.

Enterographa zonata (Körber) Källsten ex Torrente \& Egea - Lake Clark: bay on SW side of Portage Lake, on rock wall, Tønsberg 43912.

Ephebe hispidula (Ach.) Horwood - Lake Clark: Camel's Hump on shore of Lake Clark ca. $10 \mathrm{~km}$ NE of Port Alsworth, partial shade, mesic, boulder side, Walton 19361.

Ephebe lanata (L.) Vainio - Katmai: north of Mirror Lake camp, Tonsberg 42841b, Nelson 13237. Lake Clark: shoulder of mountain overlooking Tuxedni Bay, in depression on rock, McCune 35497.

Ephebe perspinulosa Nyl. - Katmai: ca. $200 \mathrm{~m} \mathrm{~N}$ of Mirror Lake camp, on rock, streamside noncalcareous boulder, McCune 34026. Lake Clark: slopes and flats above Turquoise Lake, in depressions on rock, McCune 35032; shoulder of mountain overlooking Tuxedni Bay, on rock, Rosentreter 18854.

Epilichen scabrosus (Ach.) Clem. - Katmai: alpine ridge above Hammersly Lake, on soil, Nelson 13-139. Lake Clark: Camel's Hump on shore of Lake Clark ca. $10 \mathrm{~km}$ NE of Port Alsworth, Rosentreter 18679; slopes and flats above Turquoise Lake, on Baeomyces on soil, McCune 34964.

Erioderma pedicellatum (Hue) P. M. Jørg. - Occasional but very sparse and small populations, usually on Picea twigs, rarely on Betula (Miller \& Walton 2013, Stehn et al. 2015). 
Euopsis granatina (Sommerf.) Nyl. - Common on rock or lichens or mosses over rock, rarely on soil.

Euopsis pulvinata (Schaerer) Nyl. - Occasional on rock or pebbles, less often on soil or the microliverwort Anthelia over soil.

Evernia mesomorpha Nyl. - Katmai: Occasional but sparse on Picea. Not recorded from Lake Clark or Tuxedni.

Flavoplaca citrina (Hoffmann) Arup, Frödén \& Søchting - Katmai: shoreline of Naknek Lake on peninsula NE of Brooks Camp, on rock, McCune 32784, 32808, Tønsberg 42723a, 42700. This is the first genetically verified collection of this species from North America. Most other checked collections belong to F. austrocitrina. Lake Clark: shore of Lake Clark ca. $30 \mathrm{~km} \mathrm{NE}$ of Port Alsworth, W of Hatchet Point, on thin soil over outcrops, McCune 35331, 35332.

Frutidella caesioatra (Schaerer) Kalb - Occasional on bryophytes on streamside rock, on liverwort in rock crevice, moss over rock, and organic matter. Katmai: Fryday \& Tønsberg (2015).

Frutidella pullata (Norman) Schmull - Katmai: Alluvial flats near camp on E side of Hammersly Lake, Tфnsberg 42789, 42803, 42805, 42806. Lake Clark: shoulder of mountain overlooking Tuxedni Bay, on Alnus viridis in a dense Alnus thicket, Tфnsberg 44265; slopes and flats above Turquoise Lake, on moss over humus on rain-exposed rock, Tфnsberg 43789a.

Fulgidea oligospora (Timdal) Bendiksby \& Timdal - Lake Clark: Tanalian Falls SE of Port Alsworth, on wood, vertical face of burned stump, Tønsberg 43698 (with Hypocenomyce scalaris).

Fuscidea aleutica (Degel.) Fryday - Katmai: low rocky ridge NE of Mirror Lake, on rock, McCune 34006.

Fuscidea intercincta (Nyl.) Poelt - Katmai: N end of ridge $\mathrm{W}$ of Contact Creek, on rock, McCune 34088, 34099; shoreline near camp on north side of Mirror Lake, on boulder on beach, McCune 34020; low rocky ridge NE of Mirror Lake, Muggia 144 (det. McCune). New to Alaska; previously known from B.C., northern Europe and Scandinavia.

Fuscidea mollis (Wahlenb.) V. Wirth \& Vězda - Katmai: low rocky ridge NE of Mirror Lake, on rock, McCune 32989, 34007.

Fuscidea pusilla Tønsberg - Occasional on Alnus, Betula, Picea, and Salix. The species is morphologically and chemically similar to F. lightfootii (Sm.) Coppins \& P. James, which is not known from North America; needs sequencing for conclusive identification; see Zahradníková et al. 2018).

Fuscopannaria ahlneri (P. M. Jørg.) P. M. Jørg. - Common on Alnus and Picea bark, lowelevation, forests. Tфnsberg 42617 from Katmai and 44315 (with Rinodina sp.) from Lake Clark are fertile.

Fuscopannaria alaskana P. M. Jørg. \& Tønsberg - Lake Clark: near campsite at NW end of Turquoise Lake, on rock, lakeshore, McCune 35083b; on branch of dead Salix, Tonsberg 43834.

Fuscopannaria confusa (P. M. Jørg.) P. M. Jørg. - Common on Betula, Picea, Populus, and Salix, less often on rock or lichens over rock.

Fuscopannaria leucostictoides (Ohlsson) P. M. Jørg. - Lake Clark: shore of Chinitna Bay, ca. 3 km ENE of Chinitna Ranger Station, on bark, Populus, Rosentreter 18934; trail to Tanalian Falls from Port Alsworth, on bark, Rosentreter 18504.

Fuscopannaria mediterranea (Tav.) P. M. Jørg. - Katmai: occasional on Populus and Salix, low elevation forests and woodlands near Brooks Camp; not recorded from Lake Clark.

Fuscopannaria praetermissa (Nyl.) P. M. Jørg. - Occasional on soil, soil over rock, moss and detritus on lakeshore rock, crevices in cliff.

Fuscopannaria ramulina P. M. Jørg. \& Tønsberg - Katmai: near Brooks Camp, S of Brooks River, along road and trail toward viewing platform, Tønsberg 42620 (det. Jørgensen 2014). Lake Clark: near west end of Portage Lake, on Populus balsamifera, McCune 35180. Also occurring in Denali and Klondike Gold Rush Parks (Spribille et al. 2010, Stehn et al. 2015).

Fuscopannaria viridescens P. M. Jørg. \& Zhurb. - Katmai: Alluvial flats near camp on E side of 
Hammersly Lake, on organic matter, McCune 32957. Lake Clark: bay on SW side of Portage Lake, partial shade, mesic, soil over rock, Walton 19187, Tønsberg 43941; Turquoise Lake, on lakeshore boulder, McCune 35091; frost boil, McCune 35023, Rosentreter 18545; summit of Slope Mountain, overlooking Tuxedni Channel, on soil over rock, McCune 35369. These are apparently the southernmost records for the species, based on discussion by Stehn et al. (2015).

Graphis scripta (L.) Ach. - Lake Clark: shore of Lake Clark ca. 30 km NE of Port Alsworth, W of Hatchet Point, on Alnus viridis just inland from lakeshore beach, Tønsberg 44100.

Gyalecta kukriensis (Räsänen) Räsänen - Katmai: shoreline of Naknek Lake on peninsula NE of Brooks Camp, on rock, Muggia 020.

Gyalideopsis piceicola (Nyl.) Vězda - Lake Clark: Chinitna Ranger Station, on twigs of Picea sitchensis inland from beach, Tønsberg 44325; on Alnus viridis inland from beach meadow, Tфnsberg 44300, 44341.

Gyalolechia flavovirescens (Wulfen) Søchting, Frödén \& Arup - Katmai: shoreline of Naknek Lake on peninsula NE of Brooks Camp, on lakeside cliff, McCune 32813. Lake Clark: bay on SW side of Portage Lake, on rock, McCune 35169c; shore of Lake Clark ca. $30 \mathrm{~km}$ NE of Port Alsworth, W of Hatchet Point, on cliff face, McCune 35325; Lake Clark: Tanalian Falls SE of Port Alsworth, on rock, McCune 34895.

Gyalolechia xanthostigmoidea (Räsänen) Søchting, Frödén \& Arup s. l. - Occasional on bark (Picea, Populus), less often on rock. This morphospecies is polyphyletic and it is not clear whether the clade represented by our material accords with the type.

Gyrographa gyrocarpa (Flotow) Ertz \& Tehler - Lake Clark: Camel's Hump on shore of Lake Clark ca. $10 \mathrm{~km}$ NE of Port Alsworth, on rock in cavity, lakeshore beach, Tønsberg 44084 (TLC: schizopeltic acid (major) with traces of 4-5 unidentified substances; gyrophoric acid not detected); Tønsberg 44085b (TLC: schizopeltic acid (major), gyrophoric acid (trace)).

Helocarpon crassipes Th. Fr. - Tuxedni: Chisik Island, Cassiope stelleriana heath, Talbot 8801024 (Talbot et al. 1992).

Heterodermia galactophylla (Tuck.) Culb. - Occasional at low elevations, especially on Populus bark, but also on conifers.

Heterodermia japonica (Sato) Swinscow \& Krog - Katmai: shore of Naknek Lake, bay just N of Brooks Camp, below crumbling outcrops, on Populus balsamifera, Nelson 13-174.

Heterodermia speciosa (Wulfen) Trevisan - Lake Clark: occasional on Populus balsamifera. Not recorded from Katmai.

Hydropunctaria rheitrophila (Zschacke) Keller, Gueidan \& Thüs - Katmai: ridge above Hammersly Lake, on granite in alpine streamlet, McCune 32949a.

Hydropunctaria scabra (Vězda) C. Keller, Gueidan \& Thüs - Katmai: Camp at west end of Malone Lake, on rock, noncalcareous, beach cobbles, McCune 34234, 34236; low rocky ridge NE of Mirror Lake, on stones in spring, McCune 32979a.

Hymenelia heteromorpha (Kremp.) Lutzoni - Lake Clark: shore of Lake Clark, stop 2, W of Hatchet Point, on rock, wetted lakeshore, McCune 35361.

Hypocenomyce scalaris (Ach.) M. Choisy - Lake Clark: trail to Tanalian Falls from Port Alsworth, on log, dead conifer, McCune 34936; on burned wood, Tфnsberg 43654.

Hypogymnia apinnata Goward \& McCune - Common in low elevation forests and woodlands, mostly on conifer bark and wood, also on Betula.

Hypogymnia austerodes (Nyl.) Räsänen - Occasional, mainly on conifers, less often on Betula or mossy rock. Some of the specimens represent the papillate/isidiate morph where the cortex on the propagules is slow to break down and form soredia.

Hypogymnia bitteri (Lynge) Ahti - Very common, mainly on conifer bark and wood; also on Betula, Salix, and rock.

Hypogymnia hultenii (Degel.) Krog - Fairly common in low elevation forests and woodlands, on conifer and hardwood bark and wood.

Hypogymnia lophyrea (Ach.) Krog - Occasional in low-elevation near-coastal forests and 
woodlands, on both hardwoods and conifers.

Hypogymnia occidentalis L. Pike - Common in low elevation woodlands and forests, mainly on conifer bark and wood; also on Betula.

Hypogymnia physodes (L.) Nyl. - Common on bark and wood of both conifers and hardwoods.

Hypogymnia pulverata (Nyl. ex Crombie) Elix - Occasional on bark and wood, mainly on conifers, also on hardwoods. All specimens tested belonged to the P+ chemotype. See distribution and notes in Nelson et al. 2011, Stehn et al. 2015).

Hypogymnia subobscura (Vainio) Poelt - Lake Clark: fairly common on humus, humus over rock, rock, gravelly soil, and tundra sod. Although we have seen 22 specimens from Lake Clark, we have not recorded it from Katmai, a curious biogeographic pattern considering the circumpolar distribution of this species.

Hypogymnia tubulosa (Schaerer) Hav. - Katmai: $58.0048^{\circ} \mathrm{N}, 155.0443^{\circ} \mathrm{W}, 18 \mathrm{~m}$, on Betula neoalaskana branch, Walton 18610. Lake Clark: Chinitna Ranger Station, partial shade, mesic, Picea branch, Walton 19201.

Hypogymnia vittata (Ach.) Parrique - Not seen from Katmai or Lake Clark, but likely to be found in the more coastal areas of those parks. The reports from Tuxedni (Talbot et al. 1992) were based on misidentifications of $H$. apinnata, $H$. occidentalis, and $H$. physodes (specimens seen in WIS).

Hypogymnia wilfiana Goward, T. Sprib. \& Ahti - Lake Clark: on Picea glauca branch, Walton 13551.

Icmadophila ericetorum (L.) Zahlbr. - Lake Clark: Chinitna Ranger Station, partial shade, decayed Picea stump, Walton 19163; SW end of Pickerel Lake, on organic matter, Rosentreter 18641; trail to Tanalian Falls from Port Alsworth, on organic matter, Rosentreter 18472.

Illosporium carneum Fr. - Katmai: on Peltigera sp., Walton 17057.

Immersaria athroocarpa (Ach.) Rambold \& Pietschm. - Katmai: ridge above Hammersly Lake, alpine, Muggia 060. Lake Clark: shore of Lake Clark, stop 2, W of Hatchet Point, on rock, lakeshore outcrops, McCune 35354.

Imshaugia aleurites (Ach.) S. F. Meyer - Common on bark and wood, mainly Picea, also Betula and Salix.

Ionaspis sp. cf. alba Lutzoni - Lake Clark: bay on SW side of Portage Lake, on rock, wetted lakeshore boulder, McCune 35138. This specimen is similar in some ways to Ionaspis alba, including the small spores, nonreactive apothecial section, but differs in habitat and pigmentation. Furthermore, the sequence bears little resemblance to that of alba from GenBank (Fig. 3).

Ionaspis lacustris (With.) Lutzoni s.1. - Katmai: ca. 1 km SW of Malone Lake, Tфnsberg 42991; shoreline near camp on E side of Hammersly Lake, on rock, shoreline cobbles, McCune 32968. Lake Clark: near campsite at NW end of Turquoise Lake, on rock, iron-stained lakeshore, McCune 35068; shoulder of basin on E side of Saddle Mountain, on soil and rock, damp shale cliffs, McCune 35431, 35440; south end of Pickerel Lake, on stones, McCune $35261 \mathrm{~b}$. Characterized by it brownish epihymenial granules and relatively large spores, we found considerable morphological and genetic variation and suspect that multiple species are involved (Fig. 3). For example, McCune 35431 has cream-white disks with a brown rim and a continuous cream to tan thallus. McCune 32968 has a rusty thallus, reddish brown to brown disk, and epihymenium that is brown pigmented but lacking granules.

Ionaspis sp. cf. lavata H. Magn. - Lake Clark: shoulder of mountain overlooking Tuxedni Bay, on rock in ephemeral snowmelt stream, McCune 35500. This collection was distinctive among our Ionaspis in having a chinky-areolate rather than continuous thallus. Furthermore the upper hymenium was $\mathrm{K}+$ magenta (rather than violet) and the thallus was gray. The pigmentation and hymenial reaction thus differ from the pinkish to white, continuous to rimose thallus and $\mathrm{K}$ - epihymenium of typical I. lavata. The specimen falls in a clade with $I$. odora and I. ventosa (Fig. 3), but sequence similarities were low.

Ionaspis odora (Ach.) Th. Fr. ex Stein - Katmai: ca. $200 \mathrm{~m} \mathrm{~N}$ of Mirror Lake camp, on rock in 
stream, McCune 34036; $300 \mathrm{~km} \mathrm{~S}$ of $\mathrm{W}$ end of Malone Lake, on pebble, Muggia 122 (det. McCune). We have observed tremendous color variation in these specimens with a $\mathrm{K}+$ violet upper hymenium. One specimen from Katmai and two from Kenai Fjords National Park are included in Fig. 3. McCune 34036 had a dark brown thallus similar to many Verrucaria, along with a dark brown disk, while 37009 had a gray thallus and brown disk, and 36259 had a cream to beige thallus and orange-brown disks. Our ITS sequences showed, however, that these color variations are all closely related.

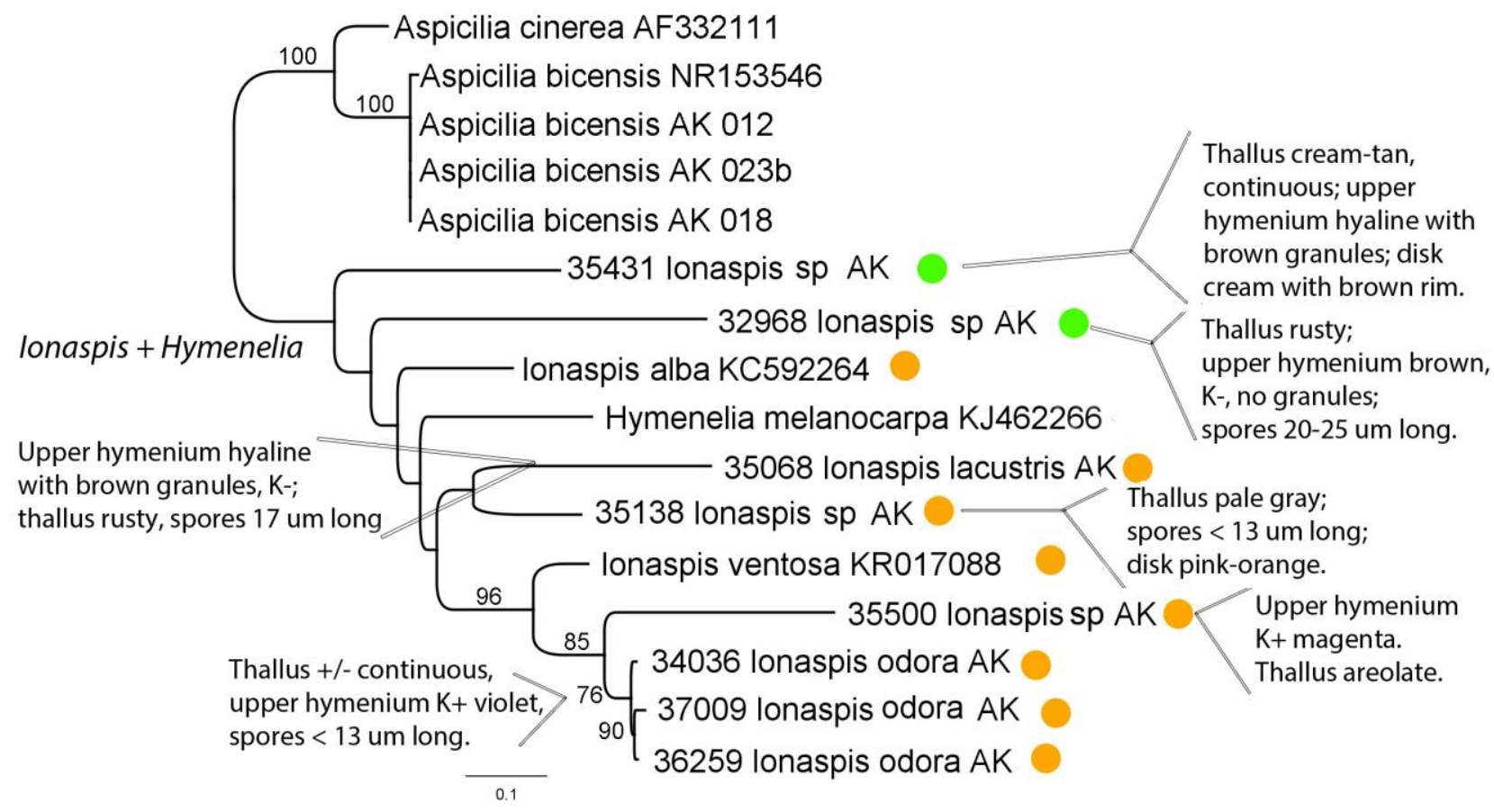

Figure 3 - Maximum likelihood (PhyML) reconstruction of phylogeny of Ionaspis and Hymenelia based on new ITS sequences from southwestern Alaskan parks (McCune collection numbers with "AK") and three sequences from GenBank. The tree was rooted with Aspicilia bicensis and A. cinerea. Sequences in Ionaspis and Hymenelia were very heterogeneous with many indels; much more sampling is needed to capture the biodiversity in this group. Yellow-orange dots indicate Trentepohlia as a photobiont, green dots indicate chlorococcoid algae. New GenBank Accessions for Alaskan specimens: MH579759, MH579760, MH579761, MH579762, MH579763, MH579764, MH579765, MH579766.

Jamesiella anastomosans (P. James \& Vězda) Lücking, Sérus. \& Vězda - Lake Clark: Chinitna Ranger Station, on Picea twig, McCune 35580.

Japewia subaurifera Muhr \& Tønsberg - Common on bark on Alnus, Betula, Picea, and Salix.

Japewia tornoensis (Nyl.) Tønsberg - Common at low elevations on bark on Alnus, Betula, Picea, and Salix; also on conifer wood.

Koerberiella wimmeriana (Körber) Stein - Katmai: shoreline of Naknek Lake on peninsula NE of Brooks Camp, on rock, Muggia 041 (det. McCune); N end of ridge W of Contact Creek, on rock, McCune 34097 (sterile); east side of Hammersly Lake, on shoreline cobbles, McCune 32965. Lake Clark: shoulder of basin on E side of Saddle Mountain, on soil and rock, damp shale cliffs, McCune 35439.

Lambiella furvella (Nyl. ex Mudd) M. Westberg \& Resl - Katmai: ca. 600 m north of Mirror Lake camp, Muggia 194, 197, 200, 203, 204.

Lambiella fuscosora (Muhr \& Tønsberg) M. Westb. \&. Resl - Lake Clark: $250 \mathrm{~m}$ NE of Chinitna Bay Ranger Station, near site of prehistorical pit houses, on bark, Betula, McCune 35667a.

Lambiella sp. - Katmai: shoreline on east side of Hammersly Lake, McCune 32969.

Lasallia pensylvanica (Hoffm.) Llano - Katmai: near Cucumber Lake, on rock outcrop, Walton 
13050. Lake Clark: partial shade, mesic, rock outcrop, Walton 13600.

Lathagrium fuscovirens (With.) Otalora, P. M. Jørg. \& Wedin - Katmai: shoreline of Naknek Lake on peninsula NE of Brooks Camp, on beach cliff, Nelson 13-11. Lake Clark: shore of Lake Clark ca. $30 \mathrm{~km}$ NE of Port Alsworth, W of Hatchet Point, on wetted lakeshore marble, McCune 35339; on cliff face, McCune 35322a, on $\mathrm{HCl}+$ rock, McCune 35307c.

Lathagrium undulatum var. granulosum (Degel.) M. Schultz \& McCune - Tuxedni: Chisik Island, low elevation Populus forest, on Populus trichocarpa, Talbot 87040-26 (not confirmed).

Lecania naegelii (Hepp) Diederich \& van den Boom - Katmai: shore of Naknek Lake, bay just N of Brooks Camp, below crumbling outcrops, on twig, Spickerman 222. The pigmentation of the apothecial section is like Bacidia circumspecta or Lecania naegelii, but the spores are too broad for the former and there is no hint of a paler apothecial margin as in the latter. The apothecia are near black, the spores are 1-3-septate, $17.4-22.6 \times 4.1-5.3 \mu \mathrm{m}$, and there is hardly a visible thallus.

Lecanora albellula Nyl. - Tuxedni: Chisik Island, on wood, Talbot 1239, Talbot 1240 (both specimens listed as L. piniperda in Talbot et al. 1992).

Lecanora allophana Nyl. - Occasional on bark, especially Populus. Our material includes var. sorediata from both Katmai (Tфnsberg 42750a, b) and Lake Clark (Tønsberg 44113b). Lecanora allophana including var. sorediata differs so much from European material that it is difficult to accept them as conspecific.

Lecanora anopta Nyl. - Katmai: ca. $600 \mathrm{~m}$ S of W end of Malone Lake, on wood, Picea branches, McCune 34149a. Lake Clark: near SW end of Pickerel Lake, on wood, Picea stump, McCune $35207,35208$.

Lecanora argentea Oksner \& Volkova - Katmai: shoreline of Naknek Lake on peninsula NE of Brooks Camp, Muggia 014 (det. McCune).

Lecanora argopholis (Ach.) Ach. - Katmai: $300 \mathrm{~m} \mathrm{~S}$ of W end of Malone Lake, on rock, Muggia 126; $600 \mathrm{~m}$ N of Mirror Lake camp, on rock, Muggia 203.

Lecanora bicincta Ramond - Katmai: alpine ridge above Hammersly Lake, Muggia 055, 057, 058, 063, 066; low rocky ridge NE of Mirror Lake, Muggia 146, 156.

Lecanora boligera (Norman ex Th. Fr.) Hedl. - Occasional on Alnus, Betula, Salix; TLC: lobaric acid; all Tønsberg specimens except 43805 det. Arup 2016.

Lecanora caesiosora Poelt — Lake Clark: bay on SW side of Portage Lake, on overhanging rock wall, Tonsberg 43907.

Lecanora cateilea (Ach.) A. Massal. - Lake Clark: Chinitna Ranger Station, on Alnus viridis inland from beach meadow, Tonsberg 44295 (det. Arup 2016).

Lecanora cavicola Creveld - Lake Clark: slopes and flats above Turquoise Lake, on rock below shaded overhang, N-facing part of boulder, Tфnsberg 43762 (TLC: alectorialic acid + satellites).

Lecanora circumborealis Brodo \& Vitik. - Common on bark of Alnus, Betula, Picea, and Populus.

Lecanora contractula Nyl. - Katmai: ridgetop W of Contact Creek, on bryophytes on rock, Spickerman 238 (uncertain ID).

Lecanora epanora (Ach.) Ach. - Tuxedni: Chisik Island; 0.5 miles north of Cannery, on rock, Talbot 310. This specimen was reported as new to Alaska by Talbot et al. (1992).

Lecanora epibryon (Ach.) Ach. - Lake Clark: shore of Lake Clark ca. $30 \mathrm{~km} \mathrm{NE}$ of Port Alsworth, W of Hatchet Point, on soil, Rosentreter 18809; bay on SW side of Portage Lake, over moss on shelf in rock overhang on lakeshore, Tфnsberg 43943 (det. Arup 2016).

Lecanora expallens Ach. - Occasional on bark and wood at low elevations.

Lecanora fuscescens (Sommerf.) Nyl. - Lake Clark: bay on SW side of Portage Lake, on twig, decorticate Picea, McCune 35123, 35124.

Lecanora hybocarpa (Tuck.) Brodo - Lake Clark: Chinitna Ranger Station, on Alnus, McCune 35559; shoulder of basin on E side of Saddle Mountain, on Alnus bark, edge of tundra, McCune 35444; Tanalian Falls SE of Port Alsworth, on Salix bark, McCune 34921. Also 
reported from Tuxedni (Talbot et al. 1992).

Lecanora hypoptoides (Nyl.) Nyl. - Lake Clark: Chinitna Ranger Station, on wood, beach log, McCune 35671.

Lecanora intricata (Ach.) Ach. - Katmai: ca. $200 \mathrm{~m} \mathrm{~N}$ of Mirror Lake camp, on boulder, McCune 34053; midslope below ridge above Hammersly Lake, on rock, Spickerman 56a; shoreline of Naknek Lake on peninsula NE of Brooks Camp, Muggia 013.

Lecanora laatokkaensis (Räsänen) Poelt - Lake Clark: Camel's Hump on shore of Lake Clark ca. $10 \mathrm{~km}$ NE of Port Alsworth, on lakeshore boulder, McCune 35302 (TLC: usnic acid, zeorin, unknown Rf B5 C3).

Lecanora leptacina Sommerf. - Katmai: north of Mirror Lake camp, Tønsberg 42836, 42857 (as L. aff. leptacina, Fryday \& Tønsberg 2015), Nelson 13-78; ridgetop W of Contact Creek, Tфnsberg 42865, 42877.

Lecanora leucococca Sommerf. s.l. - Lake Clark: SW end of Pickerel Lake, on beach rocks, amphibious, McCune 35211 (det. Arup 2016). In the broad sense the species is new to North America. This species is similar to L. polytropa, but differs in the paler, white to grayish white thallus, in the usually flatter apothecia and in usually growing in places near water.

Lecanora marginata (Schaerer) Hertel \& Rambold. - Katmai: alpine ridge above Hammersly Lake, on rock, Muggia 063 (det. McCune).

Lecanora muralis (Schreber) Rabenh. (Protoparmeliopsis muralis) - Katmai: shoreline of Naknek Lake on peninsula NE of Brooks Camp, on rock, noncalcareous, McCune 32775, Muggia 019, Tфnsberg 42719 (usnic acid, zeorin, 3 unidentified terpenoids in moderate to trace amounts). Lake Clark: Camel's Hump on shore of Lake Clark ca. $10 \mathrm{~km}$ NE of Port Alsworth, on slightly overhanging lakeshore rock, Tonsberg 44095; shore of Lake Clark, stop 2, W of Hatchet Point, on rock, lakeshore outcrops, McCune 35350 (TLC: usnic acid, leucotylin, zeorin, unk. terpenoid Rf A5).

Lecanora orae-frigidae R. Sant. - Katmai: Katmai Bay Bear Cam, $58.004836^{\circ} \mathrm{N}-155.044263^{\circ} \mathrm{W}$, 18 m, on driftwood, Walton 18658, 18623. Lake Clark: shore of Chinitna Bay, ca. 4 km ENE of Chinitna Ranger Station, on driftwood, Tønsberg 44374.

Lecanora pacifica Tuck. - Tuxedni: Chisik Island, on Alnus crispa, Talbot 87001-32 (not confirmed by us).

Lecanora polytropa (Hoffm.) Rabenh. - Common on rock. Tuxedni: Chisik Island, on wood, Talbot 1255 (as Lecanora pallida in Talbot et al. 1992).

Lecanora pringlei (Tuck.) Lamb - Lake Clark: slopes and flats above Turquoise Lake, on rock beneath overhang, Nelson 14-419 (Tønsberg TLC: psoromic acid), on rock beneath shaded overhang on $\mathrm{N}$-facing part of boulder, Thnsberg 43764 (TLC: psoromic acid (major), alectorialic acid).

Lecanora pulicaris (Pers.) Ach. - Tuxedni: Chisik Island, on Picea sitchensis, Talbot 826, 827 (Talbot et al. 1992, not confirmed by us).

Lecanora reagens Norman - Lake Clark: bay on SW side of Portage Lake, on rock, McCune $35169 d$.

Lecanora rupicola (L.) Zahlbr. - Katmai: alpine ridge above Hammersly Lake, Muggia 054; low rocky ridge NE of Mirror Lake, Muggia 146.

Lecanora salicicola H. Magn. - Lake Clark: shoulder of basin on E side of Saddle Mountain, on Alnus bark, edge of tundra, McCune 35444; shoulder of mountain overlooking Tuxedni Bay, on Alnus viridis in dense thicket, Tonsberg 44263b (det. Arup 2016).

Lecanora saligna (Schrader) Zahlbr. - Lake Clark: Chinitna Ranger Station, on woody shelf fungus on Picea, McCune 35576.

Lecanora sp. 4 of Śliwa \& Wetmore (2000) - Lake Clark: shore of Chinitna Bay, ca. $3 \mathrm{~km}$ ENE of Chinitna Ranger Station, on Alnus bark, McCune 35650b; shore of Chinitna Bay, ca. 4 km ENE of Chinitna Ranger Station, on weathered wood, McCune 35642. As used by Śliwa \& Wetmore (2000) this may be heterogeneous, including L. laxa in part; see additional notes in McCune (2017). 
Lecanora symmicta (Ach.) Ach. - Common on bark and wood, including Alnus, Picea, Populus, Salix, and Sorbus.

Lecanora symmicta group (Ach.) Ach. - Katmai: ca. $600 \mathrm{~m} \mathrm{~S}$ of W end of Malone Lake, on bark, Salix, McCune 34140c (sorediate, fertile, L. symmicta group det. Tønsberg 2015).

Lecanora torrida Vainio - Lake Clark: shore of Lake Clark, W of Hatchet Point, on rock, wetted lakeshore marble, McCune 35336a.

Lecanora varia (Hoffm.) Ach. - Tuxedni: Chisik Island, Tuxedni Bay, Cook Inlet, on Picea sitchensis, Talbot 1372F (Talbot et al. 1992, misidentification of L. symmicta).

Lecanora xylophila Hue - Katmai: Ninagiak Island in the Shelikof Strait (between Katmai and Kodiak Island), on driftwood (Schindler 1990).

Lecidea auriculata Th. Fr. - Katmai: Ridgetop W of Contact Creek, on granite, McCune 34065 (confirmed by ITS sequence; similar to Adelolecia pilati in many ways but the exciple is $\mathrm{K}+$ violet rather than magenta, and is POL-); Muggia 104. Tuxedni: Chisik Island, low herb snowbed, on Boulder, Talbot 783 (not confirmed by us).

Lecidea confluens (Weber) Ach. - Lake Clark: summit of Slope Mountain, overlooking Tuxedni Channel, on argillite, McCune 35419. An ITS sequence showed a close relationship with $L$. lapicida.

Lecidea erythrophaea Flörke ex Sommerf. - Katmai: near shore of Naknek Lake, N of Brooks Camp, on bark, Populus, McCune 32887, 32751; Tønsberg 42663, det. Z. Palice (2014). Tuxedni: Chisik Island, Populus trichocarpa forest, on Populus, Talbot 88052-X-10 (as Lecidea cf. elabens).

Lecidea hypocrita A. Massal. - Tuxedni: Talbot et al. (1992), misidentification of Porpidia thomsonii.

Lecidea lactea Flörke ex Schaerer - Katmai: low rocky ridge NE of Mirror Lake, on rock, McCune 32998, $200 \mathrm{~m} \mathrm{~N}$ of Mirror Lake, Muggia 184. Lake Clark: near campsite at NW end of Turquoise Lake, on loose rock on gravel flats, McCune 35089; summit of Slope Mountain, overlooking Tuxedni Channel, on rock, McCune 35381.

Lecidea lapicida (Ach.) Ach. - Katmai: alpine ridge above Hammersly Lake, on rock, Muggia 043. Lake Clark: shoulder of mountain overlooking Tuxedni Bay, on rock, McCune 35462; slopes and flats above Turquoise Lake, on rock, McCune 34954; summit of Slope Mountain, overlooking Tuxedni Channel, on rock, McCune 35400.

Lecidea leucothallina Arnold - Katmai: ridge above Hammersly Lake, alpine, on rock, Tønsberg 42777a, 42781; midslope below ridge above Hammersly Lake, Muggia 071; shoreline on east side of Hammersly Lake, Muggia 074. Lake Clark: shoulder of mountain overlooking Tuxedni Bay, on vertical rock face, Tønsberg 44256, on metal-rich rock, McCune 35482 var. kujalae (Räsänen) Hertel.

Lecidea lithophila (Ach.) Ach. - Katmai: ridgetop W of Contact Creek, on granite, McCune 34077.

Lecidea plana (J. Lahm) Nyl. - Lake Clark: saddle on ridge near headwaters of Johnson River, on HCl-rock, McCune 35520.

Lecidea praenubila Nyl. - Katmai: alpine ridge above Hammersly Lake, on rock, McCune 32908 (TLC: stictic acid). Lake Clark: shoulder of mountain overlooking Tuxedni Bay, on rock, McCune 35463.

Lecidea protabacina Nyl. - Katmai: alpine ridge above Hammersly Lake, on rock, Muggia 124, 144c "WP144-147", DNA McCune lab: ITS GenBank KY800506 (McCune et al. 2017). TLC: stictic acid. Lake Clark: slopes and flats above Turquoise Lake, on rock, McCune 35001 .

Lecidea roseotincta Coppins \& Tønsberg - Lake Clark: Chinitna Ranger Station, on Alnus viridis inland from beach meadow, Tфnsberg 44340.

Lecidea silacea Ach. - Lake Clark: shoulder of mountain overlooking Tuxedni Bay, on metal-rich rock; McCune 35487.

Lecidea sphaerella Hedl. - Katmai: near shore of Naknek Lake, N of Brooks Camp, on Populus bark; McCune 32754. 
Lecidea cf. swartzioidea Nyl. - Katmai: low rocky ridge NE of Mirror Lake, on rock, Muggia 144a (lecideoid crust with norstictic acid, uncertain ID, det. McCune).

Lecidea tessellata Flörke - Lake Clark: Camel's Hump on shore of Lake Clark ca. $10 \mathrm{~km} \mathrm{NE} \mathrm{of}$ Port Alsworth, on rock, cliff face, McCune 35291; near campsite at NW end of Turquoise Lake, on lakeshore granite, McCune 35076; on iron-stained lakeshore rock, McCune 35071; slopes and flats above Turquoise Lake, McCune 35000 (ITS sequence, lacking mature typical apothecia).

Lecidea aff. turgidula Fr. - Lake Clark: bay on SW side of Portage Lake, on wood of Picea glauca, somewhat protected, Tфnsberg 43900; on hard wood of Picea glauca, Tønsberg $43897 b$.

Lecidea sp. - Lake Clark: slopes and flats above Turquoise Lake, on rock, McCune 35017. Areoles dark brown, glossy; apothecia black, with persistent margin; exciple interior I-; hypothecium hyaline; spores $6.5-7 \times 3.2-3.5 \mu \mathrm{m}$. Lecidea syncarpa is another brown Lecidea with norstictic acid. But this specimen differs from L. syncarpa in its very dark brown thallus, absence of a gray margin on the areoles, and its I- medulla. An ITS sequence shows that that 35017 probably belongs to Lecidea s. str., but did not match well any sequences in GenBank. This appears to be an undescribed species, but more specimens and sequences are needed.

Lecidella asema (Nyl.) Knoph \& Hertel - Katmai: shoreline of Naknek Lake on peninsula NE of Brooks Camp, on rock, Muggia 037 (det. McCune). Lake Clark: shore of Chinitna Bay, ca. 4 km ENE of Chinitna Ranger Station, on sandstone boulder on shoreline, McCune 35641.

Lecidella bullata Körber - Katmai: above Hammersly Lake, alpine ridge, on rock, McCune 32909.

Lecidella carpathica Körber - Katmai: shoreline of Naknek Lake on peninsula NE of Brooks Camp, on rock, McCune 32792, Muggia O16b (det. McCune). Lake Clark: bay on SW side of Portage Lake, on wetted lakeshore boulder, McCune 35141; shoulder of basin on E side of Saddle Mountain, on stones in tundra, McCune 35452.

Lecidella euphorea (Flörke) Hertel - Katmai: Headwaters Creek, SW of Malone Lake, on bark, Populus, McCune 34190.

Lecidella scabra (Taylor) Hertel \& Leuckert - Katmai: shoreline of Naknek Lake on peninsula NE of Brooks Camp, on shaded rock, McCune 32819a (det. Tønsberg, TLC: arthothelin, xanthones including thuringione), 32819c, Muggia 021c (det. McCune, sorediate; a few apothecia present).

Lecidella stigmatea (Ach.) Hertel \& Leuckert - Katmai: shoreline of Naknek Lake on peninsula NE of Brooks Camp, on noncalcareous rock, McCune 32778, Muggia 021a, 032, 033 (det. McCune). Lake Clark: shore of Lake Clark ca. $30 \mathrm{~km} \mathrm{NE}$ of Port Alsworth, W of Hatchet Point, on rock, cliff face, McCune 35327; shore of Lake Clark, W of Hatchet Point, on cliff face, McCune 35328.

Lecidella wulfenii (Hepp) Körber - Katmai: Shoreline near camp on E side of Hammersly Lake, Spickerman 68. Lake Clark: bay on SW side of Portage Lake, on soil over rock, McCune 35149; near outlet of Turquoise Lake, on tundra sod, McCune 35110.

Lecidoma demissum (Rutstr.) Gotth. Schneider \& Hertel - Occasional on soil, soil over rock, and tundra sod (TLC Tфnsberg 43756: 3 fatty acids; 44237: fatty acid).

Leciophysma furfurascens (Nyl.) Gyelnik - Lake Clark: saddle on ridge near headwaters of Johnson River, on tundra sod, McCune 35516a.

Lempholemma cladodes (Tuck.) Zahlbr. - Lake Clark: shore of Lake Clark ca. $30 \mathrm{~km}$ NE of Port Alsworth, W of Hatchet Point, on cliff face, McCune 35329b, 35322c; on wetted lakeshore marble, McCune 35338.

Lempholemma vesiculiferum Henssen - Lake Clark: shore of Lake Clark ca. $30 \mathrm{~km}$ NE of Port Alsworth, W of Hatchet Point, Rosentreter 18798, 18797 .

Lepra dactylina (Ach.) Hafellner - Common on organic soil, alpine sod, mosses, lichens, wood, and plant detritus; low elevations to alpine.

Lepra excludens (Nyl.) Hafellner - Katmai: shore of Naknek Lake, NNE of Brooks Camp, on rock in shallow cavity in lakeshore cliff, Tønsberg 42724a (ALA, BG); see Tønsberg (2018). 
Lepra ophthalmiza (Nyl.) Hafellner - Katmai: near NW shore of Malone Lake, Tønsberg 43017 (TLC: 4-5 fatty acids; no spores, asci well-developed). Lake Clark: bay on SW side of Portage Lake, on base of Betula neoalaskana in rather dry cavity, Tønsberg 43901; Chinitna Ranger Station, on Alnus, Tфnsberg 44335, 44337. There are two chemotypes: one with two major fatty acids, the other with a range of fatty acids in lower concentrations. The species needs more study.

Lepra panyrga (Ach.) Hafellner - Occasional on organic matter or lichens or mosses over rock, low elevations to alpine.

Lepraria elobata Tønsberg - Lake Clark: E side Turquoise Lake, on dead Betula nana branches in pothole, Tønsberg 43870; bay on SW side of Portage Lake, lignicolous on Picea glauca, Tфnsberg 43919; inlet at SW end of Pickeral Lake, over mineral soil, lakeshore bank,

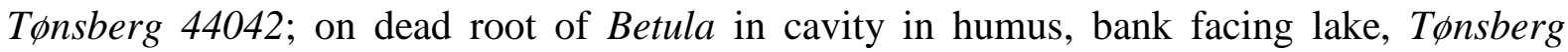
44043. TLC (all specimens): atranorin, stictic acid + satellites, zeorin.

Lepraria eburnea J. R. Laundon - Lake Clark: bay on SW side of Portage Lake, on rock, McCune $35147 a$.

Lepraria finkii (Hue) R. C. Harris - Occasional on moss over bark and sheltered soil or rock. Lake Clark, Tønsberg 43660 \& 43665: atranorin, zeorin, stictic and constictic acids (TLC).

Lepraria incana (L.) Ach. - Lake Clark: North shore of Tuxedni River, on granite cliff, Dillman KD 2003-1214, det. Katie Glew 2003; spot tests: K-, C-, KC-, P-; TLC: zeorin, faint atranorin, fatty acid (Dillman 2003; not confirmed by us).

Lepraria jackii Tønsberg - Katmai: near Brooks Camp, S of Brooks River, along road and trail toward viewing platform, Tфnsberg 42607a.

Lepraria neglecta (Nyl.) Erichsen s.l. - Common on alpine sod, soil, and moss over rock. Katmai: Fryday \& Tønsberg (2015). The material includes the following chemotypes (as in Lendemer 2013) or species, depending on your viewpoint (Table 5).

Table 5 The Lepraria neglecta group in the study area. Other chemotypes present include, for example: atranorin, fumarprotocetraric acid, jackinic/rangiformic acid with satellite, Thnsberg 42860; atranorin, fumarprotocetraric acid, unidentified fatty acid (not jackinic/rangiformic acid),

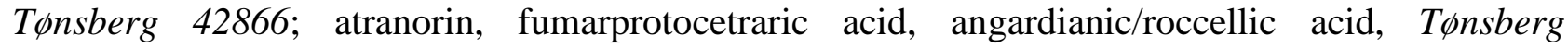
42883; atranorin, psoromic acid, jackinic/rangiformic acid with satellite, Tonsberg 42868, 44174 (pro max. parte); atranorin, psoromic acid, angardianic/roccellic acid, Tфnnsberg 43765.

\begin{tabular}{|c|c|c|}
\hline Taxon & Chemotype & Specimens \\
\hline $\begin{array}{l}\text { Lepraria alpina (B. de Lesd.) Tretiach \& } \\
\text { Baruffo }\end{array}$ & $\begin{array}{l}\text { atranorin, } \\
\text { porphyrilic acid, } \\
\text { fatty acid }\end{array}$ & $\begin{array}{l}\text { Rosentreter 19244; T } \phi \text { nsberg } \\
\text { 43755, } 44189\end{array}$ \\
\hline $\begin{array}{l}\text { Lepraria caesioalba (B. de Lesd.) J. R. } \\
\text { Laundon }\end{array}$ & $\begin{array}{l}\text { fumarprotocetraric } \\
\text { acid, fatty acid }\end{array}$ & $\begin{array}{l}\text { Tonsberg 42882, 43754, } \\
43757,44070\end{array}$ \\
\hline Lepraria neglecta (Nyl.) Erichsen s. str. & $\begin{array}{l} \pm \text { atranorin, } \\
\text { alectorialic acid }+ \\
\text { satellites, fatty acid }\end{array}$ & $\begin{array}{l}\text { Tonsberg 42835, 42878, } \\
44239\end{array}$ \\
\hline $\begin{array}{l}\text { Lepraria cf. svalbardensis Tønsberg } \\
\text { (Tentative; in Svalbard, material with this } \\
\text { chemistry, has been named } L . \\
\text { svalbardensis, but the introduction of } L \text {. } \\
\text { svalbardensis to North America should } \\
\text { be based on material studied by } \\
\text { molecular methods. No material from } \\
\text { Svalbard has so far been sequenced.) }\end{array}$ & $\begin{array}{l}\text { atranorin, stictic acid } \\
+ \text { satellites, fatty } \\
\text { acid }\end{array}$ & $\begin{array}{l}\text { Rosentreter 18822; Tфnsberg } \\
44156,44168,44278,44279\end{array}$ \\
\hline
\end{tabular}


Lepraria rigidula (de Lesd.) Tønsberg - Lake Clark: northern shoreline areas of Chinitna Bay, corticolous on underside of branch of Picea inland from beach meadow, Tфnsberg 44358 (TLC: atranorin, nephrosteranic acid).

Lepraria subalbicans (Lamb) Lamb \& Ward - Lake Clark: shoulder of mountain overlooking Tuxedni Bay, on rock, McCune 35459; slopes and flats above Turquoise Lake, on moss in dry niche in N-facing wall of boulder, Tønsberg 43766 (TLC: thamnolic, angardianic/roccellic acids); on humus over boulder, Tønsberg 43770.

Lepraria torii Pérez-Ortega \& T. Sprib. - Lake Clark: Chinitna Ranger Station, on Picea sitchensis snag with bark at base, Tфnsberg 44285.

Lepraria vouauxii (Hue) R. C. Harris - Katmai: shoreline of Naknek Lake on peninsula NE of Brooks Camp, Tønsberg 42714, 42722. Lake Clark: bay on SW side of Portage Lake, crevice in lakeside cliff, Tønsberg 43932; Camel's Hump on shore of Lake Clark, on moss in crevices in rock wall, Tфnsberg 44066; W of Hatchet Point on shore of Lake Clark, Tønsberg 44122 (TLC: pannaric acid 6-methylester (trace)).

Leptogidium contortum (Henssen) T. Sprib. \& Muggia - Katmai: shore of Naknek Lake, bay just $\mathrm{N}$ of Brooks Camp, below crumbling outcrops, on Salix, McCune 34114b. Lake Clark: Chinitna Ranger Station, on Populus, McCune 35544a.

Leptogium burnetiae C. W. Dodge - Specimens belong to other species, to be determined, but $L$. burnetiae s. str. does not occur in Alaska (Stone \& Lendemer 2016). Specimens previously given this name need to be reassigned: Katmai: Katmai Bay Bear Cam, $58.00484^{\circ} \mathrm{N}-$ $155.04426^{\circ} \mathrm{W}, 18 \mathrm{~m}$, on Populus balsamifera bark, Walton 18523, 18650. Lake Clark: Chinitna Ranger Station, on Picea twig, Walton 19213; shore of Lake Clark, W of Hatchet Point, on boulder, Walton 19248.

Leptogium compactum D. F. Stone, F. Anderson \& J. W. Hinds - Lake Clark: mouth of Horn Creek E of Chinitna Ranger Station, on Alnus, McCune 35604, 35605 (35605 is holotype, NY; both det. D. Stone 2015); Chinitna Ranger Station, on Alnus viridis inland from beach meadow, Tфnsberg 44312; shore of Chinitna Bay, ca. 3 km ENE of Chinitna Ranger Station, on trunks of large Populus balsamifera, Tonsberg 44383 (det. D. Stone 2015).

Leptogium cookii D. F. Stone and Lendemer - Lake Clark: mouth of Horn Creek E of Chinitna Ranger Station, on Alnus, McCune 35603 (holotype, NY; Stone et al. 2016); bay on SW shore of Portage Lake, on lakeshore rock, McCune 35145 (Stone et al. 2016); west end Portage Lake, on Populus, McCune 35188.

Leptogium cyanescens (Rabenh.) Körber - Lake Clark: Chinitna Ranger Station, Rosentreter 18916, Tфnsberg 44313 (perfect medulla and isidia for L. cyanescens, det. Stone 2015); mouth of Horn Creek E of Chinitna Ranger Station, on Populus, McCune 35616; shore of Chinitna Bay, ca. $3 \mathrm{~km}$ ENE of Chinitna Ranger Station, on Populus, McCune 35648b, Tønsberg 44382 ( $L$. cf. cyanescens det. Stone: the isidia are not typical; medulla fits $L$. cyanescens, but was not exactly typical, det. Stone 2015)

Leptogium saturninum (Dickson) Nyl. s.l. - Common as a species group on Alnus, Picea, Populus, and Salix, also on rock; many specimens apparently belong to other species, L. compactum and L. cookii. L. saturninum s. str. does occur in the region (e.g. Katmai, shore of Naknek Lake, on Populus, McCune 32786; S end of Kenai Lake, 141 m, on Populus, McCune 30716, both det. Stone et al. 2016; 60.3053 $\mathrm{N} 154.0017^{\circ} \mathrm{W}, 81 \mathrm{~m}$, closed Picea glauca forest ca. 300 $\mathrm{m}$ from lake, Walton 16641, det. Schultz 2018).

Leptorhaphis epidermidis (Ach.) Th. Fr. - Lake Clark: inlet at SW end of Pickerel Lake, on Betula, McCune 35250.

Lichenomphalia hudsoniana (H. S. Jenn.) Redhead et al. - Lake Clark: partial shade, mesic, on Sphagnum overhanging rock, Walton 16416; 17704.

Lichenomphalia umbellifera (L. : Fr.) Redhead et al. - Lake Clark: by Lake Clark, on heavily decayed wood, Walton 15868; bay on SW side of Portage Lake, on soil, Rosentreter 18592; Camel's Hump on shore of Lake Clark, on soil, Rosentreter 18776; Chinitna Ranger Station, on soil and organic matter, Rosentreter 18894; slopes and flats above Turquoise Lake, on 
soil, Rosentreter 18541.

Lichinella nigritella (Lettau) Moreno \& Egea - Lake Clark: shore of Lake Clark ca. $30 \mathrm{~km}$ NE of Port Alsworth, W of Hatchet Point, on rock, Rosentreter 18791, 18797d.

Lichinodium ahlneri Henssen - Lake Clark: Chinitna Ranger Station, on twigs and trunk of Picea sitchensis inland from beach, Tфnsberg 44324.

Lichinodium sirosiphoideum Nyl. - Katmai: near gravel road between Naknek Lake and Lake Brooks, on Betula, McCune 32894; Nelson 13-285, Tфnsberg 42754, 42763, 42764. Lake Clark: Chinitna Ranger Station, on twig, Picea, McCune 35598; on Betula bark, Tønsberg 44225 (pro parte, in collection with Pseudocyphellaria mallota). Lichinodium canadense Henssen has been reported from the Denali area (Stehn et al. 2015). McCune 32894 and 35598 are genetically identical with European samples; Prieto \& Schultz unpubl.), although they are similar to $L$. canadense in their intermediate lobe size and the clearly corticolous growth. Thus, the morphological and substrate distinctions between $L$. sirosiphoideum and $L$. canadense are not as clear cut as described by Henssen. Some of the specimens cited above may in fact be L. canadense, or the two may be conspecific; more study is needed.

Lobaria anomala (Brodo \& Ahti) T. Sprib. \& McCune - Occasional at low elevations, on Alnus, Picea, and Populus.

Lobaria hallii (Tuck.) Zahlbr. - Common in low elevation moist forests, on various trees and shrubs but most common on Populus and Salix.

Lobaria linita (Ach.) Rabenh. - Common on humus, organic material over mineral soil, and moss.

Lobaria pulmonaria (L.) Hoffm. - Common at low elevations on bark of Picea, Populus, and Salix; also on Alnus, Betula, and rock.

Lobaria retigera (Bory) Trevisan - Katmai: Brooks Lodge, Brooks Falls area, on Salix (Schindler 1990). Lake Clark: Chinitna Ranger Station, on trunk, Populus, McCune 35592, Tønsberg 44317, 44326; near mouth of Horn Creek E of Chinitna Ranger Station, on Populus balsamifera trunk, Walton 19197, 19344.

Lobaria scrobiculata (Scop.) DC. - Common on bark of various species.

Lobothallia alphoplaca (Wahlenb.) Hafellner - Katmai: shoreline of Naknek Lake on peninsula NE of Brooks Camp, Muggia 034 (det. McCune), Tønsberg 42718 (spores globose to ellipsoid; apices of the marginal lobes, albeit appressed, widen at the tips and are not grayish but pale brownish subapically and more strongly pigmented at the tips; TLC: norstictic acid, connorstictic acid). These are members of the Lobothallia alphoplaca/praeradiosa species complex, which is in need of clarification.

Lobothallia melanaspis (Ach.) Hafellner - Lake Clark: near campsite at NW end of Turquoise Lake, on rock, lakeshore, McCune 35054, Tonsberg 43842 (TLC: no substances); shore of Lake Clark, stop 2, W of Hatchet Point, on rock, wetted lakeshore, McCune 35360. An ITS sequence of McCune 35054 showed close relationship to L. melanaspis from Sweden (HQ259272).

Lopadium coralloideum (Nyl.) Lynge - Katmai: alpine ridge above Hammersly Lake, on alpine sod, McCune 32926. Lake Clark: bay on SW side of Portage Lake, over moss on lakeshore cliff, Tønsberg 43940; low ridge above inlet stream to Pickerel Lake, on mosses on humus rich soil, Tønsberg 44062.

Lopadium disciforme (Flotow) Kullhem - Lake Clark: Chinitna Ranger Station, on Picea, McCune

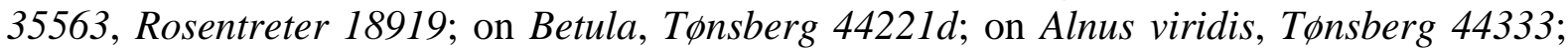
on conks of Porodaedalea pini on trunk of Picea, Tonsberg 44364a.

Lopadium pezizoideum (Ach.) Körber - Lake Clark: occasional on soil, moss over soil, moss over rock, and plant detritus; not recorded from Katmai.

Loxospora elatina (Ach.) A. Massal. - Lake Clark: Chinitna Ranger Station, on trunk of Picea sitchensis inland from beach, Tønsberg 44230.

Loxosporopsis corallifera Brodo, Henssen \& Imshaug - Lake Clark: mouth of Horn Creek E of Chinitna Ranger Station, on Populus balsamifera, McCune 35607.

Massalongia carnosa (Dickson) Körber - Occasional, on moss and soil over rock. 
Megaspora verrucosa (Ach.) Hafellner \& V. Wirth - Lake Clark: summit of Slope Mountain, overlooking Tuxedni Channel, on organic matter, Rosentreter 18832.

Megaspora verrucosa var. mutabilis (Ach.) Nimis \& Cl. Roux - Lake Clark: near west end of Portage Lake, on bark, Populus balsamifera, McCune 35192.

Melanelia agnata (Nyl.) Thell - Katmai: ca. $200 \mathrm{~m} \mathrm{~N}$ of Mirror Lake camp, on rock, Walton $18773 a$; ridgetop $\mathrm{W}$ of Contact Creek, on rock, Walton 18795; slopes and flats above Turquoise Lake, Rosentreter 18562.

Melanelia hepatizon (Ach.) Thell - Common on rock, less often on humus over rock, in a variety of topographic positions from exposed bird perches to sheltered overhangs.

Melanelia stygia (L.) Essl. - Common on rock, stones, and gravel.

Melanohalea exasperatula (De Not.) O. Blanco et al. - Katmai: Camp at west end of Malone Lake, on twig, Picea glauca, McCune 34108. Lake Clark: near mouth of Horn Creek E of Chinitna Ranger Station, partial shade, mesic, Alnus bark on bole, Walton 19145; Tlikakila River drainage into Lake Clark, on Picea glauca twig, Walton 16603.

Melanohalea infumata (Nyl.) O. Blanco et al. - Lake Clark: bay on SW side of Portage Lake, on rock, lakeshore, McCune 35143, Walton 19128; Camel's Hump on shore of Lake Clark, on rock, Walton 19123; near outlet of Turquoise Lake, on lakeshore boulder, McCune 35101.

Melanohalea multispora (A. Schneider) O. Blanco et al. - Katmai: Headwaters Creek, SW of Malone Lake, on bark, Populus, McCune $34181 b$.

Melanohalea olivacea (L.) O. Blanco et al. - Common on bark, especially of Betula and Alnus, also on Picea, Populus, and Salix.

Melanohalea olivaceoides (Krog) O. Blanco et al. - Tuxedni: Chisik Island, Alnus thicket, eastern coast of island, on Sorbus scopulina, Talbot 88063-X-17 (Talbot et al. 1992; not confirmed by us).

Melanohalea septentrionalis (Lynge) O. Blanco et al. - Common on bark of conifers, hardwoods, and shrubs.

Melanohalea trabeculata (Ahti) O. Blanco et al. - Occasional on bark, usually on Picea glauca twigs, also on Populus.

Micarea assimilata (Nyl.) Coppins - Tuxedni: Chisik Island, low herb snowbed, Talbot 936 (Talbot et al. 1992, not confirmed).

Micarea cinerea (Schaerer) Hedl. - Lake Clark: Chinitna Ranger Station, on conk, Nelson 14-252 (TLC: gyrophoric, 5-O-methylhiascic acids); Chinitna Bay Ranger Station, near site of prehistorical pit houses, on Alnus viridis bark, Tфnsberg 44419.

Micarea denigrata (Fr.) Hedl. - Tuxedni: Chisik Island, on wood cannery dock, Talbot 1258 (conidial stage, det. B. Coppins 1983; see additional notes in Talbot et al.1992).

Micarea incrassata Hedl. - Katmai: N end of ridge W of Contact Creek, on liverworts on soil, McCune 34090. Lake Clark: slopes and flats above Turquoise Lake, on soil and moss, frost boil, McCune 35025; near SW end of Pickerel Lake, on organic matter, Rosentreter 18640.

Micarea melaena (Nyl.) Hedl. - Katmai: near Brooks Camp, along road and trail toward viewing platforms, on soft wood of Picea log, Tonsberg 42599; corticolous at base of slightly overhanging face of trunk of Betula, Tфnsberg 42607b. Lake Clark: near Chinitna Ranger Station, on conk, Nelson 14-253 (TLC: no substances).

Micarea misella (Nyl.) Hedl. - Katmai: near Brooks Camp, S of Brooks River, along road and trail toward viewing platform, Tфnsberg $42603 c$.

Micarea paratropa (Nyl.) Alstrup - Lake Clark: shoulder of basin on E side of Saddle Mountain, on rock, stones in tundra, McCune 35450a; shoulder of mountain overlooking Tuxedni Bay, on metal-rich rock, McCune 35485.

Micarea prasina Fr. - Lake Clark: Chinitna Ranger Station, on wood, Picea snag, McCune 35537, 35538; Tфnsberg 44287 (TLC: micareic acid); corticolous on huge trunk of Picea, Tønsberg 44372 (TLC: micareic acid).

Miriquidica deusta (Stenh.) Hertel \& Rambold - Katmai: Shoreline near camp on north side of Mirror Lake, Muggia 086. Lake Clark: slopes and flats above Turquoise Lake, on rock, 
McCune 34946.

Miriquidica deusta var. picea M. P. Andreev - Katmai: N end of ridge W of Contact Creek, on rock, McCune 34098. TLC: lobaric acid.

Miriquidica instrata (Nyl.) Hertel \& Rambold - Lake Clark: slopes and flats above Turquoise Lake, on rock, McCune $35018 c$.

Miriquidica nigroleprosa (Vainio) Hertel \& Rambold - Katmai: ridge above Hammersly Lake, on rock in alpine tundra, McCune 32920. Lake Clark: shoulder of mountain overlooking Tuxedni Bay, on rock, McCune 35467, 35468.

Miriquidica subplumbea (Anzi) Cl. Roux - Katmai: shoreline near camp on north side of Mirror Lake, on rock, Muggia 086a; low rocky ridge NE of Mirror Lake, Muggia 081, 083 (all det. McCune). An additional specimen from the latter site (Muggia 085) seemed intermediate between $M$. subplumbea and $M$. leucophaea, but had a gray thallus. Lake Clark: slopes and flats above Turquoise Lake, on rock, McCune $35018 b$.

Montanelia disjuncta (Erichsen) Divakar et al. - Occasional on rock, low elevations to alpine.

Montanelia panniformis (Nyl.) Divakar et al. - Occasional on rock, low elevations to alpine.

Montanelia tominii (Ach.) Divakar - Lake Clark: shore of Lake Clark, stop 2, W of Hatchet Point, on lakeshore outcrop, McCune 35351.

Muellerella sp. - Katmai: ca. $200 \mathrm{~m}$ N of Mirror Lake camp, on Rhizocarpon, Muggia 183.

Muellerella pygmaea (Körber) D. Hawksw. - Katmai: shoreline near camp on north side of Mirror Lake, on sterile lecideoid crust, Muggia 187.

Muellerella ventosicola (Mudd) D. Hawksw. - Katmai: low rocky ridge NE of Mirror Lake, on Ophioparma, Muggia 147.

Multiclavula vernalis (Schwein.) R. Petersen - Occasional on mineral soil.

Mycobilimbia carneoalbida (Müll. Arg.) Ekman \& Printzen - Lake Clark: Tanalian Falls SE of Port Alsworth, on Populus bark, Rosentreter 18483; over moss on a thick layer of humus under overhanging rock wall, Tфnsberg 43668.

Mycoblastus affinis (Schaerer) Schauer - Common on bark and wood of both hardwoods and conifers, low elevations to alpine. TLC (Tønsberg 42604c): atranorin, usnic, isousnic and planaic acids.

Mycoblastus sanguinarioides Kantvilas - Katmai: low rocky ridge NE of Mirror Lake, on rock (unusual substrate), Muggia 151 (det. McCune). Lake Clark: near Chinitna Bay Ranger Station, on Betula bark, McCune 35666; on Picea, McCune 35568.

Mycoblastus sanguinarius (L.) Norman - Common on bark and wood of both hardwoods and conifers at low elevations.

Mycocalicium subtile (Pers.) Szatala - Katmai: shore of Naknek Lake, bay just N of Brooks Camp, below crumbling outcrops, on dead Betula, Nelson 13-238. Lake Clark: near Chinitna Bay Ranger Station, on wood of conifer snag, McCune 35664a.

Myriolecis dispersa (Pers.) Śliwa, Zhao Xin \& Lumbsch - Katmai: shoreline of Naknek Lake on peninsula NE of Brooks Camp, Tønsberg 42704a (Tønsberg TLC: no substances), Muggia 011, 022. Lake Clark: shore of Chinitna Bay, ca. 4 km ENE of Chinitna Ranger Station, on rock, sandstone boulder on shoreline, McCune 35638b. The Lecanora dispersa group has been reassigned to Myriolecis (Zhao et al. 2016).

Myriolecis dispersa group - Unknown species apparently parasitic or saprophytic on cyanobacteria.) Lake Clark: summit of Slope Mountain, overlooking Tuxedni Channel, on rock, argillite, McCune 35417. Our collections originally identified as L. dispersa have mostly been shifted to L. semipallida according to Arup's identifications.

Myriolecis invadens (H. Magn.) Śliwa, Zhao Xin \& Lumbsch - Katmai: shoreline of Naknek Lake on peninsula NE of Brooks Camp, on lichens on lakeshore rock, McCune 32826b. Lake Clark: bay on SW side of Portage Lake, on rock, McCune 35161.

Myriolecis semipallida (H. Magn.) Śliwa, Zhao Xin \& Lumbsch - Katmai: Shoreline of Naknek Lake on peninsula NE of Brooks Camp; Tønsberg 42716. Lake Clark: NW end of Turquoise Lake, on cyanobacteria on lakeshore rock McCune 35072a; on caribou antler, Tonsberg 
43802; bay on W side of Portage Lake, on rock, McCune 35171 (all specimens det. Arup 2016).

Myriolecis zosterae - Katmai: Camp at west end of Malone Lake, on twig, Picea glauca, McCune 34111; shoreline of Naknek Lake on peninsula NE of Brooks Camp, on mosses over cliffs, McCune 32781 (extremely pruinose morph). These two specimens appear to belong to Lecanora zosterae var. palanderi (Vain.) Sliwa for which a new combination in Myriolecis has not been made.

Myrionora albidula (Willey) R. C. Harris - Katmai: ca. $600 \mathrm{~m} \mathrm{~S}$ of W end of Malone Lake, on dead Salix, Tonsberg 42952.

Myriospora hassei (Herre) K. Knudsen \& L. Arcadia - Lake Clark: shore of Chinitna Bay, ca. 4 km ENE of Chinitna Ranger Station, on sandstone boulder on shoreline, McCune 35629.

Myriospora smaragdula (Wahlenb. ex Ach.) Nägeli ex Uloth - Lake Clark: Camel's Hump on shore of Lake Clark, on cliff face, McCune 35299; Rosentreter 18767, det. Knudsen 2016.

Naetrocymbe punctiformis (Schrank) R.C. Harris - Lake Clark: shore of Chinitna Bay, ca. $3 \mathrm{~km}$ ENE of Chinitna Ranger Station, on Alnus bark, McCune 35652.

Nephroma arcticum (L.) Torss. - Occasional on tundra sod, moss, and bark on tree bases.

Nephroma bellum (Sprengel) Tuck. - Common on bark, most frequent on Populus and Salix, less often on Alnus, Betula, or Picea; low elevations to subalpine shrub thickets.

Nephroma expallidum (Nyl.) Nyl. - Occasional on tundra sod, moss, humus, and soil in forests to alpine tundra.

Nephroma helveticum Ach. (including N. helveticum subsp. sipeanum (Gyelnik) Goward \& Ahti) Occasional on Picea.

Nephroma isidiosum (Nyl.) Gyelnik - Occasional on bark of Alnus, Picea, and Populus at low elevations.

Nephroma parile (Ach.) Ach. - Common on bark and wood of both conifers and hardwoods; also common on moss over rock and rock, less often on soil; usually in partial shade in mesic sites.

Nephroma resupinatum (L.) Ach. - Occasional on bark of Alnus, Picea, Populus, and Salix at low elevations, partial shade in mesic sites.

Nephromopsis americana (Spreng.) Divakar, Crespo \& Lumbsch - Katmai: Occasional on Picea.

Nephromopsis andrejevii (Oxner) Divakar, Crespo \& Lumbsch - Common in alpine tundra, on humus and organic soil.

Nephromopsis chlorophylla (Willd.) Divakar, Crespo \& Lumbsch - Common on bark and wood.

Nephromopsis cucullata (Bellardi) Divakar, Crespo \& Lumbsch - Common on soil, humus, and humus over rock.

Nephromopsis inermis (Nyl.) Divakar, Crespo \& Lumbsch - Katmai: 900m NE of NE corner of Malone Lake., partial shade, mesic, shrub base, Walton 19112; SE of Nonvianuk River inlet,4 $\mathrm{km}$ from Backcountry Ranger's Cabin, partial shade, mesic, base of Betula shrub, Walton 19364. Lake Clark: SW corner of Telaquana Lake, $376 \mathrm{~m}$, partial shade, mesic, base of Betula shrub, Walton 19367; Old alluvial fan S of Twin Lakes connecting stream, partial shade, mesic, base of Betula shrub, Walton 19359.

Nephromopsis nivalis (L.) Divakar, Crespo \& Lumbsch - Common on humus, mineral soil, and tundra sod.

Normandina acroglypta (Norman) Aptroot - Lake Clark: shore of Chinitna Bay, ca. $3 \mathrm{~km}$ ENE of Chinitna Ranger Station, on Leptogium on trunks of large Populus balsamifera, Tonsberg 44385.

Normandina pulchella (Borrer) Nyl. - Occasional on lichens and mosses at low elevations, usually in partial shade in mesic sites.

Ochrolechia alaskana (Verseghy) Kukwa - Katmai: Alluvial flats near camp on E side of Hammersly Lake, on alpine sod, McCune 32959 (TLC: gyrophoric and variolaric acids); ridge above Hammersly Lake, Spickerman 205.

Ochrolechia androgyna (Hoffm.) Arnold s.1. - Common on wood, rock, and bark at low 
elevations.

Ochrolechia arborea (Kreyer) Almb. - Lake Clark: shore of Lake Clark, stop 2, W of Hatchet Point, on dead trunk of leaning Populus balsamea, Tonsberg 44144.

Ochrolechia aff. arborea (Kreyer) Almb. - Similar to O. arborea s. str. but lacking gyrophoric acid by TLC; thallus still UV+ yellowish orange. Katmai: Headwaters Creek, SW of Malone Lake, Tфnsberg 43000. Lake Clark: near west end of Portage Lake, on Populus balsamifera bark, McCune 35190.

Ochrolechia brodoi Kukwa - Lake Clark: 250 m NE of Chinitna Bay Ranger Station, near site of prehistorical pit houses, on Betula bark, McCune 35665 (det. Brodo 2015, new for North America (Brodo \& McCune 2017). Brodo TLC: gyrophoric, lecanoric (tr.), lichesterinic, and protolichesterinic acids.

Ochrolechia farinacea Howard - Katmai: Headwaters Creek, SW of Malone Lake, on Populus bark, McCune 34184.

Ochrolechia frigida (Sw.) Lynge - Common on alpine sod, plant detritus, soil, and those substrates over rock.

Ochrolechia gowardii Brodo - Lake Clark: near mouth of Horn Creek E of Chinitna Ranger Station, on Populus balsamifera, McCune 35608; near SW end of Pickerel Lake, on wood, Picea stump, McCune 35210.

Ochrolechia inaequatula (Nyl.) Zahlbr. - Katmai: Ridgetop W of Contact Creek, on alpine sod, Spickerman 67 (thallus $\mathrm{K}-, \mathrm{KC}+$ pink, $\mathrm{P}+$ orange-brownish).

Ochrolechia juvenalis Brodo - Katmai: near National Park Service bunkhouse in King Salmon, on Alnus bark, McCune 32712.

Ochrolechia mahluensis Räsänen - Katmai: near Brooks Camp, S of Brooks River, along road and trail toward viewing platform, on Betula bark, McCune 32733; Lake Clark: near SW end of Pickeral Lake, on Betula neoalaskana bark just above lakeshore beach, Tonsberg 43987; lignicolous on branch of Picea glauca, Tønsberg 43997; shore of Lake Clark ca. $30 \mathrm{~km}$ NE of Port Alsworth, W of Hatchet Point, lignicolous on snag of Picea glauca, Tonsberg 44120 (TLC: gyrophoric acid + satellites incl. lecanoric acid).

Ochrolechia oregonensis H. Magn. - Occasional on bark and wood, especially Picea, at low elevations.

Ochrolechia subpallescens Vers. - Lake Clark: shore of Chinitna Bay, ca. 3 km ENE of Chinitna Ranger Station, on Populus, McCune 35647.

Ochrolechia subplicans subsp. hultenii (Erichsen) Brodo - Katmai: shoreline of Naknek Lake on peninsula NE of Brooks Camp, on rock, McCune 32786. Lake Clark: shore of Chinitna Bay, ca. $4 \mathrm{~km}$ ENE of Chinitna Ranger Station, on sandstone boulder on shoreline, McCune 35637; summit of Slope Mountain, overlooking Tuxedni Channel, on rock, McCune 35393.

Ochrolechia szatalaensis Vers. - Occasional, mainly on Populus bark.

Ochrolechia upsaliensis (L.) A. Massal. - Lake Clark: bay on SW side of Portage Lake, on plant detritus over rock, McCune 35150; over moss on cliff wall $4 \mathrm{~m}$ from and facing lake, Tфnsberg 43934a (TLC: variolaric acid, 2 fatty acids in solvent C); shore of Lake Clark, stop 2, W of Hatchet Point, on moss over cliff, McCune 35342.

Ochrolechia sp. 1 - Lake Clark: on Betula bark, steep slope above small pond, Tфnsberg 44038; TLC: gyrophoric and variolaric acids. Only apothecial disk $\mathrm{C}+$ pink; keys out as $O$. juvenalis or O. subathallina in Brodo's key; but doesn't fit morphologically.

Ophioparma lapponica (Räsänen) Hafellner \& R. W. Rogers - Katmai: Lake Clark: slopes and flats above Turquoise Lake, on rock, McCune 34991.

Ophioparma ventosa (L.) Norman - Katmai: alpine ridge above Hammersly Lake, Muggia 053, 061; ca. $300 \mathrm{~m} \mathrm{~S}$ of W end of Malone Lake, Muggia 123; ca. $1 \mathrm{~km} \mathrm{SW}$ of Malone Lake, Spickerman 258; low rocky ridge NE of Mirror Lake, Muggia 147, 148, 149, Spickerman 76. Lake Clark: summit of Slope Mountain, overlooking Tuxedni Channel, on rock, McCune 35373. Tuxedni: Chisik Island, low herb snowbed, on Boulder, Talbot 773A, 768 (originally det. H. lapponicum, Talbot et al. 1992). 
Orphniospora moriopsis (A. Massal.) D. Hawksw. - Katmai: low rocky ridge NE of Mirror Lake, on rock, McCune 32990; ridgetop W of Contact Creek, on granite, McCune 34064a, McCune 34072. Lake Clark: slopes and flats above Turquoise Lake, on rock, McCune 35014.

Pachypeltis castellana (Räsänen) Søchting, Frödén \& Arup - Lake Clark: bay on SW side of Portage Lake, on rock, McCune 35169a; shore of Lake Clark, stop 2, W of Hatchet Point, on rock, wetted lakeshore, McCune 35355.

Palicella filamentosa (Stirt.) Rodr. Flakus \& Printzen - Katmai: Headwaters Creek, SW of Malone Lake, on Alnus bark, Spickerman 227; near National Park Service bunkhouse in King Salmon, on bark, Alnus, McCune 32720.

Pannaria conoplea (Ach.) Bory - Lake Clark: Chinitna Ranger Station, on Populus trunk, McCune 35591 .

Parmelia fraudans (Nyl.) Nyl. - Lake Clark: North shore of Tuxedni River, on granite cliff, Dillman KD 2003-1223 (Dillman 2003); shoulder of mountain overlooking Tuxedni Bay, on shaded rock, Walton 19117.

Parmelia hygrophila Goward \& Ahti - Occasional on bark of Alnus, Betula, and Picea at low elevations, also on wood and rock. Tuxedni: misidentified as Punctelia subrudecta and Parmelia saxatilis by Talbot et al. (1992): Talbot 1362, 1371A, 1372A.

Parmelia omphalodes (L.) Ach. - Common on rock, moss and detritus over rock, humus, and alpine sod.

Parmelia pseudosulcata Gyelnik - Lake Clark: Chinitna Ranger Station, Rosentreter 18895.

Parmelia saxatilis (L.) Ach. - Common on rock, bark, and wood, low elevations to alpine.

Parmelia skultii Hale - Lake Clark: bay on SW side of Portage Lake, on soil and moss over rock, McCune 35131.

Parmelia squarrosa Hale - Occasional on bark, mainly of Picea, also Betula, Populus, and Salix, at low elevations.

Parmelia sulcata Taylor - Very common on bark and wood of all species, infrequently on rock.

Parmelia sp. - Lake Clark: Camel's Hump on shore of Lake Clark, on cliff face, McCune 35280 (unusual combination of squarrose rhizines, granular isidia, and pruinose upper cortex).

Parmeliella parvula P. M. Jørg. - Katmai: near Brooks Camp, S of Brooks River, along road and trail toward viewing platform, Tфnsberg 42623 (det. P. M. Jørgensen 2014); near shore of Naknek Lake, N of Brooks Camp, Tфnsberg 42637; on Populus balsamifera, Nelson 13-176; $\mathrm{S}$ shore Naknek L. near Grandma's Rock about $5 \mathrm{~km}$ from boat launch, on Populus balsamifera, Nelson 13-42. Lake Clark: Chinitna Ranger Station, on bark, trunk of Picea

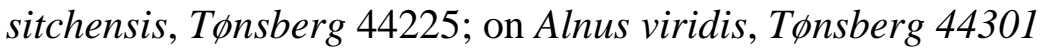

Parmeliella triptophylla (Ach.) Müll. Arg. - Occasional on Populus balsamifera at low elevations; also on rock.

Parmeliopsis ambigua (Wulfen) Nyl. - Common on bark wand wood.

Parmeliopsis hyperopta (Ach.) Arnold - Occasional on bark, wood, and rotting logs.

Parvoplaca sp. - Lake Clark: shore of Lake Clark, stop 2, W of Hatchet Point, on fallen trunk of Populus balsamifera, Tønsberg 44132; SW end of Pickerel Lake, on bark, McCune 35218 (both det. Arup 2016)

Parvoplaca nigroblastidiata Arup, Halici \& Vondrák - Katmai: ca. $1 \mathrm{~km} \mathrm{SW}$ of Malone Lake, Tønsberg 42982b, 42983 (Arup et al. 2015, GenBank KC179113).

Peltigera aphthosa (L.) Willd. s.l. - Common on soil, moss, humus, Sphagnum hummock, forest floor. Morphological polymorphisms in P. aphthosa s.l. have no clear correspondence to the potential multiple phylogenetic species (DNA numbers: P4000, P4002). As currently delimited, $P$. aphthosa is a multispecies complex; however, based on the most recent multilocus phylogeny, $P$. britannica is embedded in this broadly defined clade. At present the taxonomy of the complex is left unchanged, because none of its internal clades is well supported and well circumscribed morphologically (except for $P$. britannica).

Peltigera britannica (Gyelnik) Holt.-Hartw. \& Tønsberg - Common on soil, moss, and tree bases.

Peltigera canina (L.) Willd. - Katmai: near Brooks Camp, S of Brooks River, along road and trail 
toward viewing platform, Spickerman 133a. (DNA number: P4007). Lake Clark: near campsite at NW end of Turquoise Lake, Walton 19287. Although P. canina is to be split into several species, the collections examined will remain as P. canina s. str. (Magain et al. 2018).

Peltigera collina (Ach.) Schrader - Common on bark and wood of both hardwoods and conifers, also on forest floor and mossy rock. In some cases the lobe margins and stress cracks were very lobulate but also with coarse soredia.

Peltigera aff. degenii Gyelnik "P. degenii 3" - Katmai: near shore of Naknek Lake, N of Brooks Camp, Spickerman 131; DNA P4010. This potentially new species is restricted to Asia and Katmai, the only locality in North America (Magain et al. 2018).

Peltigera didactyla (With.) J. R. Laundon - Occasional on mineral soil and moss. One specimen (Spickerman 199) is a potential new undescribed species " $P$. didactyla 2" with a widespread distribution (Magain et al. 2018); DNA P4013.

Peltigera elisabethae Gyelnik - Lake Clark: Camel's Hump on shore of Lake Clark ca. $10 \mathrm{~km} \mathrm{NE}$ of Port Alsworth, on cliff face, McCune 35269; shore of Lake Clark W of Hatchet Point, on moss over boulder, McCune 35311.

Peltigera extenuata (Vainio) Lojka - Common on moss and humus and those substrates over rock. Peltigera horizontalis (Hudson) Baumg. - Occasional on humus or moss over soil or rock.

Peltigera latiloba Holt.-Hartw. Katmai: gravel road between Naknek Lake and Lake Brooks, Picea glauca forest, Spickerman 123 (DNA 4001). This member of the P. aphthosa group (HoltanHartwig (2005), previously discussed as "Peltigera sp. 1" (Holtan-Hartwig 1993), is has been reported from three unspecified localities in Alaska (Holtan-Hartwig 1993) and White Pass (Spribille et al 2010). The ITS of P4001 clearly suggests $P$. latiloba but the morphology does not match $P$. latiloba (not hairy toward the center). The status of this taxon is not resolved; $P$. leucophlebia could be taken as one broadly defined species with varieties, including latiloba, corresponding to each molecular clade. We do not see consistent synapomorphic characters defining each clade.

Peltigera lepidophora (Nyl. ex Vainio) Bitter - Occasional on moss on shrub base, rood wad, and rock crevice.

Peltigera leucophlebia (Nyl.) Gyelnik s.l. - Common on humus, soil, and moss. The material includes P. leucophlebia s.str. (DNA P4003 and P4014). These two specimens represent clade which contains many European specimens.

Peltigera malacea (Ach.) Funck - Common on soil, humus, and moss or those substrates over rock (Spickerman 147, DNA 4004). As currently delimited P. malacea contains at least five potential species recognized by various species delimitation and verification methods but it will not be formally divided. The group is monophyletic and no morphological, chemical, or geographical characteristics define these potential species).

Peltigera membranacea (Ach.) Nyl. - Common on soil, humus, moss, and bark. DNA 4009. Also present in Tuxedni but reported as P. canina (Talbot et al. 1992).

Peltigera monticola Vitik. - Katmai: on forest floor, Walton 18677 (det. Miadlikowska 2014, P. monticola/ponojensis complex; this complex will be split in several species (Magain et al. 2018).

Peltigera neckeri Hepp ex Müll. Arg. - Occasional, low elevations alpine tundra in Katmai. Not yet recorded from Lake Clark.

Peltigera neorufescens Miadl. et al. ined., - Katmai: Katmai Bay, $57.9951^{\circ} \mathrm{N}-155.0279^{\circ} \mathrm{W}, 15 \mathrm{~m}$, on soil on large cliff near ocean beach, Walton 18669, DNA P6150. See Miadlikowska \& Lutzoni (2000).

Peltigera occidentalis (A.E. Dahl) Kristinsson - Katmai: ca. 1km SW of Malone Lake, lichen woodland with large granite boulders and clumps of Picea, Spickerman s.n.

Peltigera neopolydactyla (Gyelnik) Gyelnik s.l. - Common on forest floor, humus, moss, and tree bases. The material is heterogeneous, falling in several lineages (Magain et al. 2017a, 2017b) as summarized in Table 6.

Peltigera polydactylon (Necker) Hoffm. subsp. udeghe Magain, Miadl. \& Sérus. (Magain DNA 
P4011) - Katmai: NE side of Malone Lake, Spickerman 177. On soil, humus, Sphagnum, moss over ground, forests to alpine tundra. This is the North American/Asian clade, distinct from the European clade (Magain et al. 2016). It is widespread in western North America.

Table 6 Lineages of the Peltigera neopolydactyla group in the study area.

\begin{tabular}{|l|l|l|l|l|}
\hline Clade name & Species ined. & Parks & $\begin{array}{l}\text { DNA } \\
\text { Number }\end{array}$ & Example specimens \\
\hline P. neopolydactyla 1 & P. appalachensis & Tuxedni & $\begin{array}{l}\text { P3124, } \\
\text { P3125 }\end{array}$ & Talbot 860, Talbot 547 \\
\hline P. neopolydactyla 2 & P. vitikainenii & $\begin{array}{l}\text { Katmai, } \\
\text { Tuxedni }\end{array}$ & P4005 & $\begin{array}{l}\text { Spickerman 160, } \\
\text { Talbot 87020-19 }\end{array}$ \\
\hline P. neopolydactyla 5 & $\begin{array}{l}\text { P. sp., endemic to } \\
\text { Pacific NW }\end{array}$ & Tuxedni & $\begin{array}{l}\text { ID based on } \\
\text { morphology }\end{array}$ & $\begin{array}{l}\text { Talbot 87020-21, } \\
\text { Talbot 87020-34 }\end{array}$ \\
\hline
\end{tabular}

Peltigera ponojensis Gyelnik - Lake Clark: summit of Slope Mountain, overlooking Tuxedni Channel, on mineral soil over rock in snowy crevice, Walton 19288 (det. McCune).

Peltigera praetextata (Flörke ex Sommerf.) Zopf - Common on mineral soil, humus, forest floor, moss on tree bases, moss over rock, and forest floor, low elevations to alpine tundra.

Peltigera rufescens (Weiss) Humb. - Occasional on soil, rock, and tundra sod. Tuxedni: specimens identified as $P$. rufescens (Talbot et al. 1992) are a mixture of $P$. praetextata, $P$. cf. ponojensis, and $P$. polydactylon group.

Peltigera scabrosa Th. Fr. s.l. - Very common on soil, moss, humus, and humus over rock, low elevations to alpine tundra. Peltigera scabrosa s.l. contains multiple lineages; the material tested here corresponds to "P. scabrosa 2", which corresponds to P. scabrosa s. str. "P. scabrosa" was identified morphologically from Tuxedni (Talbot 88010-41, 956), but the material was too old for sequencing.

Peltigera aff. scabrosa Th. Fr - Katmai: low rocky ridge NE of Mirror Lake, Spickerman 198 (an undescribed species; this is the only locality, but the ITS is very different from the remaining species in P. scabrosa complex; DNA P4015).

Peltigera aff. scabrosella Holt.-Hartw. - Katmai: above Hammersly Lake, alpine, Spickerman 139 (undescribed species within P. scabrosella s.l.; DNA P4006). This species is phylogenetically closely related to $P$. scabrosella but morphologically similar to $P$. neopolydactyla.

Peltigera venosa (L.) Hoffm. - Common on soil and moss or those substrates over rock; less often on old wood.

Pertusaria sp. - Lake Clark: near mouth of Horn Creek E of Chinitna Ranger Station, on Alnus branch, McCune 35622 (TLC: stictic acid, several xanthones).

Pertusaria alaskensis Erichsen - Katmai: shoreline of Naknek Lake on peninsula NE of Brooks Camp, on shady cliff, McCune 32799. - Lake Clark: bay on SW side of Portage Lake, on rock, McCune 35151a.

Pertusaria alpina Hepp ex Ahles - Tuxedni: Chisik Island; 0.5 miles north of Cannery, on Alnus crispa, Talbot $302 \mathrm{~A}$.

Pertusaria borealis Erichsen - Common on bark of Alnus and Betula, less often on Salix.

Pertusaria bryontha (Ach.) Nyl. - Lake Clark: near outlet of Turquoise Lake, on tundra sod, McCune 35116; bay on SW side of Portage Lake, on organic matter, Rosentreter 18622. Disk pale pinkish orange (Ochrolechia-like), spores 1/ascus (consistently), about $150 \times 50 \mu \mathrm{m}$; hymenium and epithecium $\mathrm{C}+$ pink, cortex $\mathrm{C}+$ yellow, $\mathrm{UV}-$; epithecium $\mathrm{K}-$ or with pale yellow diffusion. According to I. M. Brodo (pers. comm.), this is an odd morph of $P$. bryontha that agrees with descriptions of the species in every respect (thallus and apothecial type, spores, chemistry, substrate, and distribution) except one: disk color and epihymenial $\mathrm{K}$ reaction. TLC: gyrophoric acid, stictic acid, and a xanthone.

Pertusaria carneopallida (Nyl.) Anzi - Occasional on Alnus and Salix, low elevations to alpine. 
Pertusaria coriacea (Th. Fr.) Th. Fr. - Lake Clark: bay on SW side of Portage Lake, on wood, Rosentreter 18628.

Pertusaria dactylina - see Lepra

Pertusaria excludens - see Lepra

Pertusaria geminipara (Th. Fr.) C. Knight ex Brodo - Occasional on soil, moss, or organic matter in alpine tundra.

Pertusaria glaucomela (Tuck.) Nyl. - Common on Picea twigs, less often on Alnus, at low elevations. TLC on three specimens from Lake Clark (Tønsberg 43722, 44291 \& 44321): gyrophoric acid (major) and traces of two, probably satellite substances.

Pertusaria glomerata (Ach.) Schaerer - Katmai: shore of Naknek Lake, bay just N of Brooks Camp, below crumbling outcrops, on Populus balsamifera, McCune 32888.

Pertusaria hymenea (Ach.) Schaerer - Tuxedni: Chisik Island, on Populus trichocarpa, Talbot 88052-X-46 (Talbot et al. 1992 as P. xanthostoma).

Pertusaria lactea - see Varicellaria

Pertusaria leucostoma (Bernh.) A. Massal. - Tuxedni: Chisik Island, on Alnus crispa, Talbot 87001-31, Talbot 87001-33 (Talbot et al. 1992).

Pertusaria oculata (Dickson) Th. Fr. - Common on detritus, rocky soil, and tundra sod.

Pertusaria cf. oculata (Dickson) Th. Fr. - Lake Clark: shoulder of basin on E side of Saddle Mountain, on rocky soil, McCune 35430; TLC: protocetraric only (new chemotype); epihymenium $\mathrm{K}+$ violet, so cannot be $P$. dactylina. See also Pertusaria sp. below.

Pertusaria panyrga - see Lepra

Pertusaria aff. pupillaris (Nyl.) Th. Fr. - Katmai: near Brooks Camp, S of Brooks River, along road and trail toward viewing platform, Tønsberg 42581 (TLC: fumarprotocetraric acid, trace protocetraric acid).

Pertusaria sommerfeltii (Flörke ex Sommerf.) Fr. - Occasional on bark of Alnus, Populus, and Salix, low elevations to alpine. TLC of Tonsberg 42925: stictic acid, two xanthones, fatty acid.

Pertusaria subdactylina Nyl. - Lake Clark: near campsite at NW end of Turquoise Lake, on sloping soil bank at inner edge of lakeside beach, Tonsberg 43857; on soil among pebbles, Tфnsberg 43729a; Lake Clark: slopes and flats above Turquoise Lake, on rock, McCune 34994 (TLC: hypothamnolic + unk. Rf A1C2); on humus and detritus on the ground, Tønsberg 43780.

Pertusaria subobducens Nyl. - Common on a wide array of substrates: rock, humus, soil and moss over rock, wood, plant detritus, Alnus, and mossy rock wall facing falls.

Pertusaria trochiscea Norman - Lake Clark: bay on SW side of Portage Lake, on wood, decorticate, Rosentreter 18598.

Pertusaria sp. - Lake Clark: summit of Slope Mountain, overlooking Tuxedni Channel, on windexposed, \pm vertical soil bank rich in humus, Tønsberg 44174. The specimen is similar to $P$. oculata, but without isidia; TLC: fumarprotocetraric (major) and protocetraric acids; no gyrophoric acid.

Phaeocalicium compressulum (Nyl. ex Szatala) A. F. W. Schmidt - Katmai: shoreline of Naknek Lake on peninsula NE of Brooks Camp, on bark of Alnus crispa, McCune 32830. Lake Clark: near mouth of Horn Creek E of Chinitna Ranger Station, on Alnus twig, McCune 35610; Nelson 14-500.

Phaeocalicium populneum (Brond. ex Duby) A. F. W. Schmidt - Katmai: near shore of Naknek Lake, N of Brooks Camp, on Populus twigs, McCune 32766. Lake Clark: shore of Chinitna Bay, ca. $3 \mathrm{~km}$ ENE of Chinitna Ranger Station, on Populus balsamifera twigs, McCune 35644.

Phaeocalicium praecedens (Nyl.) A. F. W. Schmidt - Katmai: ca. $600 \mathrm{~m} \mathrm{~S}$ of W end of Malone Lake, on Salix twigs, McCune 34135.

Phaeophyscia ciliata (Hoffm.) Moberg - Occasional on Populus at low elevations.

Phaeophyscia constipata (Norrlin \& Nyl.) Moberg - Lake Clark: $60.48045^{\circ} \mathrm{N}, 154.08194^{\circ} \mathrm{W}, 1003$ 
$\mathrm{m}$, on moss, Walton 16454b; on alpine tundra, Walton 16463; shore of Lake Clark, W of Hatchet Point, on moss and soil over rock, McCune 35314, Walton 19118. Not recorded from Katmai.

Phaeophyscia decolor (Kashiw.) Essl. - Lake Clark: bay on SW side of Portage Lake, on rock and moss over rock, lakeshore, McCune 35144, 35162, McCune 35166; NW end of Turquoise Lake, on moss over rock, Rosentreter 18579; outlet of Turquoise Lake, on moss, Rosentreter 18585.

Phaeophyscia erythrocardia (Tuck.) Essl. - Tuxedni: Chisik Island, on Populus trichocarpa, Talbot 88052-V-20 (det. Esslinger 2016; previously listed as P. hirtella by Talbot et al. (1992).

Phaeophyscia hirsuta (Mereschk.) Essl. - Occasional on Populus, less often on Alnus, at low elevations.

Phaeophyscia hispidula (Ach.) Essl. - Lake Clark: shore of Lake Clark, W of Hatchet Point, on boulder side, Walton 19136.

Phaeophyscia kairamoi (Vainio) Moberg - Common on rock and bark, especially Populus.

Phaeophyscia orbicularis (Necker) Moberg - Katmai: shore of Naknek Lake, bay just N of Brooks Camp, on Salix, McCune 32869.

Phaeophyscia pusilloides (Zahlbr.) Essl. - Tuxedni: Chisik Island, Alnus thicket, eastern coast of island, on Sorbus scopulina, Talbot $88063-X-9 B, 88063-X-21$ (previous listed as $P$. orbicularis by Talbot et al. (1992).

Phaeophyscia sciastra (Ach.) Moberg - Common on rock or moss or plant detritus over rock, low elevations to alpine tundra.

Phaeopyxis punctum (A. Massal.) Rambold, Triebel \& Coppins - Lake Clark: Chinitna Ranger Station, on wood of Picea snag, Tфnsberg 44402.

Phaeorrhiza nimbosa (Fr.) H. Mayrh. \& Poelt - Lake Clark: bay on SW side of Portage Lake, on soil, Rosentreter 18618.

Phlyctis argena (Sprengel) Flotow - Lake Clark: Chinitna Ranger Station, on Alnus, Tønsberg 44199, 44361; on Picea sitchensis, Tonsberg 44231; SW end of Pickerel Lake, on Alnus viridis, Tфnsberg 44019.

Phylliscum demangeonii (Moug. \& Mont.) Nyl. - Katmai: ca. $200 \mathrm{~m} \mathrm{~N}$ of Mirror Lake camp, on rock, Muggia 175.

Physcia adscendens (Fr.) H. Olivier - Katmai: Katmai Bay Bear Cam, 58.0048 $\mathrm{N}, 155.0442^{\circ} \mathrm{W}, 18$ m, on Populus balsamifera bark on bole, Walton 18595. Lake Clark: low ridge above inlet stream to Pickerel Lake, on Picea twigs, Rosentreter 18660.

Physcia aipolia (Ehrh. ex Humb.) Fürnr. - Numerous records from this area, including Talbot et al. (1992) are presumably all referable to P. alnophila.

Physcia alnophila (Vainio) Lohtander et al. - Common on bark, especially Alnus, Populus, and Salix at low elevations.

Physcia biziana (A. Massal.) Zahlbr. - Lake Clark: Camel's Hump on shore of Lake Clark, on cliff face, McCune 35295.

Physcia caesia (Hoffm.) Fürnr. - Occasional on rock, especially lakeshore outcrops, rarely on driftwood.

Physcia phaea (Tuck.) J. W. Thomson - Occasional on rock, low elevations to lakeshore rock in alpine tundra.

Physcia tenella (Scop.) DC. - Katmai: S shore Naknek Lake near $1.3 \mathrm{~km} \mathrm{~S}$ of Gull Island, on Salix, Nelson 13-108; Naknek Lake on peninsula NE of Brooks Camp, on lakeside cliff, McCune 32814. Lake Clark: bay on SW side of Portage Lake, on rock, McCune 35164.

Physciella chloantha (Ach.) Essl. - Katmai: $57.9972^{\circ} \mathrm{N}, 155.0270^{\circ} \mathrm{W}$, large cliff area near ocean beach, on cliff face, Walton 18659 (det. Esslinger).

Physconia americana Essl. - Katmai: shoreline of Naknek Lake on peninsula NE of Brooks Camp, on rock, shady cliff, McCune 32803. Lake Clark: trail to Tanalian Falls from Port Alsworth, on bark, Rosentreter 18503. 
Physconia detersa (Nyl.) Poelt - Common on Alnus and Populus, also on Picea, Salix, and rock at low elevations. Tuxedni: specimens reported under this name in Talbot et al. (1992) are $P$. enteroxantha, $P$. grumosa, and $P$. perisidiosa.

Physconia grumosa Kashiw. \& Poelt - Common on Populus bark at low elevations.

Physconia labrata Essl., McCune \& Haughland - Katmai: shore of Naknek Lake, bay just N of Brooks Camp, below crumbling outcrops, on Populus balsamifera, McCune 32886a. Lake Clark: near west end of Portage Lake, on Populus balsamifera, McCune 35181. This species is also known from other localities in the boreal zone in North America, as well as in Asia (Esslinger et al. 2017; see this paper for key to species).

Physconia muscigena (Ach.) Poelt - Common on soil and moss over rock, low elevations to alpine.

Physconia perisidiosa (Erichsen) Moberg - Common on hardwoods, especially Populus bark, also on moss over rock.

Piccolia ochrophora (Nyl.) Hafellner - Katmai: ca. $300 \mathrm{~m} \mathrm{~S}$ of $\mathrm{W}$ end of Malone Lake, overgrowing an unidentified crustose cyanolichen on bark of dead Salix (shrub), Tønsberg 42925 (as an associate of Pertusaria sommerfeltii; spores spherical, 2-4 $\mu \mathrm{m}$ diam.).

Pilophorus sp. Pino Bodas ined. - Katmai: $200 \mathrm{~m}$ N of Mirror Lake camp, on shaded vertical face of boulder in fell-field, Tønsberg 42843 (TLC: atranorin, stictic acid, and traces of terpenoids). Lake Clark: shoulder of mountain overlooking Tuxedni Bay, on pebbles, Tønsberg 44277, 44250 (TLC: atranorin, stictic acid + 5 satellites, fatty acid at C5-6, unknown at B8).

Pilophorus nigricaulis Satô - Occasional on rock outcrops, sheltered rock faces, and stones in tundra, full sun or shaded. Tønsberg 44282 confirmed by DNA sequence by Pino Bodas in 2018.

Pilophorus robustus Th. Fr. - Becharof National Wildlife Refuge, near Lake Becharof, $<20 \mathrm{~km}$ west of Katmai: 5803'19.6"N, 156¹8'46.7"W, 381 m, Empetrum nigrum-Vaccinium vitisidaea heath, on stone, 7 Aug 1998, Talbot 98-149-X-1 (UBC, det. Goward; not seen by us.)

Pilophorus vegae Krog - Katmai: low rocky ridge NE of Mirror Lake, Tønsberg 42822, 42827, confirmed by DNA sequence by Pino Bodas in 2018.

Placidium lachneum (Ach.) B. de Lesd. - Lake Clark: shore of Lake Clark W of Hatchet Point, on soil, Rosentreter 18793; campsite at NW end of Turquoise Lake, on noncalcareous lakeshore rock, McCune 35084.

Placidium pilosellum (Breuss) Breuss - Lake Clark: bay on SW side of Portage Lake, on soil, Rosentreter 18616.

Placidium squamulosum (Ach.) Breuss - Lake Clark: shore of Lake Clark, W of Hatchet Point, on soil, Rosentreter 18800.

Placopsis cribellans (Nyl.) Räsänen - Katmai: shoreline of Naknek Lake on peninsula NE of Brooks Camp, Muggia 008, 009. Lake Clark: shore of Chinitna Bay, ca. $4 \mathrm{~km}$ ENE of Chinitna Ranger Station, on rock, sandstone boulder on shoreline, McCune 35631.

Placopsis gelida (L.) Lindsay s.l. - Katmai: shoreline of Naknek Lake on peninsula NE of Brooks Camp, on rock, McCune 32789 (TLC: gyrophoric acid). Lake Clark: shoulder of basin on E side of Saddle Mountain, on rock, Rosentreter 18850; on pebbles in late snowbed, Tønsberg 44187 (TLC: gyrophoric acid (major), lecanoric acid).

Placopsis roseonigra Brodo - Katmai: alpine ridge above Hammersly Lake, Tфnsberg 42780b (TLC: gyrophoric acid (major), lecanoric acid). Lake Clark: shoulder of mountain overlooking Tuxedni Bay, on pebbles, Tønsberg 44251. In addition to the substances given by Brodo (1995), this specimen contained 5-O-methylhiascic acid.

Placopsis sulcata Spribille ined. - Katmai: ca. $200 \mathrm{~m}$ N of Mirror Lake camp, Muggia 169, 170; ridgetop W of Contact Creek, Muggia 100; all det. T. Spribille 2016.

Placynthiella dasaea (Stirt.) Tønsberg - Lake Clark: Trail to Tanalian Falls from Port Alsworth, on burnt wood, Tønsberg 43656; TLC: gyrophoric (major) and lecanoric acids.

Placynthiella icmalea (Ach.) Coppins \& P. James - Occasional on wood, moss, humus, bark, and 
soil, low elevations to alpine tundra.

Placynthiella oligotropha (J. R. Laundon) Coppins \& P. James - Lake Clark: low ridge above inlet stream to Pickerel Lake, on wood, Rosentreter 18665; W side of Turquoise Lake, on steep, organic soil bank facing pond, Tonsberg 43867.

Placynthiella uliginosa (Schrader) Coppins \& P. James - Occasional on soil, organic matter, logs. Not recorded from Katmai, but most likely there, based on its wide distribution and broad ecological tolerances.

Placynthium asperellum (Ach.) Trevisan - Lake Clark: bay on SW side of Portage Lake, on rock, Rosentreter 18615; shore of Lake Clark, W of Hatchet Point, on $\mathrm{HCl}+$ rock, McCune 35307a.

Placynthium flabellosum (Tuck.) Zahlbr. - Katmai: midslope below ridge above Hammersly Lake, Tфnsberg 42786 (det. P.-M. Jørgensen 2014); shoreline near camp on E side of Hammersly Lake, on shoreline cobbles, McCune 32974, 32975; shoreline near camp on north side of Mirror Lake, on boulder on beach, McCune 34013, 34015b, Muggia 190. Lake Clark: small drainage on slope above NW side of Turquoise Lake, on rock by stream, McCune 35040; Tanalian Falls SE of Port Alsworth, on granite, Rosentreter 18479.

Placynthium nigrum (Hudson) Gray - Lake Clark: bay on SW side of Portage Lake, on rock, wetted lakeshore boulder, McCune 35140.

Placynthium pannariellum (Nyl.) H. Magn. - Lake Clark: near trail to Tanalian Falls from Port Alsworth, on rock, McCune 34933.

Placynthium rosulans (Th. Fr.) Zahlbr. - Katmai: Headwaters Creek, SW of Malone Lake, on rock, dark outcrop by creek, McCune 34205 .

Placynthium tantaleum (Hepp) Hue - Lake Clark: campsite at NW end of Turquoise Lake, on lakeshore rock, McCune 35057a, 35058.

Platismatia glauca (L.) Culb. \& C. Culb. - Common on bark and wood at low elevations.

Platismatia lacunosa (Ach.) Culb. \& C. Culb. - Katmai: $58.0048^{\circ} \mathrm{N}, 155.0443^{\circ} \mathrm{W}, 18 \mathrm{~m}$, partial shade, mesic, on Betula neoalaskana, Walton 18522.

Platismatia norvegica (Lynge) Culb. \& C. Culb. - Occasional, mainly on conifers, also on Betula; low elevation forests and woodlands.

Pleopsidium flavum (Bellardi) Körber - Lake Clark: Camel's Hump on shore of Lake Clark ca. 10 km NE of Port Alsworth, Rosentreter 18775, det. Knudsen 2016.

Polyblastia septentrionalis Lynge - Lake Clark: slopes and flats above Turquoise Lake, on rock, loose stones, McCune 34971.

Polycauliona candelaria (L.) Frödén, Arup \& Søchting s.l. - Locally common in eutrophic microsites, on bark, wood, bird perch rocks; rock, cobbles, pebbles and detritus on beach ridge. Some of this material (e.g. McCune 32708, 32961a, 34002) is likely Polycauliona sp. nov. aff. candelaria. This is perhaps an undescribed species that looks like a strange $P$. candelaria. Genetically it is closer to P. polycarpa, but is blastidiate.

Polycauliona polycarpa (Hoffm.) Frödén, Arup \& Søchting - Katmai: Brooks Lodge area (Schindler 1990), Kukak Bay, on Coville \& Kearney, 1515 b (Cummings 1904). Lake Clark: near Pickerel Lakes, on Salix glauca bark, Walton 16843.

Polycauliona sp. - Katmai: Katmai Bay Creek, 57.9898 N, $155.0309^{\circ} \mathrm{W}, 24 \mathrm{~m}$, on Salix, Walton 18670 (det. Arup 2018).

Polychidium muscicola (Sw.) Gray - Common on bryophytes over rock.

Porocyphus coccodes (Flotow) Körber - Lake Clark: near campsite at NW end of Turquoise Lake, on lakeshore rock, McCune 35051, 35057b.

Porpidia cinereoatra (Ach.) Hertel \& Knoph - Lake Clark: shoulder of basin on E side of Saddle Mountain, on stones in tundra, McCune 35454; shoulder of mountain overlooking Tuxedni Bay, on rock, McCune 35466; summit of Slope Mountain, overlooking Tuxedni Channel, on rock, McCune 35391. TLC: confluentic acid.

Porpidia contraponenda (Arnold) Knoph \& Hertel - Lake Clark: saddle on ridge near headwaters of Johnson River, on noncalcareous stones, McCune 35511; shoulder of basin on E side of Saddle Mountain, on stones in tundra, McCune 35453; TLC: methyl 2'-O- 
methylmicrophyllinate.

Porpidia crustulata (Ach.) Hertel \& Knoph - Katmai: alpine ridge above Hammersly Lake, on stone, Spickerman 58. Lake Clark: shoulder of basin on E side of Saddle Mountain, on rock by rivulet, McCune 35456; slopes and flats above Turquoise Lake, on rock, McCune 34997; small drainage on slope above NW side of Turquoise Lake, on rock by stream, McCune 35038 (TLC: nil); south end of Pickerel Lake, on stones, McCune 35261a (TLC: nil).

Porpidia flavocaerulescens (Hornem.) Hertel \& A. J. Schwab - Occasional on rock in alpine tundra. TLC (one specimen): confluentic acid. The morph with an orange thallus was conspicuous, but the white morph was also collected.

Porpidia grisea Gowan - Katmai: shoreline near camp on E side of Hammersly Lake, on rock, Muggia 134 (det. McCune; medulla I+ violet, spores about $10 \times 5.5 \mu \mathrm{m}$, exciple and hypothecium dark brown).

Porpidia melinodes (Körber) Gowan \& Ahti - Occasional on rock in alpine tundra, including loose stones, rock by stream, and dry fellfield.

Porpidia nigrocruenta (Anzi) Diederich \& Sérus. Lake Clark: summit of Slope Mountain, overlooking Tuxedni Channel, on loose rocks on bare soil, Tønsberg 44162c (det. A. Fryday 2015); TLC: stictic acid with satellites. The yellowish, $\mathrm{K}+$ red internal exciple is distinctive. Fryday (2005) treated this as a form of $P$. macrocarpa but he is now convinced that it is a good species (pers. comm. 2015).

Porpidia rugosa (Tayl.) Coppins \& Fryday - Lake Clark: Camel's Hump on shore of Lake Clark, on rock, cliff face, McCune 35276 (DNA: ITS GenBank KY800512; McCune et al. 2017); Tanalian Falls SE of Port Alsworth, on rock, McCune 34894a (DNA: ITS GenBank KY800511). Sterile whitish, lumpy crust; TLC: 2'-O-methylsuperphyllinic and glaucophaeic acids. DNA extracted, ITS match for both specimens with two specimens of $P$. rugosa from Ireland and Faroe Islands in GenBank (KJ162321, KJ162320).

Porpidia soredizodes (Lamy ex Nyl.) J. R. Laundon - Lake Clark: Tanalian Falls SE of Port Alsworth, on rock, submerged, McCune 34923. TLC: stictic acid.

Porpidia speirea (Ach.) Kremp. - Lake Clark: Tanalian Falls SE of Port Alsworth, on rock, McCune 34904. TLC: confluentic acid, 2'-O-methylmicrophyllinic acid, unknown Rf B'2 C1.

Porpidia thomsonii Gowan - Common on rock in many habitats, but especially common near lakes and streams and in alpine tundra. Tuxedni: Chisik Island, Talbot 933 (cited by Talbot et al. 1992 as L. hypocrita).

Porpidia tuberculosa (Sm.) Hertel \& Knoph - Occasional on rock, especially along streams and lakes, also in alpine tundra. TLC: confluentic acid (sometimes not detected).

Porpidia sp. (aff. contraponenda) - summit of Slope Mountain, overlooking Tuxedni Channel, on loose rocks on bare soil, Tønsberg 44162a. det. A. Fryday 2015 "The morphology and anatomy are a good fit for this species; it is only the chemistry that is abnormal. It should have methyl 2'-O-methylmicrophyllinate and 2'-O-methylmicrophyllinic acid." TLC: porphyrilic acid, stictic acid with satellites.

Protomicarea alpestris (Sommerf.) McCune - Katmai: ca. $1 \mathrm{~km} \mathrm{SW}$ of Malone Lake, on soil on gravelly ridge, Tønsberg 42971; camp at west end of Malone Lake, on soil, McCune 34126. Lake Clark: south end of Pickerel Lake, on gravelly soil, McCune 35257; summit of Slope Mountain, overlooking Tuxedni Channel, on soil, McCune 35383; saddle on ridge near headwaters of Johnson River, on soil, gravelly, McCune 35504. See further notes under "New Combinations" (above).

Protomicarea limosa (Ach.) Hafellner - Katmai: ridgetop W of Contact Creek, alpine tundra, Tфnsberg 42875; low rocky ridge NE of Mirror Lake, Spickerman 216, 242. Lake Clark: shoulder of basin on E side of Saddle Mountain, on soil over rock, damp shale cliffs, McCune 35436; alpine tundra, on soil, McCune 35448; small drainage on slope above NW side of Turquoise Lake, on detritus on vertical soil bank, Tфnsberg 43794; saddle on ridge near headwaters of Johnson River, on soil, Rosentreter 18874. Two collections appear to be a Pchemotype of $P$. limosa, being otherwise identical in spores and apothecial anatomy, 
including simple paraphyses. An ITS sequence obtained for one of these was nearly identical to two P+ specimens: Katmai: alluvial flats near camp on E side of Hammersly Lake, on soil, frost boils, McCune 32954; north of Mirror Lake camp, on soil and detritus, McCune 34032.

Protopannaria pezizoides (Weber) P. M. Jørg. \& S. Ekman - Common on mossy rock, wood, and soil over rock; low elevations to alpine tundra.

Protoparmelia atriseda (Fr.) R. Sant. \& V. Wirth - Lake Clark: slopes and flats above Turquoise Lake, on rock, McCune 35013.

Protoparmelia badia (Hoffm.) Hafellner - Common on rock, mostly alpine.

Protoparmelia memnonia Hafellner \& Türk - Katmai: low rocky ridge NE of Mirror Lake, on rock, McCune 32997; ridgetop W of Contact Creek, on rock, granite, McCune 34068. New to North America?

Protothelenella sphinctrinoides (Nyl.) H. Mayrh. \& Poelt - Lake Clark: summit of Slope Mountain, overlooking Tuxedni Channel, on wind-exposed, nearly vertical soil bank, Tonsberg 44175.

Pseudephebe minuscula (Nyl. ex Arnold) Brodo \& D. Hawksw. - Common on rock, less often on alpine sod, mostly at higher elevations.

Pseudephebe pubescens (L.) M. Choisy - Common on rock, mainly alpine.

Pseudocyphellaria citrina (Gyeln.) Lücking, Moncada \& S. Stenroos - Occasional on bark and wood, both hardwoods and conifers in moist low-elevation sites. Example specimens: Lake Clark: Chinitna Ranger Station, on Populus, McCune 35539 (Lücking et al. 2017); on Alnus viridis inland from beach meadow, Tonsberg 44355.

Pseudocyphellaria crocata (L.) Vainio - Numerous collections have been named this, but after revision of this group by Lücking et al. (2017), most specimens from Alaska will belong to $P$. citrina.

Pseudocyphellaria hawaiiensis H. Magn. (syn: P. perpetua McCune \& Miadlikowska) - Katmai: near Brooks Camp, S of Brooks River, along road and trail toward viewing platform, Tфnsberg 42587. Lake Clark: on Picea glauca twig, Walton 16656. See additional comments in Stehn et al. (2015, as P. perpetua) and Lücking et al. (2017).

Pseudocyphellaria holarctica McCune, Lücking \& Moncada v Katmai: NE side of Malone Lake, on Picea twig, McCune 34214 (Lücking et al. 2017).

Pseudocyphellaria mallota (Tuck.) H. Magn. - Lake Clark: near Chinitna Ranger Station, on bark, trunk of Picea sitchensis inland from beach meadow, Tønsberg 44225; only two juvenile thalli; in cyanolichen rich community with Jamesiella anastomosans, Fuscopannaria cf. ahlneri, Lichinodium sirosiphoideum, Lobaria scrobiculata, and Parmeliella parvula.

Psora decipiens (Hedwig) Hoffm. - Lake Clark: shore of Lake Clark W of Hatchet Point, Rosentreter 18792; saddle on ridge near headwaters of Johnson River, Nelson 14-611.

Psora globifera (Ach.) A. Massal. - Katmai: shoreline of Naknek Lake on peninsula NE of Brooks Camp, Tфnsberg 42715 (det. E. Timdal 2013). Lake Clark: shore of Lake Clark, stop 2, W of Hatchet Point, Rosentreter 18810.

Psora himalayana (Church. Bab.) Timdal - Lake Clark: shore of Lake Clark, W of Hatchet Point, on calcareous rock and thin soil over cliff, McCune 35320; Walton 19232.

Psora nipponica (Zahlbr.) Gotth. Schneider - Lake Clark: Portage Lake, on rock outcrop, Walton 18957; saddle on ridge near headwaters of Johnson River, on exposed cliff, alpine, Tønsberg 44284 (TLC: gyrophoric acid (major), lecanoric acid); Tanalian Falls, on mineral soil on rock outcrop, Walton 13561.

Psora rubiformis (Ach.) Hook. - Lake Clark: bay on SW side of Portage Lake, on soil over rock, McCune 35127; Rosentreter 18597; Camel's Hump on shore of Lake Clark, on soil in shallow rock crevices, Tфnsberg 44098; TLC: usnic acid, parietin (major anthraquinone), unidentified anthraquinone (trace).

Psoroma hypnorum (Vahl) Gray - Common on soil, humus, mossy rock, and dead branches; low elevations to alpine.

Psorula rufonigra (Tuck.) Gotth. Schneider - Lake Clark: shore of Lake Clark, W of Hatchet 
Point, on rock, lakeshore outcrops, McCune $35346 b$.

Pterygiopsis concordatula (Nyl.) P. M. Jørg. - Katmai: shoreline of Naknek Lake on peninsula NE of Brooks Camp, on lakeshore rock, McCune 32807 (det. Schultz). Only two apothecia were seen and only one cut, so the ID remains uncertain.

Ptychographa xylographoides Nyl. - Katmai: near Brooks Camp, S of Brooks River, along road and trail toward viewing platforms, lignicolous at edge of marsh, Tonsberg 42590. The specimen fits the descriptions of the species given by, e.g. Gilbert \& Coppins (2009), McCune (2017), except for the excipulum not being 'friable' or 'brittle' and the paraphysis tips not being dark brown. Spores: 7-10 $\times 4-5 \mu \mathrm{m}$. TLC: no substances. New to Alaska. Mixed in the collection are numerous, black sporodochia of an unidentified possibly lichenicolous, fungus; conidia brown, globose (usually) to broadly ellipsoid; spores 4-8 $84-6$ $\mu \mathrm{m}$.

Pycnothelia papillaria (Ach.) Dufour - Katmai: alluvial flats near camp on E side of Hammersly Lake, Tonsberg 42769.

Pyrenodesmia sp. - Lake Clark: NE end of Turquoise Lake, on lakeshore boulder, Tønsberg 43840 (det. Arup 2016).

Pyrenopsis furfurea (Nyl.) Th. Fr. - Lake Clark: saddle on ridge near headwaters of Johnson River, on noncalcareous stones, McCune 35512a; shoulder of basin on E side of Saddle Mountain, on shale outcrops, McCune 35428b.

Pyrenopsis haematina P. M. Jørg. \& Henssen - Lake Clark: bay on SW side of Portage Lake, on soil over rock, McCune 35155.

Pyrenopsis reducta Th. Fr. - Lake Clark: shoulder of mountain overlooking Tuxedni Bay, on rock, ephemeral snowmelt stream, McCune 35502b.

Pyrenopsis sanguinea Anzi - Occasional on rock by water and in relatively dry habitats, low elevations to alpine.

Pyrenopsis subareolata Nyl. - Lake Clark: shoulder of mountain overlooking Tuxedni Bay, on rock in ephemeral snowmelt stream, McCune 35502a.

Pyrrhospora quernea (Dickson) Körber - Lake Clark: trail to Tanalian Falls from Port Alsworth, on dry twig of Picea glauca, Tфnsberg 43727.

Ramalina almquistii Vainio - Katmai: Mt. Katmai D-6 quadrangle, 58.79814 ${ }^{\circ} \mathrm{N} 155.97318^{\circ} \mathrm{W}$, $427 \mathrm{~m}$, on rock outcrop, partial shade, Walton 13044. TLC: usnic and homosekikaic acids. This specimen was found well south of the known range of this species in North America, based on the map in Thomson (1984) and using the species concept in Joneson et al. (2004). Although otherwise robust, the specimen lacks well developed apothecia, but has numerous pycnidial warts. Unlike $R$. intermedia, which also contains the sekikaic acid complex, the thallus is strongly fistulose. The type of $R$. almquistii has divaricatic acid, but other specimens from the Kuril Islands contain the sekikaic acid complex or divaricatic acid, \pm atranorin (Joneson et al. 2004). Our specimen is apparently unusual in lacking both sekikaic acid and atranorin.

Ramalina dilacerata (Hoffm.) Hoffm. s.l. - Common on bark and wood, both hardwoods and conifers, at low elevations.

Ramalina farinacea (L.) Ach. - Common on bark and wood, both hardwoods and conifers, at low elevations.

Ramalina intermedia (Delise ex Nyl.) Nyl. - Lake Clark: Tanalian Falls SE of Port Alsworth, on rock wall, Rosentreter 18485.

Ramalina obtusata (Arnold) Bitter - Occasional, usually on Picea twigs, less often on rock. Although previously listed as a species of concern in Alaska (AKNHP 2015), Stehn et al. (2015) suggested that this should be revisited.

Ramalina pollinaria (Westr.) Ach. - Lake Clark: SW end of Pickerel Lake, on Picea twigs, Rosentreter 18646.

Ramalina roesleri (Hochst. ex Schaerer) Hue - Common on bark and wood, mainly on Picea twigs, rarely on rock, at low elevations. 
Ramalina thrausta (Ach.) Nyl. - Occasional, most often on Picea twigs, also on Betula; low elevations.

Ramboldia cinnabarina (Sommerf.) Kalb, Lumbsch \& Elix - Occasional on bark of both conifers and hardwoods.

Ramboldia subcinnabarina (Tønsberg) Kalb, Lumbsch \& Elix - Katmai: ca. $600 \mathrm{~m}$ S of W end of Malone Lake, Tфnsberg 42955. Lake Clark: shore of Chinitna Bay, ca. 3 km ENE of Chinitna Ranger Station, on Alnus viridis, Tønsberg 44393.

Rhizocarpon alpicola (Anzi) Rabenh. - Katmai: alluvial flats near camp on E side of Hammersly Lake, on rock, Muggia 073. Lake Clark: shoulder of mountain overlooking Tuxedni Bay, on rock, McCune 35493; low rocky ridge NE of Mirror Lake, McCune 32993 (TLC: psoromic acid).

Rhizocarpon anseris Lynge - Lake Clark: south end of Pickerel Lake, on stones, McCune 35262.

Rhizocarpon badioatrum (Flörke ex Sprengel) Th. Fr. - Occasional on rock, especially streamside or lakeside rock. TLC of one specimen, McCune 34178, showed barbatic acid.

Rhizocarpon caesium Fryday - Lake Clark: slopes and flats above Turquoise Lake, on rock, loose stones in alpine tundra, McCune 34963, 34969, 34970.

Rhizocarpon cinereovirens (Müll. Arg.) Vainio - Katmai: ca. 200 m N of Mirror Lake camp, on rock in alpine tundra, McCune 34050 (reduced thallus).

Rhizocarpon copelandii (Körber) Th. Fr. - Katmai: ridge above Hammersly Lake, on rock in alpine tundra, McCune 32903, 32922, Muggia 051; ridgetop W of Contact Creek, on granite in alpine tundra, McCune $34062 b$.

Rhizocarpon eupetraeoides (Nyl.) Blomb. \& Forss. - Katmai: alluvial flats near camp on E side of Hammersly Lake, on rock, Muggia 076, 078; ridgetop W of Contact Creek, on granite, Muggia 099; low rocky ridge NE of Mirror Lake, on rock, Muggia 158. Lake Clark: slopes and flats above Turquoise Lake, on rock, McCune 34947.

Rhizocarpon eupetraeum (Nyl.) Arnold - Lake Clark: shoulder of mountain overlooking Tuxedni Bay, on rock, McCune 35469.

Rhizocarpon ferax H. Magn. - Katmai: shoreline near camp on E side of Hammersly Lake, Muggia 131, 132c, 136a. Lake Clark: NW end of Turquoise Lake, on loose rock on gravel flats, McCune 35087.

Rhizocarpon geminatum Körber - Occasional on rock, including lakeshores, wet depressions, and cliff faces.

Rhizocarpon geographicum (L.) DC. s. str. - Common on rock, low elevations to more often alpine tundra.

Rhizocarpon grande (Flörke ex Flotow) Arnold - Lake Clark: Camel's Hump on shore of Lake Clark, on cliff face, McCune 35292; Tanalian Falls SE of Port Alsworth, on rock, McCune 34882 .

Rhizocarpon hensseniae Brodo - Lake Clark: shoulder of mountain overlooking Tuxedni Bay, on rock, McCune 35464.

Rhizocarpon hochstetteri (Körber) Vainio - Lake Clark: summit of Slope Mountain, overlooking Tuxedni Channel, on rock, McCune 35396a, Tønsberg 44162b (det. A. Fryday 2015).

Rhizocarpon inarense (Vainio) Vainio - Tuxedni: Chisik Island, on rock, Talbot 1032 (Talbot et al. 1992; not confirmed by us).

Rhizocarpon infernulum var. infernulum (Nyl.) Lynge - Katmai: ridge above Hammersly Lake, on rock in alpine tundra, McCune 32921.

Rhizocarpon isidiatum Tønsberg, Timdal \& McCune ined. - Katmai: NE of Mirror Lake, Tonsberg 42814a (sterile); ridgetop W of Contact Creek, on granite, Muggia 105 (det. McCune). Lake Clark: shoulder of mountain overlooking Tuxedni Bay, $60.23806^{\circ} \mathrm{N}$ $152.95673^{\circ} \mathrm{W}$, alt. $600 \mathrm{~m}$, Tonsberg 44254 (type specimen, fertile), 44164, McCune $35396 a$ (Tønsberg et al. 2018).

Rhizocarpon jemtlandicum (Malme) Malme - Katmai: ridgetop W of Contact Creek, on granite, McCune 34078; Muggia 102 (det. McCune). E. Di Meglio TLC of both specimens: stictic 
acid.

Rhizocarpon lavatum (Fr.) Hazsl. - Occasional on rock, both lakeshore and upland in alpine tundra.

Rhizocarpon lecanorinum Anders - Katmai: shoreline near camp on E side of Hammersly Lake, Muggia 137 (det. McCune; but thalli were all small).

Rhizocarpon leptolepis Anzi - Katmai: Ridgetop W of Contact Creek, on rock, granite, McCune $34064 b$, det. Timdal 2016 (Timdal TLC: confriesiic acid). Similar in appearance to $R$. bolanderi, $R$. leptolepis has spores $>4$ /ascus and smaller than in $R$. bolanderi). New to North America though reported from Greenland.

Rhizocarpon oederi (Weber) Körber - Katmai: ca. 1 km SW of Malone Lake, Tønsberg 42992, ver. E. Timdal 2016 (apothecia distinctly umbonate/gyrose; epihymenium green, K-; hypothecium dark brown; spores with halo, colorless, 3-septate, 15-19(21) $\times(3) 5-7 \mu \mathrm{m}$; TLC: nil); $300 \mathrm{~m} \mathrm{~S}$ of $\mathrm{W}$ end of Malone Lake, Muggia 111 (rusty thallus with appearance similar to Tremolecia atrata).

Rhizocarpon polycarpum (Hepp) Th. Fr. - Katmai: ridge above Hammersly Lake, on rock in alpine tundra, McCune 32929, Muggia 067b; shoreline near camp on E side of Hammersly Lake, Muggia 132a, 135 (all det. McCune). Lake Clark: bay on SW side of Portage Lake, on rock, McCune 35153; SW end of Pickerel Lake, on beach rocks, McCune 35213.

Rhizocarpon postumum (Nyl.) Arnold - Lake Clark: slopes and flats above Turquoise Lake, on loose stones, McCune 34961.

Rhizocarpon quinonum McCune, Timdal \& Bendiksby - Katmai: low rocky ridge NE of Mirror Lake, on rock, McCune 32999 (holotype); N end of ridge W of Contact Creek, on rock, McCune 34087 (McCune et al. 2016; GenBank KX079700, KX079701); gentle slopes approaching low rocky ridge NE of Mirror Lake, saxicolous in talus, Tфnsberg 42817a. TLC: stictic acid (major), satellites of stictic acid (cryptostictic and constictic acids), unknown anthraquinones Anth1 (minor) and Anth2 (major), minor unknown UV+ substances UnkUV+1 and UnkUV+2.

Rhizocarpon reductum Th. Fr. - Lake Clark: slopes and flats above Turquoise Lake, on loose stones, McCune 34962.

Rhizocarpon saanaënse Räsänen - Katmai: alluvial flats near camp on E side of Hammersly Lake, on rock, Muggia 072 (det. McCune). Lake Clark: Camel's Hump on shore of Lake Clark, on cliff face, McCune 35285, Rosentreter 18782.

Rhizocarpon sinense Zahlbr. - Katmai: shoreline of Naknek Lake on peninsula NE of Brooks Camp, on lakeshore rock, Muggia 023b (tentatively det. E. Timdal from photos; substipitate areoles; spores dark 1-septate, 35-39 × 15-16 $\mu \mathrm{m}$, cortex $\mathrm{KC}+\mathrm{red}$, medulla $\mathrm{K}-, \mathrm{P}-, \mathrm{KC}-$.) New to North America.

Rhizocarpon submodestum (Vainio) Vainio - Katmai: west end of Malone Lake, on Picea glauca, McCune 34125.

Rhizocarpon superficiale (Schaerer) Vainio - Katmai: ridge above Hammersly Lake, on rock in alpine tundra, McCune 32923; ridgetop W of Contact Creek, on granite, McCune 34062a.

Rhizocarpon umbilicatum (Ramond) Flagey - Lake Clark: Tanalian Falls SE of Port Alsworth, on rock, McCune 34910d.

Rhizoplaca chrysoleuca (Sm.) Zopf - Lake Clark: occasional on rock, especially lakeshore outcrops and boulders, low elevation to alpine; not recorded from Katmai.

Rimularia limborina Nyl. - Katmai: shoreline on north side of Mirror Lake, on boulder on beach, McCune 34016. Lake Clark: shoulder of basin on E side of Saddle Mountain, on shale outcrops, McCune 35432.

Rinodina sp. - Lake Clark: Chinitna Ranger Station on north side of Chinitna Bay, on Alnus viridis, Tфnsberg 44315 (BG). Thallus dark grey (greenish when moist), areoles scattered to $0.30 \mathrm{~mm}$ wide, surface matt, breaking into brownish consoredia and finally soralia up to 0.30 $\mathrm{mm}$ wide; soredia greenish in contrast to darker thallus; prothallus not observed. Apothecia infrequent, to $0.35 \mathrm{~mm}$ diam., constricted at base, discs dark brown, plane; thalline margin 
entire or incomplete (coronate) ca. $0.05 \mathrm{~mm}$ wide with incipient soredia on largest apothecium. Spores 8/ascus, with obvious type B development, Pachysporaria-type II, 15.5-18.0 × 8.0-9.5 $\mu \mathrm{m}(\mathrm{n}=6)$, some immature spores with attenuate apices, torus absent, walls not ornamented. Pycnidia not seen. No substances observed by TLC. The spores are very reminiscent of the eastern North American $R$. pachysperma H. Magn., but lack the tori of this species. Rinodina pachysperma may also rarely become sorediate but the lack of tori in the spores makes it unlikely that the two taxa are synonymous. Unfortunately, the specimen is too sparse to allow a formal description of this taxon. It is accompanied by a poorly developed specimen of $R$. pallidescens, "Dendriscocaulon" sp., Fuscopannaria ahlneri (richly fertile), and Parmeliella parvula (the two latter specimens, conf. P. M. Jørgensen 2018).

Rinodina archaea (Ach.) Arnold - Lake Clark: campsite at NW end of Turquoise Lake, on wood, McCune 35067; on caribou jawbone, in alpine tundra, Tфnsberg 43800; shore of Chinitna Bay, ca. $4 \mathrm{~km}$ ENE of Chinitna Ranger Station, on driftwood, Tonsberg 44380. Tuxedni: Chisik Island; 0.5 miles north of Cannery, on Alnus crispa, Talbot 303 (ver. Sheard 2016). The Lake Clark records are the westernmost in North America. They are also the most northerly, except for one locality in the Mackenzie Delta (Scotter 8328C, H recently verified).

Rinodina badiexcipula Sheard - Katmai: NE side of Malone Lake, on porous wood, Tønsberg 43049. New to Alaska and a major disjunction from its usual range in California and southern Oregon (Sheard 2010), similar to that of $R$. oregana (Sheard et al. (2014); occurring with $R$. cinereovirens, $R$. pallidescens and $R$. trevisanii.

Rinodina buckii Sheard - Katmai: near Brooks Camp, Tønsberg 42571, 42695. Lake Clark: Chinitna Ranger Station, on Alnus viridis inland from beach meadow, Tonsberg 44305, 44343,44345 . These young collections have soredia first forming in the center of the areoles thereby distinguishing the taxon from $R$. willeyi. Recently published as new to western North America (Sheard et al. 2014).

Rinodina cinereovirens (Vainio) Vainio - Lake Clark: occasional on wood, mossy wood, conks, roots, Betula bark, and Alnus; Tuxedni: Chisik Island, Alnus thicket, eastern coast of island, on Alnus crispa, Talbot 88063-Y-4 (WIS, previously reported as $R$. septentrionalis by Talbot et al. 1992). Distinguished from $R$. turfacea by the spores which are frequently 4/ascus, typically shorter in median size and more broadly ellipsoid with blunt apices, $(23.0-30.0 \times$ 13.0-14.5 $\mu \mathrm{m}, \mathrm{n}=20$ ), and by its corticolous substrate. The apothecia also tend to be smaller, with plane discs (never concave) that may become convex. This species was not separated from $R$. turfacea by Sheard (2010) and is certainly much less frequent with a boreal rather than oroarctic distribution. First recorded for North America by Sheard et al. (2017).

Rinodina cinnamomea (Th. Fr.) Räsänen - Lake Clark: saddle on ridge near headwaters of Johnson River, on tundra sod, McCune $35517 \mathrm{~b}$; slopes and flats above Turquoise Lake, on soil in tundra, Tonsberg 43741. Previously regarded as a chemical variety (medulla containing skyrin) of $R$. mniaraea by Mayrhofer \& Moberg (2002) but not separated from that species by Sheard (2010). Molecular studies by Resl et al. (2016) indicate that all three chemotypes of $R$. mniaraea deserve species status.

Rinodina colobina (Ach.) Th. Fr. - Lake Clark: shore of Lake Clark, W of Hatchet Point, on trunk of Populus, Tonsberg 44118. This miniscule specimen has only two apothecia but they are unmistakable because of the bluish grey thallus and $\mathrm{K}+$ violet epihymenium. The specimen was too immature to develop the typical dark consoredia. New to Alaska.

Rinodina conradii Körber - Occasional on moss, bark, conk, and soil, low elevation to alpine tundra. New to southern Alaska.

Rinodina disjuncta Sheard \& Tønsberg Lake Clark: Chinitna Ranger Station, on Alnus, McCune 35554, Tønsberg 44200. Sterile, distinguished by the dark greenish to brownish, convex areoles erupting into consoredia, sphaerophorin present. When fertile, its spores are large and belong to the Physcia-Physconia-type. In Alaska previously recorded from the south, central parts of the state (Sheard 2010). 
Rinodina efflorescens Malme - Occasional on Alnus at low elevations. Characterized by discrete, yellowish soralia due to the presence of secalonic acid, also with pannarin. In Alaska previously recorded from southern and central parts (Sheard 2010).

Rinodina freyi H. Magn. - Lake Clark: low ridge above inlet stream to Pickerel Lake, on twig, Picea, McCune 35266. Lake Clark: near SW end of Pickerel Lake, on Picea twig, McCune $35217 b$; shore of Lake Clark, stop 2, W of Hatchet Point, on decorticate Picea glauca log, Tфnsberg 44131. Spores not separable from $R$. septentrionalis but is distinguished by its plane thallus occupying relatively mesic microhabitats around leaf scars, etc. In Alaska previously recorded from southern and central parts (Sheard 2010).

Rinodina griseosoralifera Coppins - Katmai: shore of Naknek Lake, bay just N of Brooks Camp, below crumbling outcrops, Tønsberg 42730, 42748. Lake Clark: shore of Lake Clark, W of Hatchet Point, on trunk of Populus, Tønsberg 44111. In Alaska previously known from Kodiak Island and southern parts (Sheard 2010).

Rinodina incurva Sheard \& J. Walton - Katmai: Katmai Bay Bear Cam, $58.0048^{\circ} \mathrm{N}, 155.0442^{\circ} \mathrm{W}$, $18 \mathrm{~m}$, on Populus balsamifera bark on bole, Walton 18600 (holotype: ALA; isotypes: BG, OSC; known only from this type locality; see Sheard 2018).

Rinodina laevigata (Ach.) Malme - Occasional on Alnus at low elevations. In Alaska the species is characterized by dispersed apothecia with disks tending to become convex. The deep amphithecium cortex, 40-60 $\mu \mathrm{m}$, of intricate hyphae is diagnostic, coupled with the lack of secondary substances. It is often accompanied by other Rinodina species. In Alaska previously known from Kodiak Island and southern parts (Sheard 2010).

Rinodina metaboliza Vainio - Katmai: near Brooks Camp, S of Brooks River, along road and trail toward viewing point, on twigs of Picea glauca in mixed Picea/Betula neoalaskana forest near lakeshore, Tonsberg 42566. Characterized by the Dirinaria-type spores and the lack of secondary substances. In Alaska previously recorded from the south-central region (Sheard 2010).

Rinodina milvina (Wahlenb.) Th. Fr. - Lake Clark: NW end of Turquoise Lake, on lakeshore rock, McCune 35080. This is a well-developed specimen with apothecia developing to a larger size than typical, with some discs becoming convex. These characters suggest $R$. arnoldii $\mathrm{H}$. Mayrhofer \& Poelt but the spores are of the typical Milvina-type in both shape and structure (Sheard 2010) and show no tendency towards the Pachysporaria-type typical of $R$. arnoldii (Mayrhofer \& Sheard 1988). New to Alaska and an important range extension, the species not having been recorded previously north of the southern Canada-U.S. boundary (Sheard 2010). It is found in extreme northern Norway (west and east Finmark, Mayrhofer \& Moberg 2002) but is absent from Greenland and cannot be regarded as a true Arctic species. Preliminary DNA analysis by Arup indicates that the specimen is not identical to the species in Europe and that it also differs slightly genetically from material collected in Montana. To evaluate the status of the specimen from Alaska more material is needed.

Rinodina mniaraea (Ach.) Körber - Lake Clark: slopes and flats above Turquoise Lake, on soil in tundra, Tønsberg 43740. This species is frequent in Alaska but not as common as R. turfacea in the High Arctic. It is also more abundant in the southern Rockies and at lower elevations around treeline.

Rinodina oleae Bagl. Lake Clark: near SW end of Pickerel Lake, on dead Alnus viridis in steep slope above, Tonsberg 44016. The identification is tentative, particularly as it has not previously been recorded from Alaska or anywhere in the Pacific Northwest of North America.

Rinodina olivaceobrunnea C. W. Dodge \& Baker Lake Clark: bay on SW side of Portage Lake, on moss on lakeshore rock, Tфnsberg 43957 (det. H. Mayrhofer); saddle on ridge near headwaters of Johnson River, on tundra sod, McCune 35517a; slopes and flats above Turquoise Lake, on Salix wood and organic matter, Rosentreter 18537, 18547. It is surprising that this species is not more frequent given that it often occurs with $R$. turfacea elsewhere in the Arctic. 
Rinodina oregana $\mathrm{H}$. Magn. - Katmai: near shore of Naknek Lake, $\mathrm{N}$ of Brooks Camp, on trunk of Populus balsamifera or trichocarpa, McCune 32889, Tфnsberg 42656. See Sheard et al. (2014) for additional comments.

Rinodina pallidescens Sheard \& Tønsberg - Fairly common on Alnus, Populus, and Salix (Sheard et al. 2014). This species is hardly distinguishable from $R$. laevigata by external habit or by spore size. However, the Physcia-type spores of $R$. pallidescens differ from those of $R$. laevigata in frequently having only 4 spores/ascus, a very rare occurrence in the latter species. Rinodina pallidescens is best distinguished from $R$. laevigata by the presence of the secondary compound gracilenta unknown 1 (Tønsberg 1992) and the lack of a well-developed apothecial cortex (not exceeding $20 \mu \mathrm{m}$ ).

Rinodina roscida (Sommerf.) Arnold - Lake Clark: NW end of Turquoise Lake, on Peltigera lepidophora on root wad, McCune 35047b. Most typically a high Arctic or high mountain species on calcareous substrates. New to southern Alaska.

Rinodina septentrionalis Malme - Common on bark of both hardwoods and conifers, low elevations to alpine shrubs. Although difficult to distinguish from $R$. freyi when immature, the scattered apothecia and convex areoles are diagnostic; frequent throughout Alaska (Sheard 2010).

Rinodina sibirica H. Magn. - Occasional on Alnus, Picea, and Salix at low elevations. The specimens have uncharacteristically small apothecia and possess large spores. The apothecia at ca. $0.4 \mathrm{~mm}$ diam. are smaller than recorded by Sheard (2010) and not wide enough to become stipitate although some become convex or half globose as previously recorded. The spores may be only 4/ascus, a fact that has not previously been noted. Those of the present specimens mostly belong to the Physcia-type although some may become Physconia-type. At $(20.5) 22.0-24.0(25.5) \times(9.0) 10.0-11.0(12.0) \mu \mathrm{m}, 1 / \mathrm{w}$ ratio $(1.9) 2.0-2.3(2.4) \quad(\mathrm{n}=60)$, the spores tend to be longer and therefore more elongate than typical. They are heavily pigmented and with prominent tori as usual. These anomalies may be due to the less continental conditions of the region than previously examined material (Sheard 2010). One specimen, Tфnsberg 43695, has zeorin, a substance not previously been recorded for this species. The species has not previously been recorded from south-central or southern Alaska (Sheard 2010). The species may have a Beringian distribution as it does not occur east of Hudson Bay or in Greenland.

Rinodina subpariata (Nyl.) Zahlbr. (Syn. R. degeliana Coppins) - Common on Alnus, less so on Betula and Picea, at low elevations, mainly at Lake Clark. Characterized by light grey thallus and whitish soredia originating marginally, often spreading over surface of areoles, and the presence of abundant atranorin. Only two poorly fertile specimens found (Tonsberg 42694, 44344) were found, both with overmature spores. Molecular studies (Resl et al. 2016) have shown $R$. degeliana to be synonymous with the fertile, non-sorediate $R$. subpariata previously thought to be endemic to Japan.

Rinodina trevisanii (Nyl.) Zahlbr. - Katmai: NE side of Malone Lake, on porous wood, Tønsberg 43049.

Rinodina turfacea (Wahlenb.) Körber var. turfacea - Common on moss and other lichens, bark, moss over rock, soil, humus, and tundra sod; low elevations to alpine. Typically very common on decaying vegetation on tundra but not previously recorded from south-central or southern Alaska (Sheard 2010).

Rinodina willeyi Sheard \& Giralt - Lake Clark: low ridge above inlet stream to Pickerel Lake, on trunk of Betula, Tфnsberg 44057; Chinitna Ranger Station, on Alnus viridis inland from beach meadow, Thnsberg 44308; SW end of Pickerel Lake, on dead Alnus viridis on steep slope, Tonsberg 44015, 44016. Specimens have soredia that first appear on the areole margins thus distinguishing them from $R$. buckii. Young areoles are somewhat reminiscent of $R$. subpariata but the thallus and soredia are a darker grey, and contain pannarin rather than atranorin. New to Alaska, these are the first records from western North America (Sheard 2010). 
Aff. Ropalospora hibernica (P. James \& Poelt) Tønsberg - Katmai: Ridgetop W of Contact Creek, saxicolous in shaded cavity under boulder, Tønsberg 42871 (sterile; GenBank blast for ITS: Umbilicaria. TLC: 2 fatty acids (one visible in UV light on undeveloped plates), lacking gyrophoric acid. Thallus covering most of the flat surface of two rock pieces, up to $6 \mathrm{~cm}$ diam., pale creamy white or pale(!) brownish, at first forming \pm flat, rimose-cracked patches to $1(-2) \mathrm{mm}$ diam., later becoming \pm continuous and obscuring the prothallus, with distinctly convex to tuberculate areoles, sorediate; soralia mostly discrete and well delimited, surface flat to slightly concave, pale creamy white; soredia mostly farinose $(<30 \mu \mathrm{m})$, some external soredia brownish in a few soralia; prothallus similar to that of typical Fuscidea, brown, between young thallus patches and along the thallus edge, at the outermost fringe of bundles of hyphae; apothecia and pycnidia not seen; photobiont green, coccoid.

Ropalospora lugubris (Sommerf.) Poelt - Lake Clark: summit of Slope Mountain, overlooking Tuxedni Channel, on rock, McCune 35395; summit of Slope Mountain, overlooking Tuxedni Channel, on rock, McCune 35396b, 35397.

Rostania ceranisca (Nyl.) Otálora, P.M. Jørg. \& Wedin - Katmai: 59.1182º $155.08567^{\circ} \mathrm{W}, 500$ $\mathrm{m}$, on moss over ground, Walton 13331. Lake Clark: bay on SW side of Portage Lake, on soil and moss over rock, McCune 35154.

Rostania occultata var. populina (Th. Fr.) Perlmutter \& Rivas Plata - Katmai: near National Park Service bunkhouse in King Salmon, on bark, Salix, McCune 32695; shore of Naknek Lake, bay just N of Brooks Camp, below crumbling outcrops, on Salix, McCune 34116a. See also comments in Stehn et al. (2015).

Rusavskia elegans (Link) S. Y. Kondr. \& Kärnefelt - Common on rock, low elevations to alpine. Two distinct but as yet unnamed species are lumped under this name, separable by both morphology and DNA sequences. Both are common in this area and they frequently co-occur.

Rusavskia sorediata (Vainio) S.Y. Kondr. \& Kärnefelt - Katmai: shoreline of Naknek Lake on peninsula NE of Brooks Camp, on rock, lakeside cliff, McCune 32810, Muggia 017. Lake Clark: shore of Lake Clark, W of Hatchet Point, on $\mathrm{HCl}+$ rock, McCune 35309; Tanalian Falls SE of Port Alsworth, on rock, McCune 34906.

Sagedia mastrucata (Wahlenb.) A. Nordin, S. Savić \& Tibell - Katmai: ca. $850 \mathrm{~m} \mathrm{~S}$ of W end of Malone Lake, Tønsberg 42969b. TLC: norstictic acid (major).

Sagiolechia rhexoblephara (Nyl.) Zahlbr. - Lake Clark: summit of Slope Mountain, overlooking Tuxedni Channel, on soil, McCune 35382. Tuxedni: Chisik Island, Talbot 754 (Talbot et al. 1992).

Santessoniella sp. - Lake Clark: Tanalian Falls SE of Port Alsworth, on rock, McCune 34910a. Dwarf-fruticose, branchlets $50 \mu \mathrm{m}$ in diameter, small-celled cortex, containing Nostoc?

Santessoniella arctophila (Th. Fr.) Henssen - Katmai: shoreline of Naknek Lake on peninsula NE of Brooks Camp, on rock, mossy, McCune 32806c.

Schaereria corticola Muhr \& Tønsberg - Occasional on bark of Alnus and Salix at low elevations.

Schaereria dolodes (Nyl. ex Hasse) Schmull \& T. Sprib. - Katmai: ca. $1 \mathrm{~km} \mathrm{SW}$ of Malone Lake, on Andreaea over rock, McCune 34179. Normally epiphytic in the lower 48 states, this species was not seen as an epiphyte in this area.

Schaereria endocyanea (Stirton) Hertel \& Gotth. Schneider - Katmai: low rocky ridge NE of Mirror Lake, on rock, Muggia 167 (det. McCune, apothecia soon sessile, not aspicilioid; epithecium with dense violet granules).

Schaereria fuscocinerea (Nyl.) Clauzade \& Cl. Roux - Katmai: Shoreline on east side of Hammersly Lake, on shoreline cobbles, McCune 32977. Lake Clark: shoulder of mountain overlooking Tuxedni Bay, on rock, McCune 35471; slopes and flats above Turquoise Lake, on rock in tundra, McCune 34943b; summit of Slope Mountain, overlooking Tuxedni Channel, on argillite in tundra, McCune $35421 b$.

Sclerophora coniophaea (Norman) J. Mattsson \& Middelb. - Lake Clark: $200 \mathrm{~m}$ west of west end of Portage Lake, on base of Picea glauca, Nelson 14-560a; Chinitna Ranger Station, on Picea, Nelson 14-131. 
Scoliciosporum chlorococcum (Stenh.) Vězda - Katmai: ca. $800 \mathrm{~m} \mathrm{~S}$ of W end of Malone Lake, on Picea, McCune 34172; near Brooks Camp, S of Brooks River, lignicolous on twig of Picea, Tфnsberg $42593 b$ (epithecium deep blue-green, N+ purple).

Scoliciosporum umbrinum (Ach.) Arnold - Occasional on bark of both hardwoods and conifers, rarely on rock, at low elevations.

Scytinium cellulosum (P. M. Jørg.) Otálora, P.M. Jørg. \& Wedin - Occasional on bark of Populus at low elevations.

Scytinium gelatinosum (With.) Otálora, P.M. Jørg. \& Wedin - Katmai: shoreline of Naknek Lake on peninsula NE of Brooks Camp, on moss over lakeside cliff, McCune 32815; on beach rock, Nelson 13-231. Lake Clark: $60.4804^{\circ} \mathrm{N}, 154.0819^{\circ} \mathrm{W}, 1003 \mathrm{~m}$, on mineral soil, Walton $16459 a$.

Scytinium intermedium (Arn.) Otálora, P.M. Jørg. \& Wedin - Occasional on moss, mossy rock, and soil (dets. by Schultz and Rosentreter).

Scytinium lichenoides (L.) Otálora, P.M. Jørg. \& Wedin - Occasional on soil or moss over rock at low elevations.

Scytinium pulvinatum (Hoffmann) Otalora - Lake Clark: shore of Lake Clark ca. $30 \mathrm{~km}$ NE of Port Alsworth, W of Hatchet Point, on moss over rock, McCune 35333 (det. Schultz).

Scytinium rivale (Tuck.) Otálora, P.M. Jørg. \& Wedin - Katmai: low rocky ridge NE of Mirror Lake, on rock in seep, Nelson 13-187.

Scytinium subtile (Schrad.) Otálora, P. M. Jørg. \& Wedin - Katmai: shoreline of Naknek Lake on peninsula NE of Brooks Camp, on damp soil on cliff, McCune 32800 (det. Schultz 2014).

Scytinium teretiusculum (Wallr.) Otálora, P.M. Jørg. \& Wedin - Occasional on bark of Populus balsamifera at low elevations.

Siphula ceratites (Wahlenb.) Fr. - Occasional on mineral soil, gravel, soil over rock, and humus, usually at higher elevations.

Solorina bispora Nyl. - Lake Clark: $60.57^{\circ} \mathrm{N}, 154.188^{\circ} \mathrm{W}, 874 \mathrm{~m}$, on mineral soil, Walton 15943.

Solorina crocea (L.) Ach. - Common on soil, mostly subalpine to alpine.

Solorina saccata (L.) Ach. - Occasional on mineral soil, rock crevices, and moss over rock.

Sphaerophorus fragilis (L.) Pers. - Occasional on rock, moss, and alpine sod in tundra.

Sphaerophorus globosus (Hudson) Vainio - Common on humus, soil, and alpine sod in tundra

Sphaerophorus tuckermanii Räsänen - Lake Clark: Chinitna Ranger Station, on Picea, McCune 35575, 35583, Walton 15630, 19224.

Sphaerophorus venerabilis Wedin, Hognabba \& Goward - Katmai: Katmai Bay Bear Cam, $58.0048^{\circ} \mathrm{N}, 155.0442^{\circ} \mathrm{W}, 18 \mathrm{~m}$, partial shade, mesic, Betula neoalaskana trunk, Walton 18645. Lake Clark: Chinitna Ranger Station, on Picea, McCune 35582, Rosentreter 18912, Tonsberg 44229, Walton 19225.

Sphinctrina turbinata (Pers.: Fr.) De Not. - Lake Clark: bay on SW side of Portage Lake, on soil and moss over rock, McCune 35130b; on wood of dry branch of Picea glauca on lakeshore, Tønsberg 43946.

Spilonema americanum (Henssen \& Tønsberg) T. Sprib., Muggia \& Tønsberg - Katmai: near shore of Naknek Lake, $\mathrm{N}$ of Brooks Camp, Tønsberg 42654.

Spilonema revertens Nyl. - Lake Clark: saddle on ridge near headwaters of Johnson River, on tundra sod, McCune 35516b; shore of Lake Clark, W of Hatchet Point, on moss, Rosentreter 18795; shore of Lake Clark, stop 2, W of Hatchet Point, on rock, lakeshore outcrops, McCune $35346 a$.

Sporastatia polyspora (Nyl.) Grummann - Common on noncalcareous rock in alpine.

Sporodictyon cruentum (Körber) Körber - Katmai: shoreline near camp on N side of Mirror Lake, on boulder on beach, McCune 34015 .

Sporodictyon schaererianum A. Massal. - Katmai: ca. 600 m N of Mirror Lake camp, Tønsberg 42859 (det. A. Botnen 2014).

Staurothele arctica Lynge - Lake Clark: shoulder of mountain overlooking Tuxedni Bay, on rock, ephemeral snowmelt stream, McCune 35501; summit of Slope Mountain, overlooking 
Tuxedni Channel, on rock in seepage track, McCune 35418,35427a, 35390.

Staurothele areolata (Ach.) Lettau - Katmai: shoreline of Naknek Lake on peninsula NE of Brooks Camp, on rock, lakeshore, McCune 32826a, 32828a, Muggia 031. Lake Clark: bay on SW side of Portage Lake, on rock, wetted lakeshore boulder, McCune 35137.

Staurothele clopima (Wahlenb.) Th. Fr. - Occasional on rock in streams, stones in spring, ironstained lakeshore rock, lakeshore cobbles, McCune 32970.

Staurothele drummondii (Tuck.) Tuck. - Lake Clark: shore of Lake Clark, stop 2, W of Hatchet Point, on rock, wetted lakeshore, McCune $35358 b$.

Staurothele fissa (Taylor) Zwackh - Katmai: shoreline of Naknek Lake on peninsula NE of Brooks Camp, on lakeshore rock, McCune 32824b. Lake Clark: NW end of Turquoise Lake, on rock, lakeshore, McCune 35059.

Staurothele frustulenta Vainio - Lake Clark: campsite at NW end of Turquoise Lake, on lakeshore rock, McCune 35075. Lake Clark: shore of Lake Clark, W of Hatchet Point, on wetted lakeshore marble, McCune 35337.

Stereocaulon alpinum Laurer ex Funck - Common on soil, humus, and moss, low elevations to alpine tundra.

Stereocaulon apocalypticum Nyl. - Occasional on rock and soil over rock; not recorded from Katmai. Lake Clark: $60.621^{\circ} \mathrm{N}, 154.018^{\circ} \mathrm{W}, 978 \mathrm{~m}$, rubble slope in full sun, Walton 15604 , $15605 ; 60.818^{\circ} \mathrm{N}, 153.985^{\circ} \mathrm{W}, 978 \mathrm{~m}$, Walton 13733; slopes and flats above Turquoise Lake, McCune 34952, 34956, 34992, Tфnsberg 43738, 43746, 43751.

Stereocaulon arcticum Lynge - Katmai: ca. $200 \mathrm{~m} \mathrm{~N}$ of Mirror Lake camp, on soil, bottom of frost boil, McCune 34043 (TLC: atranorin + stictic acid; containing Nostoc). Perhaps just a Nostoc-containing morph of $S$. vesuvianum, ITS sequences revealed no consistent difference from North American S. vesuvianum (DNA sequence results to be reported in more detail elsewhere).

Stereocaulon areolatum McCune, E. Di Meglio \& Tonsberg ined. - Lake Clark: shoulder of mountain overlooking Tuxedni Bay, on rock, ephemeral snowmelt stream, McCune 35498; on metal-rich rock, McCune 35486; on pebbles, Tønsberg 44269a,b, 44271. TLC (all specimens): atranorin, lobaric acid.

Stereocaulon arenarium (Savicz) Lamb - Lake Clark: summit of Slope Mountain, overlooking Tuxedni Channel, on rock, McCune 35366; shoulder of basin on E side of Saddle Mountain, on soil, McCune 35447; saddle on ridge near headwaters of Johnson River, on gravelly soil, McCune 35503; shoulder of mountain overlooking Tuxedni Bay, on soil, Rosentreter 18865; tableland near Turquoise Lake, $1252 \mathrm{~m}$, on mineral soil, Walton 13769; on humus, $1187 \mathrm{~m}$, Walton AEM_2010_111g. TLC (all specimens): atranorin, porphyrilic acid. Photobiont (all specimens): Nostoc.

Stereocaulon botryosum Ach. - Occasional, usually directly attached to rock, low elevations to alpine tundra. TLC (all specimens): atranorin, porphyrilic acid, rarely with atranorin only. Photobiont: Nostoc. Tuxedni: one of three specimens cited by Talbot et al. (1992) was located in WIS and found to be $S$. alpinum (TLC: atranorin, lobaric acid)

Stereocaulon condensatum Hoffm. - Occasional on soil, mainly alpine. Katmai: ca. $850 \mathrm{~m} \mathrm{~S}$ of W end of Malone Lake, McCune 34163. Lake Clark: low ridge above inlet stream to Pickerel Lake, McCune 35268; near outlet of Turquoise Lake, McCune 35113; near SW end of Pickerel Lake, Rosentreter 18676; saddle on ridge near headwaters of Johnson River, Walton 19299, 19303; shoulder of mountain overlooking Tuxedni Bay, Rosentreter 18867. TLC (most specimens): atranorin, lobaric acid. Photobiont: Stigonema.

Stereocaulon glareosum (Savicz) H. Magn. - Katmai: (Schindler 1990). Lake Clark: near campsite at NW end of Turquoise Lake, on soil, gravelly, McCune 35062, Tфnsberg 43732; near SW end of Pickerel Lake, on sandy bank just inland from lakeshore beach, Tønsberg 44065; summit of Slope Mountain, overlooking Tuxedni Channel, on soil in alpine, ericaceous heath, Tønsberg 44157; west side of Turquoise Lake, on soil, Tønsberg 43881. Tuxedni: Chisik Island, Talbot 1218 (TLC: atranorin only; original ID was $S$. rivulorum in Talbot et al. 1992). 
Stereocaulon groenlandicum (E. Dahl) Lamb - Katmai: ridge above Hammersly Lake, on soil, solifluction lobe in alpine, with the microliverwort Anthelia, McCune 32948; $3 \mathrm{~km}$ E of Hammersly Lake, alpine tundra, on rock, Walton 16363. TLC: atranorin, perlatolic and miriquidic acids, trace anziaic acid; medulla $\mathrm{KC}-$, S+R (Alphandary \& McCune 2013).

Stereocaulon hypothallinum McCune, E. Di Meglio \& Tonsberg ined. - Katmai: N end of ridge W of Contact Creek, Tфnsberg 42884 (fertile). TLC: stictic acid. So far this is the only known locality for this species (McCune et al, unpublished).

Stereocaulon intermedium (Savicz) H. Magn. - Tuxedni: Chisik Island; 0.5 miles north of Cannery, Talbot 438 (WIS; reported as S. saviczii by Talbot et al. 1992).

Stereocaulon klondikense T. Sprib. - Katmai: low rocky ridge NE of Mirror Lake, on rock, McCune 32995, 32996. TLC: atranorin, lobaric acid. Photobiont: Stigonema.

Stereocaulon paschale (L.) Hoffm. - Common on soil, humus, moss, and those substrates over rock, low elevations to alpine tundra.

Stereocaulon plicatile (Leighton) Fryday \& Coppins - Katmai: ca. $1 \mathrm{~km} \mathrm{SW}$ of Malone Lake, Tфnsberg 42994 (sterile; primitive cephalodia present; ITS sequence; TLC: stictic acid and associates; McCune et al. unpublished manuscript).

Stereocaulon rivulorum H. Magn. - Katmai: $5.25 \mathrm{~km}$ NE of Mirror Lake, alpine fellfield, on rock, Walton 16388. Lake Clark: tableland $\mathrm{N}$ of Turquoise Lake, alpine tundra, on soil, Walton 13699. TLC: atranorin, perlatolic and anziaic acids. Photobiont: Nostoc. Some specimens assigned to $S$. alpinum may belong to the lobaric acid chemotype of $S$. rivulorum, the two seeming to intergrade in morphology.

$\times$ Stereocaulon saxatile H. Magn. - Tuxedni: Talbot et al. (1992), misidentifications of S. alpinum.

Stereocaulon spathuliferum Vainio - Occasional on rock, especially cliff faces. Katmai: NPS site 2010_03_049, Miller AEM_2010_167h; low rocky ridge NE of Mirror Lake, on rock, McCune 34001; ridgetop W of Contact Creek, McCune 34084, 34091. Tuxedni: Chisik Island, Talbot 856 (misidentified as $S$. condensatum in Talbot et al. 1992). TLC (all specimens): atranorin, stictic \pm norstictic acid. The material is heterogeneous in morphology and DNA sequences. The following specimens appear to correspond to Lamb's (1977) use of S. spathuliferum f. globiferum (H. Magn.) Lamb - Katmai: ridge above Hammersly Lake, on rock, McCune 32939b; ridgetop W of Contact Creek, on rock, McCune 34080. Lake Clark: summit of Slope Mountain, on rock, Tønsberg 44173; on soil, Walton 19298.

Stereocaulon subcoralloides (Nyl.) Nyl. - Lake Clark: $60.8179^{\circ} \mathrm{N}, 153.9929^{\circ} \mathrm{W}$, on mineral soil in dwarf shrub tundra, Walton 13752; shoulder of mountain overlooking Tuxedni Bay, on rock, McCune 35473; slopes and flats above Turquoise Lake, on rock, McCune 34942, Rosentreter 18533. TLC: atranorin, lobaric acid. Photobiont: Stigonema. Not recorded from Katmai; normally occurring directly on rock but sometimes on gravelly soil.

Stereocaulon symphycheilum Lamb - Katmai: ridgetop W of Contact Creek, on soil in rock crevice, granite, McCune 34081a. Lake Clark: slopes and flats above Turquoise Lake, on rock, McCune 34981, McCune 35016. TLC: atranorin, lobaric acid. Photobiont: Stigonema.

Stereocaulon tomentosum Fr. - Common on humus, soil, and forest floor, mainly at low elevations.

Stereocaulon vesuvianum Pers. - Common on rock, soil, moss, and humus, low elevations to alpine. TLC: atranorin, stictic acid. Photobiont: Stigonema. The thallus is extremely variable in morphology, even within a locale, ranging from very dense cushions to openly branched forms. Either of those can bear soredia, though the soredia seem more frequent on openly branched individuals.

Sticta arctica Degel. - Lake Clark: occasional on moss, humus, or soil over rock. Not recorded from Katmai.

Sticta fuliginosa (Hoffm.) Ach. - Locally common in low elevation moist forest on the coast, on various woody substrates Lake Clark: on Picea glauca twig, Walton 15628; Chinitna Ranger Station, McCune 35550, 35574; Rosentreter 18891; Tønsberg 44228, 44235, 44294; Walton 19207. 
Sticta limbata (Sm.) Ach. - Lake Clark: Camel's Hump on shore of Lake Clark, on lakeshore rock $5 \mathrm{~m}$ above lake, Tønsberg 44073; Chinitna Ranger Station, on Alnus, Walton 19206; Lake Clark B-3, partial shade, mesic, Picea glauca branch, Walton 18976; Lake Clark: Telaquana Lake, partial shade, mesic, Picea glauca branch, Walton 18870.

Sticta weigelii (Ach.) Vainio s.l. - Lake Clark: Chinitna Ranger Station, on Picea twig, McCune 35581 .

Strangospora microhaema (Norman) R. Anderson - Katmai: near shore of Naknek Lake, N of Brooks Camp, Tфnsberg 42663; det. Z. Palice 2014.

Synalissa ramulosa (Bernh.) Körber - Lake Clark: shore of Lake Clark, W of Hatchet Point, on $\mathrm{HCl}+$ rock, McCune 35307d, Rosentreter 18797c.

Tephromela atra (Hudson) Hafellner - Occasional on rock, low elevation to alpine.

Tetramelas chloroleucus (Körber) A. Nordin Lake Clark: near SW end of Pickerel Lake, on Populus tremuloides bark, Rosentreter 18650.

Tetramelas insignis (Nägeli) Kalb - Lake Clark: bay on SW side of Portage Lake, on soil over rock, McCune 35160; near outlet of Turquoise Lake, on tundra sod, McCune 35115; saddle on ridge near headwaters of Johnson River, on tundra sod, McCune $35518 b$.

Tetramelas triphragmioides (Anzi) A. Nordin \& Tibell - Katmai: Headwaters Creek, SW of Malone Lake, Tønsberg 43007 (spores 3-septate to muriform, thallus containing arthothelin; mixed with Rinodina). Lake Clark: bay on SW side of Portage Lake, on Picea twig, McCune 35121b; SW end of Pickerel Lake, on hardwood bark, McCune 35215; near Tanalian Falls, on bark of dead Salix, Tønsberg 43684 (spores becoming 3-septate, too small for TLC, but squash of thallus $\mathrm{C}+$ orange).

Thamnolia subuliformis (Ehrh.) Culb. - Common on soil, humus, moss, and alpine sod.

Thamnolia vermicularis (Sw.) Ach. ex Schaerer - Common on soil, humus, moss, and alpine sod. The traditional distinction between $T$. subuliformis and $T$. vermicularis was not supported by a global analysis by Onut-Brannstrom et al. (2017), but they demonstrated that two clades do exist; see also Leavitt et al. (2016).

Thelenella modesta (Nyl.) Nyl. - Katmai: near shore of Naknek Lake, N of Brooks Camp, Tфnsberg 42657, det. A. Botnen 2014.

Thelidium minutulum Körber - Lake Clark: shoulder of basin on E side of Saddle Mountain, on rock in rivulet, $\mathrm{McC}$ Cune $35455 \mathrm{a}$.

Thelignya lignyota (Wahlenb.) P. M. Jørg. \& Henssen - Lake Clark: shore of Chinitna Bay, ca. 4 $\mathrm{km}$ ENE of Chinitna Ranger Station, on rock, sandstone boulder on shoreline, McCune 35640a; shore of Lake Clark, stop 2, W of Hatchet Point, on rock, wetted lakeshore, McCune $35358 a$.

Thelocarpon epibolum Nyl. - Lake Clark: near campsite at NW end of Turquoise Lake, on soil bank facing lake, Tonsberg 43822.

Tingiopsidium elaeinum (Wahlenb. ex Ach.) Hafellner \& T. Sprib. - Katmai: Shoreline near camp on north side of Mirror Lake, on boulder on beach, McCune 34022. Lake Clark: shoulder of basin on E side of Saddle Mountain, on shale outcrops, McCune 35428a.

Tingiopsidium isidiatum (Degel.) Hafellner \& T. Sprib. - Katmai: ca. $200 \mathrm{~m} \mathrm{~N}$ of Mirror Lake camp, on streamside noncalcareous boulder, McCune 34028; shoreline near camp on north side of Mirror Lake, Muggia 188, 189. Lake Clark: near outlet of Turquoise Lake, on lakeshore boulder, McCune 35103.

Toensbergia leucococca (R. Sant.) Bendiksby \& Timdal - Common on various woody plants, low elevations to alpine.

Toninia opuntioides (Vill.) Timdal - Lake Clark: shore of Lake Clark, W of Hatchet Point, on soil over rock, McCune 35315.

Toninia sedifolia (Scop.) Timdal - Katmai: partial shade, mesic, soil over sedimentary rock ledge, Walton 18564. Lake Clark: Camel's Hump on shore of Lake Clark, on soil, Rosentreter $18771,18773$.

Toninia squalescens (Nyl.) Th. Fr. - Lake Clark: small drainage on slope above NW side of 
Turquoise Lake, on moss on boulder by pond, McCune 35035.

Toninia squalida (Ach.) A. Massal. - Lake Clark: bay on SW side of Portage Lake, on soil over rock, McCune 35157.

Toninia tristis (Th. Fr.) Th. Fr. - Lake Clark: shore of Lake Clark, W of Hatchet Point, on moss and soil over rock, McCune 35313.

Trapelia sp. - Katmai: alluvial flats near camp on E side of Hammersly Lake, on rock in frost boil, McCune 32958, Tonsberg 42810. This species has minute, very pale, marginate apothecia with reddish disks and much reduced thallus, soredia lacking. It was found colonizing otherwise bare rock. In the key in Orange (2018) it comes to T. glebulosa, but the morphology is unlike that species; TLC: gyrophoric $+5-O$-methylhiascic; genus uncertain; DNA sequencing unsuccessful so far.

Trapelia corticola Coppins \& P. James - Lake Clark: inlet at SW end of Pickerel Lake, on humus

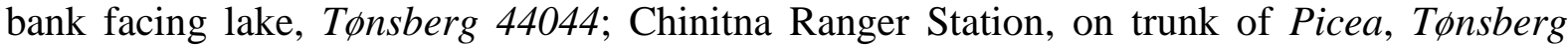
44359; shore of Lake Clark, stop 2, W of Hatchet Point, on moss on fallen trunk of Populus balsamifera, Tønsberg 44135; south end of Pickerel Lake, on rotten bark in cavity, Tфnsberg 44048.

Trapeliopsis flexuosa (Fr.) Coppins \& P. James - Katmai: ca. $800 \mathrm{~m} \mathrm{~S}$ of W end of Malone Lake, Tфnsberg 42961. Lake Clark: near SW end of Pickerel Lake, on wood, Rosentreter 18649; trail to Tanalian Falls from Port Alsworth, Rosentreter 18471.

Trapeliopsis gelatinosa (Flörke) Coppins \& P. James - Lake Clark: bay on SW side of Portage Lake, on soil and moss over rock, Tønsberg 43915; on wet, hanging mat of humus in deeply shaded ravine, Tonsberg 43962.

Trapeliopsis granulosa (Hoffm.) Lumbsch - Common on wood, humus, organic matter, and soil, low elevations to alpine.

Trapeliopsis pseudogranulosa Coppins \& P. James - Lake Clark: bay on SW side of Portage Lake, on Terricolous on humus rich, dry soil somewhat protected, Tønsberg $43903 b$.

Tremolecia atrata (Ach.) Hertel - Occasional on rock, especially iron-rich rock, low elevations to alpine.

Umbilicaria americana Poelt \& T. Nash - Katmai: near Cucumber Lake, on rock outcrop, Walton 13054. Lake Clark: Portage Lake, on rock outcrop, Walton 18958. Reported from Alaska by Stehn et al. (2015).

Umbilicaria arctica (Ach.) Nyl. - Occasional on rock in alpine, exposed or sheltered. One specimens sequenced (E. Davydov 2014) belongs to the Eurasian clade; another specimen sequenced by us (McCune 34978) belongs to a clade separate from $U$. hyperborea $+U$. arctica. This specimen has large, tough, thick thalli, heavily verrucose above and largely gray below.

Umbilicaria cinereorufescens (Schaerer) Frey - Occasional on rock, low elevations to alpine.

Umbilicaria cylindrica (L.) Delise ex Duby - Occasional on rock in alpine tundra.

Umbilicaria deusta (L.) Baumg. - Katmai: near Hammersly Lake, on rock, Walton 13133; near Malone Lake, on periodically inundated, rock, Walton 13133. Lake Clark: shoulder of mountain overlooking Tuxedni Bay, on rock, McCune 35481.

Umbilicaria dura McCune - Lake Clark: slopes and flats above Turquoise Lake, on semi-sheltered rock, McCune 34977, 35008; Tønsberg 43767. See full description in McCune (2018); also known from Oregon and Washington Cascades.

Umbilicaria hyperborea (Ach.) Hoffm. - Common on rock, low elevations to alpine. Some specimens are black below, approaching $U$. nylanderiana, but instead of being sooty black are either smooth or papillate. The ITS sequence of one of these (McCune 35477) confirmed placement in $U$. hyperborea.

Umbilicaria herrei Frey - Katmai: E of Hammersly Lake, $925 \mathrm{~m}$ and $1014 \mathrm{~m}$, on rock, Walton 16342, 16375. Lake Clark: $60.7597^{\circ} \mathrm{N}, 153.9287^{\circ} \mathrm{W}, 1280 \mathrm{~m}$, on rock, Walton 15966.

Umbilicaria lyngei Schol. - Lake Clark: slopes and flats above Turquoise Lake, on rock, McCune 34982. TLC: gyrophoric, lecanoric, and crustinic acids; DNA matches $U$. lyngei in GenBank 
(AF297669 from China), but the chemical contents are unlike that reported by Løfall \& Timdal (2005): "In Norway and Svalbard, gyrophoric acid was found to be constantly present in Umbilicaria decussata and constantly absent in $U$. lyngei, thus providing a diagnostic character for sterile, poorly developed specimens in this area." It seems possible that the specimen reported here and the Chinese GenBank record represent another species.

Umbilicaria multistrata McCune - Lake Clark: slopes and flats above Turquoise Lake, on rock, McCune 34957. See full description and additional specimens in McCune (2018); also known from Thompson Pass (near Valdez), Kenai Fjords National Park, and other Alaskan locations.

Umbilicaria proboscidea (L.) Schrader - Common on rock, especially in alpine tundra. Unusual morph: Katmai: ca. $1 \mathrm{~km} \mathrm{SW}$ of Malone Lake, on rock, granite boulder, McCune 34177. This form has small thalli, to ca. $1 \mathrm{~cm}$ diam, the edge minutely and heavily lobulate; otherwise the morphology and chemistry are consistent with $U$. proboscidea; DNA sequencing was unsuccessful.

Umbilicaria rigida (Du Rietz) Frey - Lake Clark: slopes and flats above Turquoise Lake, on rock, McCune 35009, 35010 (fertile; TLC of 35010: nil).

Umbilicaria torrefacta (Lightf.) Schrader - Common on rock, low elevations to more often alpine. A common variant here has a completely black lower surface but otherwise similar in thallus morphology and spores and does not separate in phylogenetic reconstructions based on ITS and nuLSU sequences (McCune 2018). See also U. dura and U. multistrata, which have a thick, tough, thallus and multilayered black lower surface (McCune 2018).

Umbilicaria vellea (L.) Hoffm. - Occasional on cliff faces, low elevations to alpine.

Usnea hirta (L.) F. H. Wigg. - Katmai: $57.9972^{\circ} \mathrm{N}, 155.0270^{\circ} \mathrm{W}$, large cliff area near ocean beach, on Alnus bark, Walton 18549 (medulla $\mathrm{P}-$, main axes not papillose).

Usnea lapponica Vainio - Common on various trees and shrubs at low elevations. TLC: usnic and salacinic acids (usually) or usnic acid only. Usnea generally has low abundance in the Parks; $U$. lapponica is clearly the most frequent species.

Usnea scabrata Nyl. - Katmai: SW shoreline of Coville Lake, on Picea glauca twig, Walton 13480. TLC: usnic and salacinic acids. Branches with scattered ridges; papillae low, not well developed.

Usnea subfloridana Stirton - Tuxedni: Chisik Island, on Populus trichocarpa, Talbot 88052-22 (not verified by us).

Varicellaria lactea (L.) Schmitt \& Lumbsch - Katmai: Naknek Lake, NNE of Brooks Camp, saxicolous in shallow cavity in lakeshore cliff, Tфnsberg 42724b. Lake Clark: bay on SW side of Portage Lake, on overhanging rock wall, Tønsberg 43909; Camel's Hump on shore of Lake Clark, on vertical rock wall at inner edge of lakeshore, Tønsberg 44076; see Tønsberg (2018) for further details and photo.

Varicellaria rhodocarpa (Körber) Th. Fr. - Occasional on various trees and shrubs at low elevations.

Variolaria - see Lepra

Verrucaria aethiobola Wahlenb. - Katmai: east side of Hammersly Lake, on shoreline cobbles, McCune 32976b, 32971, 32972a; Naknek Lake on peninsula NE of Brooks Camp, on lakeshore rock, McCune 32824a. Lake Clark: near campsite at NW end of Turquoise Lake, on lakeshore rock, McCune 35060; Lake Clark: Tanalian Falls SE of Port Alsworth, on rock, McCune 34910b.

Verrucaria funckii (Sprengel) Zahlbr. - Katmai: low rocky ridge NE of Mirror Lake, on stones in spring, McCune 32979c, 32980. Lake Clark: near mouth of Horn Creek E of Chinitna Ranger Station, on rock in creek, McCune 35628; shoulder of basin on E side of Saddle Mountain, on rock in rivulet, $\mathrm{McC}$ Cune $35455 \mathrm{~b}$.

Verrucaria fusca auct. - Lake Clark: near campsite at NW end of Turquoise Lake, parasitic on Aspicilia aquatica on rock, McCune 35074.

Verrucaria fuscoatroides Servít - Katmai: shoreline of Naknek Lake on peninsula NE of Brooks Camp, on shaded rock, McCune $32818 b$. 
Verrucaria margacea (Wahlenb.) Wahlenb. - Katmai: shoreline of Naknek Lake on peninsula NE of Brooks Camp, on rock, McCune 32795. Lake Clark: bay on SW side of Portage Lake, on wetted lakeshore boulder, McCune 35139; summit of Slope Mountain, overlooking Tuxedni Channel, on rock in seepage track, McCune $35427 b$.

Verrucaria memnonia (Flotow in Körber) Arnold - Lake Clark: bay on SW side of Portage Lake, on rock, McCune 35178.

Verrucaria nigrescens Pers. - Katmai: shoreline of Naknek Lake on peninsula NE of Brooks Camp, on lakeshore rock, McCune 32828b.

Verrucaria praetermissa (Trevisan) Anzi - Katmai: Headwaters Creek, SW of Malone Lake, on outcrop by creek, McCune 34202.

Violella fucata (Stirt.) T. Sprib. - Katmai: near Brooks Camp, S of Brooks River, along road and trail toward viewing platform, Tønsberg 42584; near shore of Naknek Lake, $\mathrm{N}$ of Brooks Camp, Tønsberg 42669. Lake Clark: Camel's Hump on shore of Lake Clark, on dead branch

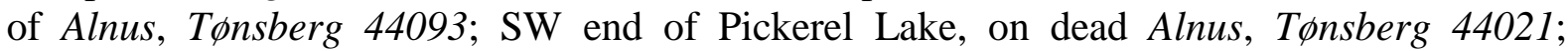
Tanalian Falls SE of Port Alsworth, on Betula neoalaskana, Tфnsberg 43707.

Xanthocarpia cf. crenulatella (Nyl.) Frödén, Arup \& Søchting - Lake Clark: shore of Lake Clark ca. $30 \mathrm{~km}$ NE of Port Alsworth, W of Hatchet Point, on rock, cliff face, McCune 35326.

Xanthocarpia erichansenii (Kondr. et al.) Arup \& Søchting - Lake Clark: shore of Lake Clark, W of Hatchet Point, on soil, Rosentreter 18789.

Xanthomendoza hasseana (Räsänen) Søchting, Kärnefelt \& S. Kondr. - Katmai: near National Park Service bunkhouse in King Salmon, on bark, Salix, McCune 32693.

Xanthoparmelia angustiphylla (Gyelnik) Hale - Lake Clark: Camel's Hump on shore of Lake Clark, Rosentreter 18779.

Xanthoparmelia coloradoensis (Gyelnik) Hale - Lake Clark: shore of Lake Clark, stop 2, W of Hatchet Point, on rock, lakeshore outcrops, McCune 35345.

Xanthoparmelia coloradoënsis (Gyelnik) Hale - Katmai: $58.7981 \mathrm{~N}^{\circ} 155.9732^{\circ} \mathrm{W}, 427 \mathrm{~m}$, on rock outcrop, Walton 13043 (TLC: usnic and salacinic acids); shoreline of Naknek Lake on peninsula NE of Brooks Camp, on rock, Spickerman 44. Lake Clark: shore of Lake Clark, W of Hatchet Point, on xeric boulder side, Walton 19116.

Xylographa hians Tuck. - Lake Clark: near SW end of Pickerel Lake, on wood, McCune 35233, 35234.

Xylographa parallela (Ach.: Fr.) Behlen \& Desberger - Lake Clark: Chinitna Ranger Station, on beach log, McCune 35669.

Xylographa trunciseda (Th. Fr.) Minks - Katmai: near Brooks Camp, S of Brooks River, along road and trail toward viewing platform, Tonsberg 42598.

Xylographa vermicularis T. Sprib. - Katmai: ca. $600 \mathrm{~m} \mathrm{~S}$ of W end of Malone Lake, Tønsberg 42942; near Brooks Camp, S of Brooks River, along road and trail toward viewing platform, Tфnsberg $42603 b$.

Xylographa vitiligo (Ach.) J. R. Laundon - Katmai: Katmai Bay Bear Cam, 58.0048 N, $155.0442^{\circ} \mathrm{W}, 18 \mathrm{~m}$, on Populus balsamifera wood, Walton 18624; near Brooks Camp, along road and trail toward viewing platform, Tonsberg 42603a. Lake Clark: Chinitna Ranger Station, on driftwood; huge trunk of Populus, Tфnsberg 44145.

Zahlbrucknerella calcarea (Herre) Herre - Lake Clark: shore of Lake Clark ca. $30 \mathrm{~km}$ NE of Port Alsworth, W of Hatchet Point, on rock, cliff face and wetted lakeshore marble, McCune $35336 b, 35323 c, 35321 b, 35329 a, 35308,35307 b, 35322 b$.

Zahlbrucknerella fabispora Henssen - Katmai: shoreline of Naknek Lake on peninsula NE of Brooks Camp, on lakeshore rock, McCune 32829 (det. Schultz). Minutely dwarf fruticose growth form with scytonematoid photobiont and collar like hyphae surrounding the threads. The threads are very thin, 35-65(80) $\mu \mathrm{m}$, so one arrives at Z. fabispora. The material is sterile, however, so bean shaped spores were not demonstrated. Rarely recorded and apparently new for Alaska. 


\section{Acknowledgments}

We thank the National Park Service in Anchorage, including Michael Shephard, and Chris Lauver in the Cooperative Ecosystem Studies Unit in Seattle, for sponsoring this project under Cooperative Agreement H8W07110001 with Oregon State University. We thank Astri Botnen, Irwin Brodo, Evgeny Davydov, Arve Elvebakk, Alan Fryday, Per Magnus Jørgensen, Helmut Mayrhofer, Zdenek Palice, Toby Spribille, Einar Timdal, and Tim Wheeler for providing identifications, advice, and specimens for comparison, and Joe Ammirati for identifications of conks. Einar also facilitated the loan of Krog specimens and data to BM. Leon Rogers and Dongling Niu assisted with thin-layer chromatography and DNA extraction, PCR, and sequencing. Carlos Jose Pardo De la Hoz helped with the identifications of P. leucophlebia and P. latiloba. Michele Wiseman and the Plant Clinic at OSU extracted, performed PCR and processed many sequences, as did Claudia Corvalán. We also thank Louise Lindblom at the DNA lab, University of Bergen, for sequencing. Tim Wheeler helped to place Aspicilia ITS sequences using his unpublished data. Kaleigh Spickerman (Maze) assisted with field work and initial data management. Numerous herbaria assisted, but we especially thank curators of WIS for arranging loans and visit by McCune for specimens from Tuxedni. Lisa Schomaker and Evan Heck ably assisted in the field.

\section{References}

Ahti T, Stenroos S. 2013 - Cladoniaceae. Pp 8-86 in Ahti T, Stenroos S, Moberg R, eds, Nordic Lichen Flora 5.

AKNHP. 2015 - Rare lichen list. Alaska Natural Heritage Program. http://accs.uaa.alaska.edu/botany/rare-lichen-list. Accessed 12 May 2016.

Alphandary E, McCune B. 2013 - A new chemical spot test for miriquidic acid. Lichenologist 45, 697-699.

Anderson F, Lendemer JC. 2016 - Aspicilia bicensis (Megasporaceae), a new sterile, pustulose lichen from eastern Canada. Bryologist 119, 8-15.

Aptroot A, Gilbert OL, Hawksworth DL, Coppins BJ 2009 - Lecidea. Pp 502-519 in Smith CW et al., eds, The Lichens of Great Britain and Ireland. British Lichen Society, London.

Arup U. 1994 - The genus Caloplaca on seashore rocks in eastern North America. Bryologist 96, 377-392.

Arup U, Vondrák J, Halici MG. 2015 - Parvoplaca nigroblastidiata, a new corticolous lichen (Teloschistaceae) in Europe, Turkey and Alaska. Lichenologist 47, 379-385.

Berg EE. 2006 - Unpublished species lists (lichen, bryophyte) from Katmai National Park and Preserve. National Park Service, Southwest Alaska Network, Anchorage, AK.

Bergamini A, Scheidegger C, Stofer S, Carvalho P et al. 2005 - Performance of macrolichens and lichen genera as indicators of lichen species richness and composition. Conservation Biology 19, 1051-1062.

Boggs K, Klein SC, Grunblatt J, Koltun B. 2003 - Landcover classes, ecoregions and plant associations of Katmai National Park and Preserve. National Park Service, Alaska Region, Anchorage, AK. http://aknhp.uaa.alaska.edu/wp-content/uploads/2011/10/2003-Boggs-et-al.Landcover-Classes-Ecoregions-PAs-KATM.pdf

Brodo IM. 1981 - Lecanora luteovernalis, a new species of the L. symmicta complex from the Canadian Arctic. Bryologist 84, 521-526.

Brodo IM. 1995 - Notes on the lichen genus Placopsis (Ascomycotina, Trapeliaceae) in North America. Pp. 59-70 in Knoph, J-G, Schrüfer K, Sipman HJM, eds., Studies in Lichenology with Emphasis on Chemotaxonomy, Geography and Phytochemistry. Bibliotheca Lichenologica, J. Cramer, Berlin.

Brodo IM, Hertel H. 1987 - The lichen genus Amygdalaria (Porpidiaceae) in North America. Herzogia 7, 493-521. 
Brodo IM, McCune B. 2017 - Ochrolechia brodoi, a new lichen for North America from Alaska, with updates to the key of corticolous North American species. Evansia 34, 110-113.

Cahalane V. 1959 - A biological survey of Katmai National Monument. Smithsonian Miscellaneous Collections 138(5), 1-246.

Commission for Environmental Cooperation 2011 - North American Terrestrial Ecoregions-Level III. Montreal, Quebec.

Connor C. 2014 - Roadside Geology of Alaska. Mountain Press, Missoula, Montana.

Cummings CE. 1904 - The Lichens of Alaska. pp. 67-149 in Harriman Alaska Expedition, Vol. V. Cryptogamic Botany. Doubleday, NY.

Culberson CF. 1972 - Improved conditions and new data for the identification of lichen products by a standardized thin-layer chromatographic method. Journal of Chromatography 72, 113125.

Culberson CF, Johnson A. 1982 - Substitution of methyl tert-butyl ether for diethyl ether in standardized thin-layer chromatographic method for lichen products. Journal of Chromatography 238, 483-487.

Culberson CF, Kristinsson H. 1970 - A standardized method for the identification of lichen products. Journal of Chromatography 46, 85-93.

Dillman K. 2003 - Lichens of Rock Art Sites from Lake Clark National Park. Unpublished report prepared for Shah Conservation, Anchorage. 19 pp.

Divakar PK, Crespo A, Kraichak E, Leavitt SD et al. 2017 - Using a temporal phylogenetic method to harmonize family and genus-level classification in the largest clade of lichen-forming fungi. Fungal Diversity 84, 101. DOI 10.1007/s13225-017-0379-z

Esslinger TL, McCune B, Haughland DL. 2017 - Physconia labrata, a new species from western North America and Asia. Bryologist 120, 427-434.

Fierstein J, Hildreth W. 1992 - Preliminary volcano-hazard assessment for the Katmai Volcanic Cluster, Alaska. Open-File Report 00-489. U.S. Geological Survey, Alaska Volcano Observatory, Anchorage, Alaska.

Fryday AM. 2005 - The genus Porpidia in northern and western Europe, with special emphasis on collections from the British Isles. Lichenologist 37, 1-35.

Fryday AM, Tønsberg T. 2015 - Ameliella - a bryicolous lichen genus rediscovered in North America after 50 years. Evansia 32, 171-175.

Geiser LH, Jovan SE, Glavich DA, Porter MK. 2010 - Lichen-based critical loads for atmospheric nitrogen deposition in western Oregon and Washington forests, USA. Environmental Pollution 158, 2412-2421.

Geiser LH, Neitlich PN. 2007 - Air pollution and climate gradients in western Oregon and Washington indicated by epiphytic macrolichens. Environmental Pollution 145, 203-218.

Gilbert OL, Coppins BJ. 2009 - Ptychographa. Pp 768-769 in Smith CW et al., eds, The Lichens of Great Britain and Ireland. British Lichen Society, London.

Griggs RF. 1922 - The Valley of Ten Thousand Smokes. National Geographic Society, Washington, DC. 340 p.

Griggs RF. 1936 - The vegetation of the Katmai District. Ecology 17, 380-417.

Gunther AJ. 1986. Report to the National Park Service on Research Performed Under Contract at Katmai National Park, Alaska, During the Summer of 1986. Univ. California, Berkeley.

Gunther AJ. 1987a - Nitrogen Cycling in a Subarctic Alaskan Watershed: The Role of Lichens and the Potential Effects of Acid Deposition. PhD Dissertation. University of California, Berkeley.

Gunther AJ. 1987b - Nitrogen Fixation by Lichens in a Subarctic Alaskan Watershed. Bryologist 92, 202-208.

Hasselbach LM. 1995 - Vascular and nonvascular vegetation of the Caldera of Mt. Aniakchak, Alaska. M. S. Thesis. https://ir.library.oregonstate.edu/xmlui/handle/1957/35523

Holtan-Hartwig J. 1993 - The lichen genus Peltigera, exclusive of the P. canina group, in Norway. Sommerfeltia 15, 1-77. 
Holtan-Hartwig J. 2005 - Peltigera latiloba, a new lichen species from Norway and USA (Alaska). Graphis Scripta. 17, 34-34.

Hultén E. 1941 - Flora of Alaska and Yukon. I. - Lunds University Arsskr. N. F. Avd. 2 37, 1-127.

Joneson S, Kashiwadani H, Tschabanenko S, Gage S. 2004 - Ramalina of the Kuril Islands. Bryologist 107, 98-106.

Jorgenson T, Yoshikawa K, Kanevskiy M, Shur Y et al. 2008 - Permafrost characteristics of Alaska. University of Alaska Fairbanks. December update to July NICOP map.

Krog H. 1968 - The Macrolichens of Alaska. Norsk Polarinstitut. Skrifter Nr. 144. Oslo, Norway.

Lamb IM. 1977 - A conspectus of the lichen genus Stereocaulon (Schreb.) Hoffm. Journal of the Hattori Botanical Laboratory 43, 191-355.

Leavitt SD, Divakar PK, Crespo A, Lumbsch HT. 2016 - A matter of time - understanding the limits of the power of molecular data for delimiting species boundaries. Herzogia 29, 479492.

Lendemer JC. 2013 - A monograph of the crustose members of the genus Lepraria Ach. s. str. (Stereocaulaceae, Lichenized Ascomycetes) in North America north of Mexico. Opuscula Philolichenum 11, 27-141.

Løfall BP, Timdal E. 2005 - Umbilicaria decussata and U. lyngei in Norway and Svalbard. Graphis Scripta 17, 43-47.

Lücking R, Moncada B, McCune B, Farkas E et al. 2017 - Pseudocyphellaria crocata (Ascomycota: Lobariaceae) in the Americas is revealed to be thirteen species, and none of them is $P$. crocata. Bryologist $120,441-500$.

Lynge B. 1940 - Lichens from North East Greenland collected on the Norwegian scientific expeditions in 1929 and 1930. II. Microlichens. Skrifter om Svalbard og Ishavet 81, 1-143.

Magain N, Sérusiaux E, Zhurbenko MP, Lutzoni F, Miadlikowska J. 2016 - Disentangling the Peltigera polydactylon species complex by recognizing two new taxa, $P$. polydactylon subsp. udeghe and P. seneca. Herzogia 29, 514-528.

Magain N, Miadlikowska J, Goffinet B, Sérusiaux E, Lutzoni F. 2017a - Macroevolution of specificity in cyanolichens of the genus Peltigera Section Polydactylon (Lecanoromycetes, Ascomycota). Systematic Biology 66, 74-99.

Magain N, Miadlikowska J, Mueller O, Gajdeczka M et al. 2017b - Conserved genomic collinearity within and among Pezizomycotina classes to develop broadly applicable, fast evolving, markers to resolve species complexes: a case study using the lichen-forming genus Peltigera section Polydactylon. Molecular Biology and Evolution 117, 10-29.

Magain N, Truong C, Goward T, Niu D et al. 2018 - Global species delimitation of Peltigera section Peltigera (lichenized Ascomycota, Lecanoromycetes) reveals high species richness with complex biogeographical history and symbiotic patterns of associations. Taxon (in review).

Magnusson AH. 1952 - Lichens from Torne Lappmark. Arkiv för Botanik, ser. 2 2(2), 45- 249.

Mayrhofer H, Moberg R. 2002 - Rinodina. Nordic Lichen Flora 2, 41-69.

Mayrhofer H, Sheard JW. 1988 - Four notable saxicolous species of the lichenized Ascomycete genus Rinodina from the Arctic. Bryologist 91, 106-112.

McCune B. 2017 - Microlichens of the Pacific Northwest. Volumes 1 and 2. Wild Blueberry Media, Corvallis, Oregon.

McCune B. 2018 - Two new species in the Umbilicaria torrefacta group from Alaska and the Pacific Northwest of North America. Ms.

McCune B, Curtis MJ, Di Meglio J. 2017 - New taxa and a case of ephemeral spore production in Lecideaceae from western North America. Bryologist 120, 115-124.

McCune B, Timdal E, Bendiksby M. 2016 - Rhizocarpon quinonum, a new anthraquinonecontaining species from the Alaska Peninsula. Lichenologist 48, 367-375.

Miadlikowska J, Lutzoni F. 2000 - Phylogenetic revision of the genus Peltigera (lichen-forming Ascomycota) based on morphological, chemical, and large subunit nuclear ribosomal DNA data. International Journal of Plant Science 161, 925-958. 
Miller AE, Carlson M, Lipkin R, Spencer P. 2006 - Vascular plant inventory and baseline monitoring of nunatak communities (2005). Lake Clark National Park and Preserve and Kenai Fjords National Park. Southwest Alaska Network, National Park Service. Anchorage, AK.

Miller AE, Walton JK, Moore C, Thompson WL. 2010 - Vegetation composition and structure: baseline monitoring in the Southwest Alaska Network - 2009 annual summary report. Natural Resource Technical Report NPS/SWAN/NRTR-2010/342. National Park Service, Fort Collins, Colorado.

Miller AE, Walton JK, Moore C, Thompson WL. 2011 - Vegetation composition and structure: baseline monitoring in the Southwest Alaska Network - 2010 annual summary report. Natural Resource Technical Report NPS/SWAN/NRTR-2011/449. National Park Service, Fort Collins, Colorado.

Miller AE, Walton JK. 2013 - Vegetation monitoring - Southwest Alaska Network: 2012 annual report, natural Resource Data Series NPS/SWAN/NRDS-2-13/521. National Park Service, Fort Collins, Colorado.

Miller AE, Sherriff RL, Berg EE. 2012 - Effect of the Novarupta (1912) eruption on forests of southcentral Alaska: Clues from the tree ring record. Alaska Park Science 11(1), 75-77. http://www.nps.gov/akso/nature/science/ak_park_science/PDF/2012Vol11-1/12-Miller-APSV11-I1.pdf

Nelsen MP, Chavez N, Sackett-Hermann E, Thell A et al. 2011 - The cetrarioid core group revisited (Lecanorales: Parmeliaceae). Lichenologist 43, 537-551.

Nelson PR, Walton J, Root H, Spribille T. 2011 - Hypogymnia pulverata (Parmeliaceae) and Collema leptaleum (Collemataceae), two macrolichens new to Alaska. North American Fungi $6,1-8$.

Nowacki G, Spencer P, Brock T, Fleming M, Jorgenson T. 2010 - Ecoregions of Alaska and Neighboring Territory. U.S. Geological Survey and U. S. Environmental Protection Agency, ArcGIS Layer Package.

Onut-Brannstrom I, Tibell L, Johannesson H. 2017 - A worldwide phylogeography of the whiteworm lichens Thamnolia reveals three lineages with distinct habitats and evolutionary histories. Ecology and Evolution 7, 3602-3615.

Orange A. 2018 - A new species-level taxonomy for Trapelia (Trapeliaceae, Ostropomycetidae) with special reference to Great Britain and the Falkland Islands. Lichenologist 50, 3-42.

Otálora MAG, Jørgensen PM, Wedin M. 2014 - A revised generic classification of the jelly lichens, Collemataceae. Fungal Diversity 64, 275-293.

PRISM 2009 - Gridded climate data for Alaska (1971-2000). PRISM Climate Group, Oregon State University, and National Park Service, Alaska Region Inventory and Monitoring Program. http://irma.nps.gov/, created 1 December 2009.

Resl P, Clayden SR, Mayrhofer H, Spribille T et al. 2016 - Morphological, chemical and species delimitation analyses provide new taxonomic insights into two groups of Rinodina. Lichenologist 48, 469-488.

Schindler H. 1990 - Beitrag zur Flechtenflora von Alaska (Pribilof-Insel St. Paul; KenaiHalbinsel; Katmai Nat. Park und Denali Nat. Park). Herzogia 8, 335-356.

Sheard JW. 2010 - The lichen genus Rinodina (Ach.) Gray (Lecanoromycetidae, Physciaceae) in North America, north of Mexico. National Research Council Canada, Ottawa.

Sheard JW. 2018 - A synopsis and new key to the species of Rinodina (Ach.) Gray (Physciaceae, lichenized Ascomycetes) presently recognized in North America. Herzogia (in press).

Sheard JW, Ezhkin AK, Galanina IA, Himelbrant D et al. 2017 - The lichen genus Rinodina (Physciaceae, Caliciales) in northeast Asia. Lichenologist 49, 617-672.

Sheard JW, McCune B, Tønsberg T. 2014 - A new corticolous species of Rinodina (Physciaceae) and two interesting range extensions for species collected from Katmai National Park, Alaska. Bryologist 117, 253-258. 
Shephard ME. 2000 - Ecological subsections of Katmai National Park and Preserve, Alagnak Wild River, Alaska. National Park Service, Anchorage.

http://www.arlis.org/docs/vol1/122443531.pdf

Sliwa L, Wetmore CM. 2000 - Notes on the Lecanora varia group in North America. Bryologist $103,475-492$.

Spickerman K. 2015 - Lichen functional trait variation along an east-west climatic gradient in Oregon and among habitats in Katmai National Park, Alaska. MS Thesis, Oregon State University.

Spribille T, Pérez-Ortega S, Tønsberg T, Schirokauer D. 2010 - Lichens and lichenicolous fungi of the Klondike Gold Rush National Historic Park, Alaska, in a global biodiversity context. Bryologist 113, 439-515.

Stehn SE, Walton JK, Nelson PR, Hampton-Miller CJ, Roland CA. 2015 - A lichen species list for Denali National Park and Preserve, Alaska, with comments on several new and noteworthy records. Evansia 32, 195-215.

Stone DF, Hinds JW, Anderson FL, Lendemer JC. 2016 - A revision of the Leptogium saturninum group in North America. Lichenologist 48, 387-422.

Talbot SS, Talbot SL, Thomson JW. 1992 - Lichens of Tuxedni Wilderness Area, Alaska. Bryologist 95, 20-30.

Thomson JW. 1984 - American Arctic Lichens, Vol. 1: The Macrolichens. Columbia University Press, New York.

Thomson JW. 1997 - American Arctic Lichens II. Crustose Lichens. University of Wisconsin Press, Madison.

Tønsberg T. 1992 - The sorediate and isidiate, corticolous, crustose lichens in Norway. Sommerfeltia 14, 1-331.

Tønsberg T. 2018 - Varicellaria lactea new to North America from USA, Alaska. Opuscula Philolichenum 17, 1-5.

Tønsberg T, Timdal E, McCune B. 2018 - Rhizocarpon isidiatum, a new lichen species from USA, Alaska. Manuscript.

Zahradníková M, Andersen HL, Tønsberg T. 2018 - Fuscidea lightfootii and F. pusilla (Fuscideaceae, Umbilicariomycetidae, Ascomycota), two similar, but genetically distinct species. Lichenologist (in press).

Zhao X, Leavitt SD, Zhao ZT, Zhang LL et al. 2016 - Towards a revised generic classification of lecanoroid lichens (Lecanoraceae, Ascomycota) based on molecular, morphological and chemical evidence. Fungal Diversity. 78, 293-304.

\section{Appendix 1 Group collecting sites visited in summer 2013 and 2014.}

\begin{tabular}{|c|c|c|c|c|c|c|c|c|}
\hline $\begin{array}{l}\text { Site } \\
\text { group }\end{array}$ & $\begin{array}{l}\text { Waypoint } \\
\text { cluster }\end{array}$ & Latitude & Longitude & $\begin{array}{c}\text { Elev. } \\
\text { m }\end{array}$ & $\begin{array}{c}\text { Species } \\
\text { count }\end{array}$ & $\begin{array}{l}\text { Specimens } \\
\text { IDd to } \\
\text { species }\end{array}$ & Location & Habitat \\
\hline & & & & \multicolumn{5}{|c|}{ Katmai NP } \\
\hline 1 & 97 & 58.68126 & -156.66905 & 12 & 27 & 34 & $\begin{array}{l}\text { Near National Park } \\
\text { Service bunkhouse in } \\
\text { King Salmon }\end{array}$ & $\begin{array}{l}\text { Picea glauca - } \\
\text { Salix - Alnus } \\
\text { forest with boggy } \\
\text { openings }\end{array}$ \\
\hline 2 & 103 & 58.55116 & -155.77743 & 18 & 65 & 97 & $\begin{array}{l}\text { Near Brooks Camp, } S \\
\text { of Brooks River, along } \\
\text { road and trail toward } \\
\text { viewing platforms }\end{array}$ & $\begin{array}{l}\text { Picea glauca } \\
\text { forest and edge of } \\
\text { fen }\end{array}$ \\
\hline 2 & 103 & 58.55120 & -155.78620 & 18 & $\begin{array}{c}\text { with } \\
\text { above }\end{array}$ & with above & $\begin{array}{l}\text { Near Brooks Camp, } S \\
\text { of Brooks River, along } \\
\text { road and trail toward } \\
\text { viewing platforms }\end{array}$ & $\begin{array}{l}\text { Picea glauca } \\
\text { forest with moss } \\
\text { undergrowth and } \\
\text { minimal woody } \\
\text { understory }\end{array}$ \\
\hline
\end{tabular}


Appendix 1 Continued.

\begin{tabular}{|c|c|c|c|c|c|c|c|c|}
\hline $\begin{array}{l}\text { Site } \\
\text { group }\end{array}$ & $\begin{array}{l}\text { Waypoint } \\
\text { cluster }\end{array}$ & Latitude & Longitude & $\begin{array}{c}\text { Elev. } \\
\text { m }\end{array}$ & $\begin{array}{c}\text { Species } \\
\text { count }\end{array}$ & $\begin{array}{l}\text { Specimens } \\
\text { IDd to } \\
\text { species }\end{array}$ & Location & Habitat \\
\hline & & & & \multicolumn{5}{|c|}{ Katmai NP } \\
\hline 2 & 114 & 58.55748 & -155.77822 & 14 & 62 & 89 & $\begin{array}{l}\text { near shore of Naknek } \\
\text { Lake, N of Brooks } \\
\text { Camp }\end{array}$ & $\begin{array}{l}\text { Betula-Picea } \\
\text { forest }\end{array}$ \\
\hline 2 & 120 & 58.56411 & -155.75843 & 12 & 86 & 128 & $\begin{array}{l}\text { Shoreline of Naknek } \\
\text { Lake on peninsula NE } \\
\text { of Brooks Camp }\end{array}$ & $\begin{array}{l}\text { Noncalcareous } \\
\text { rock outcrops and } \\
\text { boulders }\end{array}$ \\
\hline 2 & 127 & 58.56264 & -155.77521 & 18 & 62 & 86 & $\begin{array}{l}\text { Shore of Naknek Lake, } \\
\text { bay just north of } \\
\text { Brooks Camp, below } \\
\text { crumbling outcrops }\end{array}$ & $\begin{array}{l}\text { Populus forest } \\
\text { with occasional } \\
\text { Salix }\end{array}$ \\
\hline 2 & 133 & 58.54612 & -155.78578 & 30 & 24 & 32 & $\begin{array}{l}\text { Near gravel road } \\
\text { between Naknek Lake } \\
\text { and Lake Brooks }\end{array}$ & $\begin{array}{l}\text { Picea glauca } \\
\text { forest with sparse } \\
\text { undergrowth and } \\
\text { thick moss layer }\end{array}$ \\
\hline 3 & 138 & 58.86171 & -155.13988 & 494 & 34 & 36 & $\begin{array}{l}\text { Alluvial flats near } \\
\text { camp on east side of } \\
\text { Hammersly Lake }\end{array}$ & $\begin{array}{l}\text { dwarf shrub } \\
\text { tundra and Salix } \\
\text { thickets, with frost } \\
\text { boils and pits }\end{array}$ \\
\hline 3 & 144 & 58.86259 & -155.11619 & 740 & 73 & 135 & $\begin{array}{l}\text { Alpine ridge above } \\
\text { Hammersly Lake }\end{array}$ & $\begin{array}{l}\text { dwarf shrub } \\
\text { tundra }\end{array}$ \\
\hline 3 & 150 & 58.85312 & -155.09909 & 700 & 3 & 3 & $\begin{array}{l}\text { West slope not far } \\
\text { below ridge above } \\
\text { Hammersly Lake }\end{array}$ & $\begin{array}{l}\text { Outcrops, } \\
\text { boulders, } \\
\text { solifluction lobes, } \\
\text { and seeps on } \\
\text { moderate slope in } \\
\text { tundra }\end{array}$ \\
\hline 3 & 152 & 58.85334 & -155.10410 & $\begin{array}{l}\text { ca. } \\
620\end{array}$ & 7 & 7 & $\begin{array}{l}\text { Midslope below ridge } \\
\text { above Hammersly } \\
\text { Lake }\end{array}$ & $\begin{array}{l}\text { Shrub thickets and } \\
\text { dwarf shrub } \\
\text { tundra }\end{array}$ \\
\hline 3 & 157 & 58.86253 & -155.14459 & 489 & 26 & 38 & $\begin{array}{l}\text { Shoreline near camp } \\
\text { on east side of } \\
\text { Hammersly Lake }\end{array}$ & $\begin{array}{l}\text { noncalcareous } \\
\text { cobble beach }\end{array}$ \\
\hline 4 & 164 & 59.24367 & -154.72680 & 542 & 6 & 7 & $\begin{array}{l}\text { gentle slopes } \\
\text { approaching low rocky } \\
\text { ridge NE of Mirror } \\
\text { Lake }\end{array}$ & $\begin{array}{l}\text { Dwarf shrub } \\
\text { tundra with rocky } \\
\text { areas }\end{array}$ \\
\hline 4 & 167 & 59.24350 & -154.72287 & 565 & 65 & 88 & $\begin{array}{l}\text { Low rocky ridge NE of } \\
\text { Mirror Lake }\end{array}$ & $\begin{array}{l}\text { Coarse talus, } \\
\text { boulders, and } \\
\text { bedrock }\end{array}$ \\
\hline 4 & 172 & 59.24038 & -154.76293 & 393 & 23 & 27 & $\begin{array}{l}\text { Shoreline near camp } \\
\text { on north side of Mirror } \\
\text { Lake }\end{array}$ & $\begin{array}{l}\text { Noncalcareous } \\
\text { cobble and } \\
\text { boulder beach }\end{array}$ \\
\hline 4 & 173 & 59.24231 & -154.75955 & 409 & 50 & 63 & $\begin{array}{l}\text { ca. } 200 \mathrm{~m} \text { north of } \\
\text { Mirror Lake camp }\end{array}$ & $\begin{array}{l}\text { Frost boils and } \\
\text { streamlet in dwarf } \\
\text { shrub tundra }\end{array}$ \\
\hline 4 & 182 & 59.24524 & -154.75138 & 455 & 15 & 24 & $\begin{array}{l}\text { ca. } 600 \mathrm{~m} \text { north of } \\
\text { Mirror Lake camp }\end{array}$ & $\begin{array}{l}\text { Gentle slopes with } \\
\text { dwarf shrub } \\
\text { tundra, boulders, } \\
\text { and willow } \\
\text { thickets along } \\
\text { streams }\end{array}$ \\
\hline 5 & 188 & 58.26275 & -155.88651 & 1126 & 67 & 111 & $\begin{array}{l}\text { Ridgetop west of } \\
\text { Contact Creek }\end{array}$ & $\begin{array}{l}\text { Very rocky alpine } \\
\text { fellfield and } \\
\text { outcrops }\end{array}$ \\
\hline 5 & 200 & 58.26553 & -155.88390 & 1140 & 22 & 25 & $\begin{array}{l}\text { North end of ridge } \\
\text { west of Contact Creek }\end{array}$ & $\begin{array}{l}\text { Cliffs and alpine } \\
\text { fellfield }\end{array}$ \\
\hline
\end{tabular}


Appendix 1 Continued.

\begin{tabular}{|c|c|c|c|c|c|c|c|c|}
\hline $\begin{array}{l}\text { Site } \\
\text { group }\end{array}$ & $\begin{array}{l}\text { Waypoint } \\
\text { cluster }\end{array}$ & Latitude & Longitude & $\begin{array}{c}\text { Elev. } \\
\text { m }\end{array}$ & $\begin{array}{l}\text { Species } \\
\text { count }\end{array}$ & $\begin{array}{l}\text { Specimens } \\
\text { IDd to } \\
\text { species }\end{array}$ & Location & Habitat \\
\hline & & & & \multicolumn{5}{|c|}{ Katmai NP } \\
\hline 7 & 998 & 58.683403 & -156.34218 & 11 & & & $\begin{array}{l}\text { S shore Naknek Lake } \\
\text { near } 1.3 \mathrm{~km} \mathrm{~S} \text { of Gull } \\
\text { Island }\end{array}$ & $\begin{array}{l}\text { Stunted, old } \\
\text { Populus } \\
\text { balsamifera } \\
\text { forest. Collections } \\
\text { by Peter Nelson } \\
\text { only }\end{array}$ \\
\hline 7 & 999 & 58.690129 & -156.37639 & 11 & & & $\begin{array}{l}\text { S shore Naknek L. } \\
\text { near Grandma's Rock } \\
\text { about } 5.1 \mathrm{~km} \text { from } \\
\text { boat launch }\end{array}$ & $\begin{array}{l}\text { Tall willows and } \\
\text { stunted, old } \\
\text { Populus } \\
\text { balsamifera. } \\
\text { Collections by } \\
\text { Peter Nelson only }\end{array}$ \\
\hline 6 & 203 & 58.39735 & -156.15277 & 85 & 28 & 32 & $\begin{array}{l}\text { Camp at west end of } \\
\text { Malone Lake }\end{array}$ & $\begin{array}{l}\text { lichen woodland } \\
\text { with scattered } \\
\text { Picea and Betula }\end{array}$ \\
\hline 6 & 207 & 58.39330 & -156.15160 & 97 & 18 & 23 & $\begin{array}{l}\text { ca. } 300 \mathrm{~m} \mathrm{~S} \text { of W end } \\
\text { of Malone Lake }\end{array}$ & $\begin{array}{l}\text { Low, stony hill } \\
\text { with scattered } \\
\text { Picea and Betula }\end{array}$ \\
\hline 6 & 208 & 58.39216 & -156.15153 & 95 & 40 & 47 & $\begin{array}{l}\text { ca. } 600 \mathrm{~m} \mathrm{~S} \text { of } \mathrm{W} \text { end } \\
\text { of Malone Lake }\end{array}$ & $\begin{array}{l}\text { Moist depressions } \\
\text { with Picea and } \\
\text { shrub thickets }\end{array}$ \\
\hline 6 & 211 & 58.38925 & -156.15284 & 112 & 32 & 39 & $\begin{array}{l}\text { ca. } 800 \mathrm{~m} \mathrm{~S} \text { of W end } \\
\text { of Malone Lake }\end{array}$ & $\begin{array}{l}\text { Lichen woodland } \\
\text { with Picea clumps } \\
\text { and exposed dead } \\
\text { wood }\end{array}$ \\
\hline 6 & 215 & 58.38889 & -156.15397 & 117 & 7 & 8 & $\begin{array}{l}\text { ca. } 850 \mathrm{~m} \mathrm{~S} \text { of W end } \\
\text { of Malone Lake }\end{array}$ & $\begin{array}{l}\text { Low gravelly hill } \\
\text { with scattered } \\
\text { Picea }\end{array}$ \\
\hline 6 & 221 & 58.38734 & -156.16143 & 129 & 32 & 33 & $\begin{array}{l}\text { ca. } 1 \mathrm{~km} \mathrm{SW} \text { of } \\
\text { Malone Lake }\end{array}$ & $\begin{array}{l}\text { lichen woodland } \\
\text { with large granite } \\
\text { boulders and } \\
\text { clumps of Picea }\end{array}$ \\
\hline 6 & 224 & 58.38467 & -156.17887 & 112 & 33 & 50 & $\begin{array}{l}\text { Headwaters Creek, SW } \\
\text { of Malone Lake }\end{array}$ & $\begin{array}{l}\text { Riparian forest } \\
\text { with Populus, } \\
\text { Betula, and Picea }\end{array}$ \\
\hline 6 & 231 & 58.40080 & -156.15135 & 83 & 16 & 16 & $\begin{array}{l}\text { Near NW shore of } \\
\text { Malone Lake }\end{array}$ & $\begin{array}{l}\text { Lakeshore lichen } \\
\text { woodland and } \\
\text { eroding peaty } \\
\text { shoreline }\end{array}$ \\
\hline 6 & 232 & 58.40167 & -156.13250 & 80 & 23 & 34 & $\begin{array}{l}\text { NE side of Malone } \\
\text { Lake }\end{array}$ & $\begin{array}{l}\text { Picea - Betula } \\
\text { forest and } \\
\text { adjacent openings }\end{array}$ \\
\hline 6 & 234 & 58.39727 & -156.15149 & 81 & 2 & 2 & $\begin{array}{l}\text { West shore of Malone } \\
\text { Lake }\end{array}$ & $\begin{array}{l}\text { Beach cobbles } \\
\text { and eroding peaty } \\
\text { bank }\end{array}$ \\
\hline & & & & & & & $\begin{array}{l}\text { Lake Clark } \\
\text { National Park }\end{array}$ & \\
\hline 9 & 478 & 60.18411 & -154.26812 & 134 & 70 & 91 & $\begin{array}{l}\text { Tanalian Falls on } \\
\text { Tanalian River SE of } \\
\text { Port Alsworth }\end{array}$ & $\begin{array}{l}\text { Open streamside } \\
\text { Picea-Betula } \\
\text { forest }\end{array}$ \\
\hline 9 & 483 & 60.18724 & -154.27248 & 179 & 8 & 8 & $\begin{array}{l}\text { Near trail to Tanalian } \\
\text { Falls from Port } \\
\text { Alsworth }\end{array}$ & $\begin{array}{l}\text { open bog with } \\
\text { stony patches, } \\
\text { surrounded by } \\
\text { forest }\end{array}$ \\
\hline 9 & 485 & 60.19573 & -154.29758 & 160 & 52 & 61 & $\begin{array}{l}\text { Trail to Tanalian Falls } \\
\text { from Port Alsworth }\end{array}$ & $\begin{array}{l}\text { Picea-Betula } \\
\text { forest }\end{array}$ \\
\hline
\end{tabular}


Appendix 1 Continued.

\begin{tabular}{|c|c|c|c|c|c|c|c|c|}
\hline $\begin{array}{l}\text { Site } \\
\text { group }\end{array}$ & $\begin{array}{l}\text { Waypoint } \\
\text { cluster }\end{array}$ & Latitude & Longitude & $\begin{array}{c}\text { Elev. } \\
\text { m }\end{array}$ & $\begin{array}{c}\text { Species } \\
\text { count }\end{array}$ & $\begin{array}{l}\text { Specimens } \\
\text { IDd to } \\
\text { species }\end{array}$ & Location & Habitat \\
\hline & & & & & & & $\begin{array}{l}\text { Lake Clark } \\
\text { National Park }\end{array}$ & \\
\hline 10 & 497 & 60.80751 & -153.99478 & 990 & 133 & 207 & $\begin{array}{l}\text { slopes and flats above } \\
\text { Turquoise Lake }\end{array}$ & $\begin{array}{l}\text { Alpine tundra } \\
\text { with } \\
\text { noncalcareous } \\
\text { boulders and } \\
\text { outcrops }\end{array}$ \\
\hline 10 & 510 & 60.80911 & -154.00754 & 962 & 9 & 10 & $\begin{array}{l}\text { Small drainage on } \\
\text { slope above NW side } \\
\text { of Turquoise Lake }\end{array}$ & $\begin{array}{l}\text { Riparian shrubs, } \\
\text { rocky stream bed, } \\
\text { and outcrops }\end{array}$ \\
\hline 10 & 512 & 60.78778 & -154.00646 & 767 & 84 & 117 & $\begin{array}{l}\text { Near campsite at NW } \\
\text { end of Turquoise Lake }\end{array}$ & $\begin{array}{l}\text { Alpine tundra, } \\
\text { shoreline rocks, } \\
\text { and dwarf Betula } \\
\text { thickets }\end{array}$ \\
\hline 10 & 527 & 60.78525 & -154.01230 & 767 & 13 & 15 & $\begin{array}{l}\text { West side of Turquoise } \\
\text { Lake }\end{array}$ & $\begin{array}{l}\text { Alpine tundra and } \\
\text { dwarf Betula } \\
\text { thickets }\end{array}$ \\
\hline 10 & 997 & 60.78154 & -154.01191 & 765 & 34 & 34 & $\begin{array}{l}\text { Near outlet of } \\
\text { Turquoise Lake }\end{array}$ & $\begin{array}{l}\text { Lakeshore } \\
\text { boulders and } \\
\text { stony, hummocky } \\
\text { ground, alpine } \\
\text { tundra }\end{array}$ \\
\hline 11 & 537 & 60.50132 & -153.87719 & 450 & 115 & 163 & $\begin{array}{l}\text { Bay on SW side of } \\
\text { Portage Lake }\end{array}$ & $\begin{array}{l}\text { Cliffs and broken } \\
\text { Picea forest near } \\
\text { shore }\end{array}$ \\
\hline 11 & 994 & 60.50782 & -153.88320 & 447 & 17 & 21 & $\begin{array}{l}\text { near west end of } \\
\text { Portage Lake }\end{array}$ & $\begin{array}{l}\text { Populus } \\
\text { balsamifera forest }\end{array}$ \\
\hline 11 & 995 & 60.50717 & -153.88783 & 444 & 10 & 18 & $\begin{array}{l}200 \mathrm{~m} \text { west of west } \\
\text { end of Portage Lake }\end{array}$ & $\begin{array}{l}\text { Picea glauca } \\
\text { forest }\end{array}$ \\
\hline 11 & 996 & 60.50444 & -153.88116 & 450 & 2 & 2 & $\begin{array}{l}\text { SW corner of Portage } \\
\text { Lake }\end{array}$ & $\begin{array}{l}\text { Lakeshore } \\
\text { outcrops and } \\
\text { broken Picea } \\
\text { forest }\end{array}$ \\
\hline 12 & 552 & 59.94621 & -154.75756 & 86 & 75 & 112 & $\begin{array}{l}\text { Near SW end of } \\
\text { Pickerel Lake }\end{array}$ & $\begin{array}{l}\text { Picea woodland } \\
\text { and lakeshore }\end{array}$ \\
\hline 12 & 557 & 59.94497 & -154.75343 & 86 & 17 & 21 & $\begin{array}{l}\text { Inlet at SW end of } \\
\text { Pickerel Lake }\end{array}$ & $\begin{array}{l}\text { broken Picea- } \\
\text { Betula forest }\end{array}$ \\
\hline 12 & 561 & 59.94524 & -154.74638 & 86 & 10 & 18 & $\begin{array}{l}\text { South end of Pickerel } \\
\text { Lake }\end{array}$ & $\begin{array}{l}\text { Gravelly moraine } \\
\text { and wave-cut } \\
\text { lakeshore }\end{array}$ \\
\hline 12 & 564 & 59.94460 & -154.74130 & 95 & 25 & 28 & $\begin{array}{l}\text { Low ridge above inlet } \\
\text { stream to Pickerel } \\
\text { Lake }\end{array}$ & $\begin{array}{l}\text { Isolated Picea } \\
\text { grove and } \\
\text { woodland on sand } \\
\text { hill }\end{array}$ \\
\hline 13 & 567 & 60.24518 & -154.21787 & 80 & 65 & 85 & $\begin{array}{l}\text { Camel's Hump on } \\
\text { shore of Lake Clark ca. } \\
10 \mathrm{~km} \text { NE of Port } \\
\text { Alsworth }\end{array}$ & $\begin{array}{l}\text { Cliff face and } \\
\text { lakeshore rocks }\end{array}$ \\
\hline 13 & 571 & 60.37672 & -153.93924 & 80 & 68 & 99 & $\begin{array}{l}\text { Shore of Lake Clark } \\
\text { ca. } 30 \mathrm{~km} \mathrm{NE} \mathrm{of} \mathrm{Port} \\
\text { Alsworth, W of } \\
\text { Hatchet Point }\end{array}$ & $\begin{array}{l}\text { Marble cliffs and } \\
\text { talus by lakeshore }\end{array}$ \\
\hline 13 & 578 & 60.37572 & -153.94480 & 80 & 35 & 36 & $\begin{array}{l}\text { Shore of Lake Clark, } \\
\text { stop 2, W of Hatchet } \\
\text { Point }\end{array}$ & $\begin{array}{l}\text { Dark } \\
\text { noncalcareous } \\
\text { outcrops, } \\
\text { lakeshore cliffs }\end{array}$ \\
\hline 15 & 583 & 60.08131 & -152.62481 & 910 & 74 & 104 & $\begin{array}{l}\text { Summit of Slope } \\
\text { Mountain, overlooking } \\
\text { Tuxedni Channel }\end{array}$ & $\begin{array}{l}\text { Rocky ridge, } \\
\text { alpine tundra }\end{array}$ \\
\hline
\end{tabular}


Appendix 1 Continued.

\begin{tabular}{|c|c|c|c|c|c|c|c|c|}
\hline $\begin{array}{c}\text { Site } \\
\text { group }\end{array}$ & $\begin{array}{l}\text { Waypoint } \\
\text { cluster }\end{array}$ & Latitude & Longitude & $\begin{array}{c}\text { Elev. } \\
\text { m }\end{array}$ & $\begin{array}{c}\text { Species } \\
\text { count }\end{array}$ & $\begin{array}{l}\text { Specimens } \\
\text { IDd to } \\
\text { species }\end{array}$ & Location & Habitat \\
\hline & & & & & & & $\begin{array}{l}\text { Lake Clark } \\
\text { National Park }\end{array}$ & \\
\hline 16 & 597 & 60.00000 & -152.79253 & 655 & 49 & 60 & $\begin{array}{l}\text { Shoulder of basin on } \mathrm{E} \\
\text { side of Saddle } \\
\text { Mountain }\end{array}$ & $\begin{array}{l}\text { alpine tundra and } \\
\text { shrub thickets }\end{array}$ \\
\hline 17 & 606 & 60.23806 & -152.95673 & 600 & 73 & 93 & $\begin{array}{l}\text { Shoulder of mountain } \\
\text { overlooking Tuxedni } \\
\text { Bay }\end{array}$ & $\begin{array}{l}\text { alpine tundra with } \\
\text { noncalcareous } \\
\text { outcrops and } \\
\text { shrub thickets }\end{array}$ \\
\hline 18 & 619 & 60.15208 & -152.94970 & 770 & 43 & 48 & $\begin{array}{l}\text { Saddle on ridge near } \\
\text { headwaters of Johnson } \\
\text { River }\end{array}$ & $\begin{array}{l}\text { Alpine tundra, } \\
\text { noncalcareous } \\
\text { rock with small } \\
\text { calcareous } \\
\text { inclusions }\end{array}$ \\
\hline 14 & 620 & 59.87077 & -153.09098 & 4 & 131 & 272 & $\begin{array}{l}\text { Near Chinitna Ranger } \\
\text { Station on north side } \\
\text { of Chinitna Bay }\end{array}$ & $\begin{array}{l}\text { Picea forest on } \\
\text { low bench above } \\
\text { ocean }\end{array}$ \\
\hline 19 & 993 & 59.87423 & -153.07143 & 4 & 33 & 42 & $\begin{array}{l}\text { near mouth of Horn } \\
\text { Creek east of Chinitna } \\
\text { Ranger Station }\end{array}$ & $\begin{array}{l}\text { riparian Picea - } \\
\text { Populus forest }\end{array}$ \\
\hline 20 & 629 & 59.88357 & -153.03139 & 2 & 17 & 17 & $\begin{array}{l}\text { Shore of Chinitna Bay, } \\
\text { ca. } 4 \mathrm{~km} \text { ENE of } \\
\text { Chinitna Ranger } \\
\text { Station }\end{array}$ & $\begin{array}{l}\text { Sandstone } \\
\text { boulders on } \\
\text { shoreline }\end{array}$ \\
\hline 21 & 630 & 59.88044 & -153.04927 & 8 & 36 & 44 & $\begin{array}{l}\text { Shore of Chinitna Bay, } \\
\text { ca. } 3 \mathrm{~km} \text { ENE of } \\
\text { Chinitna Ranger } \\
\text { Station }\end{array}$ & $\begin{array}{l}\text { Grove of twisted } \\
\text { Populus } \\
\text { balsamifera on } \\
\text { sloped shoreline }\end{array}$ \\
\hline 22 & 634 & 59.87128 & -153.09395 & 4 & 16 & 21 & $\begin{array}{l}250 \mathrm{~m} \text { NE of Chinitna } \\
\text { Bay Ranger Station, } \\
\text { near site of } \\
\text { prehistorical pit houses }\end{array}$ & $\begin{array}{l}\text { Picea - Betula } \\
\text { forest }\end{array}$ \\
\hline
\end{tabular}

